Nevada

Environmental

Restoration

Project

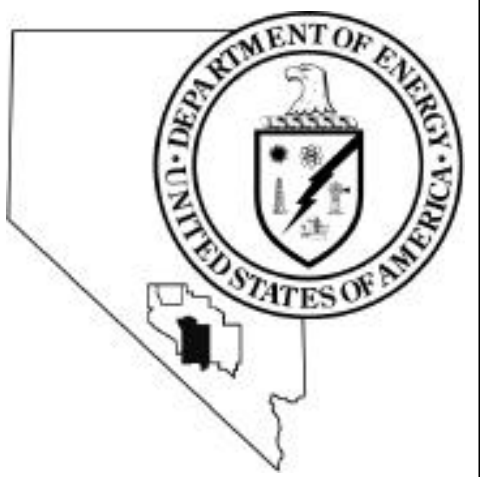

Corrective Action Investigation Plan for Corrective Action Unit 143:

Area 25 Contam inated W aste Dum PS, $\mathrm{N}$ evada Test $\mathrm{S}$ ite, $\mathrm{N}$ evada

Controlled Copy $\mathrm{N} 0$.:

Revision N 0.: 1

J une 1999

Approved for public release; further dissemination unlimited.

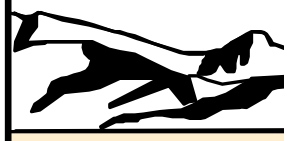

Environm ental Restoration

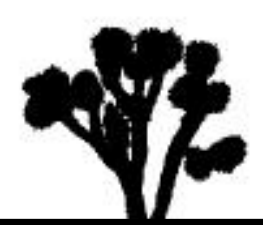

Division 
Available to the public from -

U.S. Department of Commerce

National Technical Information Service

5285 Port Royal Road

Springfield, VA 22161

(703) 487-4650

Available electronically at http://www.doe.gov/bridge. Available to U.S. Department of Energy and its contractors in paper from -

U.S. Department of Energy

Office of Scientific and Technical Information

P.O. Box 62

Oak Ridge, TN 37831-0062

(423) 576-8401

Reference here in to any specific commercial product, process, or service by trade name, trademark, manufacturer, or otherwise, does not necessarily constitute or imply its endorsement, recommendation, or favoring by the United States Government or any agency thereof or its contractors or subcontractors. 


\title{
CORRECTIVE ACTION INVESTIGATION PLAN FOR CORRECTIVE ACTION UNIT 143: AREA 25 CONTAMINATED WASTE DUMPS, NEVADA TEST SITE, NEVADA
}

\author{
DOE Nevada Operations Office \\ Las Vegas, Nevada
}

Controlled Copy No.:

Revision No.: 1

June 1999

Approved for public release; further dissemination unlimited. 


\section{CORRECTIVE ACTION INVESTIGATION PLAN FOR CORRECTIVE ACTION UNIT 143: AREA 25 CONTAMINATED WASTE DUMPS, NEVADA TEST SITE, NEVADA}

Approved by:

Date: $\quad 6 / 28 / 99$

Janet Appenzeller-Wing, Project Manager

Industrial Sites Project

Approved by: Signature Approved

Date: $\quad 6 / 28 / 99$

Runore C. Wycoff, Division Director Environmental Restoration Division 


\section{Table of Contents}

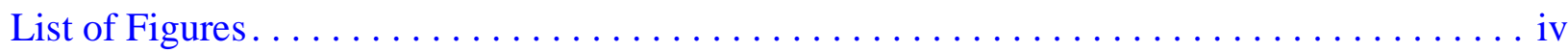

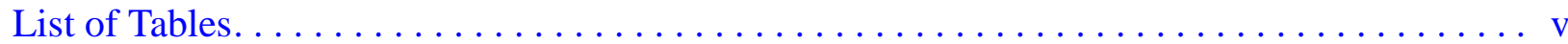

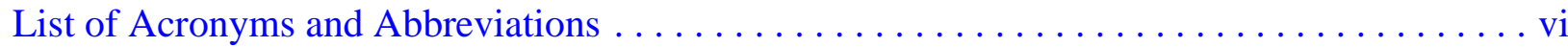

Executive Summary . . . . . . . . . . . . . . . . . . . . . . . ES-1

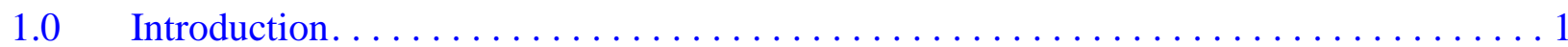

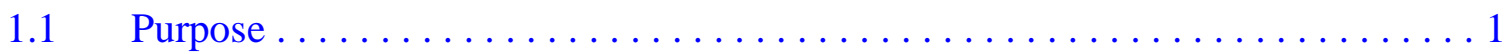

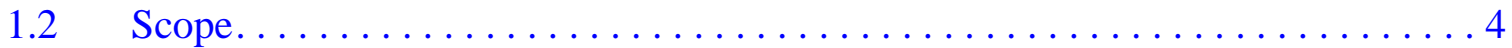

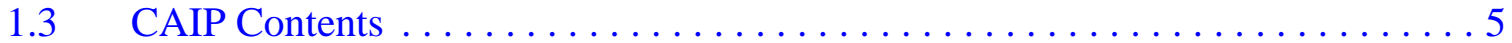

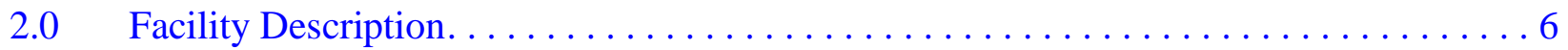

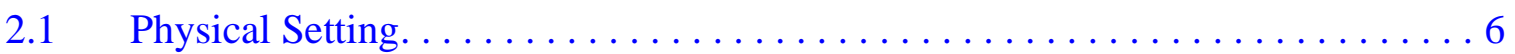

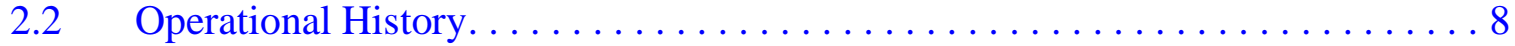

2.2.1 Operational History for R-MAD CWD $\# 1 \ldots \ldots \ldots \ldots \ldots \ldots \ldots \ldots$

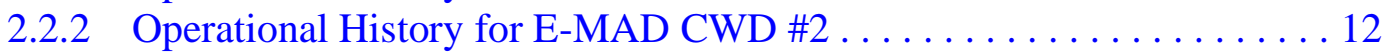

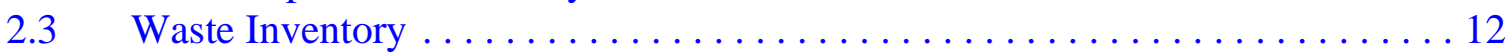

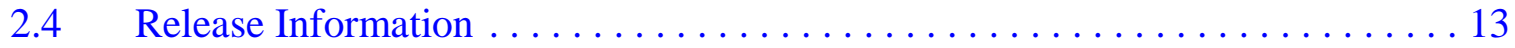

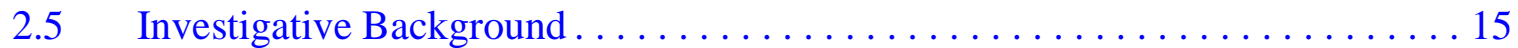

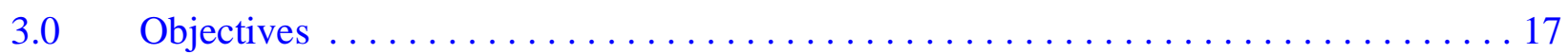

3.1 Conceptual Site Model . . . . . . . . . . . . . . . . . . . . 17

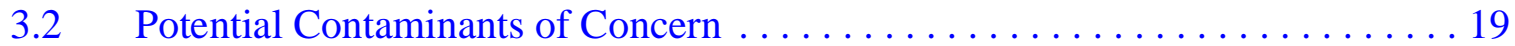

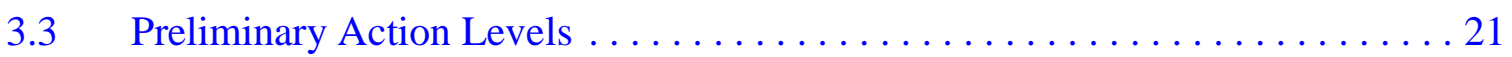

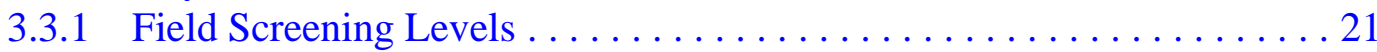

3.3 .2 Field Analyses. . . . . . . . . . . . . . . . . . . . 21

3.3.3 Chemical Preliminary Action Levels . . . . . . . . . . . . . . 22

3.3.4 Radiological Preliminary Action Levels. . . . . . . . . . . . . . . . 22

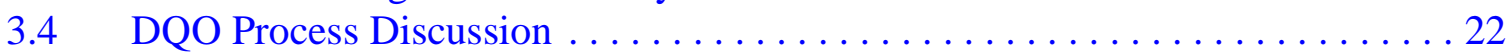

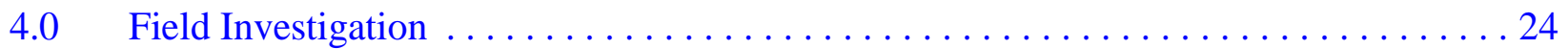

$4.1 \quad$ Technical Approach . . . . . . . . . . . . . . . . . . . . 25

4.1 .1 Geophysical Investigation. . . . . . . . . . . . . . . . 26

4.1.1.1 R-MAD Geophysical Results Summary . . . . . . . . . . . . 27

4.1.1.2 E-MAD Geophysical Results Summary. . . . . . . . . . . . . . 27

4.1 .2 Cone Penetrometer Testing. . . . . . . . . . . . . . . . . . . . . . 31

4.1 .3 In Situ Sampling and Field Analyses . . . . . . . . . . . . . . 32

4.1.4 Environmental Soil Samples. . . . . . . . . . . . . . . . . . . . . 33

4.1.5 Geotechnical Samples. . . . . . . . . . . . . . . . . . . . 34

4.1 .6 Background Samples ... . . . . . . . . . . . . . . . . . . . . . 34

4.1 .7 Quality Control Samples. . . . . . . . . . . . . . . . . . . . . . 34 


\section{Table of Contents (Continued)}

$5.0 \quad$ Waste Management. . . . . . . . . . . . . . . . . . . . . . . . . . 36

$5.1 \quad$ Waste Minimization . . . . . . . . . . . . . . . . . . . . . . . . . . 36

$5.2 \quad$ Potential Waste Streams .................................. 37

$5.3 \quad$ Investigation-Derived Waste Management $\ldots \ldots \ldots \ldots \ldots \ldots \ldots \ldots \ldots \ldots \ldots \ldots$

5.3 .1 Sanitary Wastes. ................................ 37

5.3.2 Low-Level Radioactive Waste . . . . . . . . . . . . . . . . . . . 38

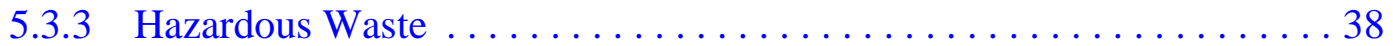

5.3 .4 Mixed Wastes ............................. 40

$6.0 \quad$ Duration and Records Availability . . . . . . . . . . . . . . . . . . . . 41

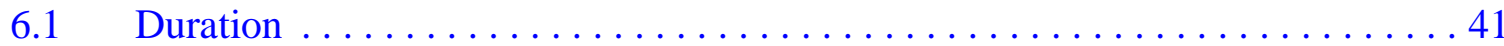

$6.2 \quad$ Records Availability ............................. 41

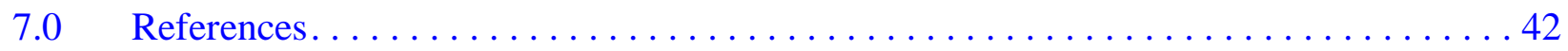

Appendix A - Data Quality Objectives for Corrective Action Investigation Plan for Corrective Action Unit 143

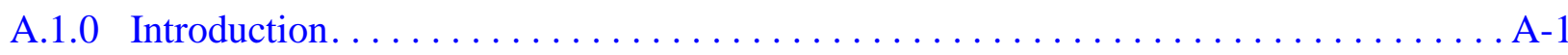

A.1.1 Problem Statement . . . . . . . . . . . . . . . . . . . . . . . . . . A- 1

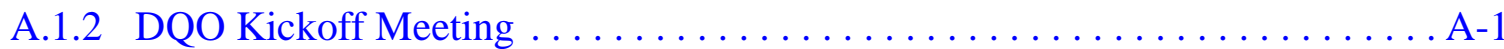

A.2.0 Conceptual Site Model . . . . . . . . . . . . . . . . . . . . . . . . A-3

A.3.0 Contaminants of Concern . . . . . . . . . . . . . . . . . . . . . . . . . A -6

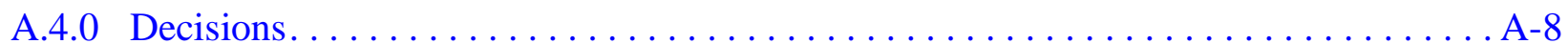

A.4.1 Decisions................................ A-8

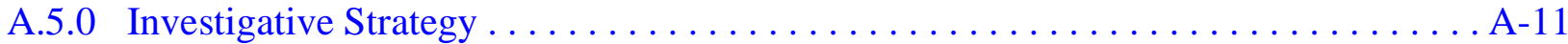

A.6.0 Decision Rules . . . . . . . . . . . . . . . . . . . . . . . . . . . . . . . . . . . . . . A-14

A.7.0 Decision Error. .................................. A-16

A.8.0 References...................................... A-17

Appendix B - Project Organization

B.1.0 Project Organization ........................................ 


\section{Table of Contents (Continued)}

\section{Appendix C - Historic Drawings}

C.1.0 Historic Drawings For CWD \#1 and CWD \#2 ................. C-1

Appendix D - Response to NDEP Comments 


\section{List of Figures}

Number

1-1 Nevada Test Site Location Map $\ldots \ldots \ldots \ldots \ldots \ldots \ldots \ldots \ldots \ldots \ldots \ldots \ldots \ldots \ldots \ldots$

1-2 R-MAD/E-MAD Locations at the Nevada Test Site $\ldots \ldots \ldots \ldots \ldots \ldots$

2-1 R-MAD/E-MAD Local Topography and Surface Water Drainage Patterns . . . . . 7

2-2 R-MAD Operational History at CWD $\# 1 \ldots \ldots \ldots \ldots \ldots \ldots \ldots \ldots \ldots \ldots$

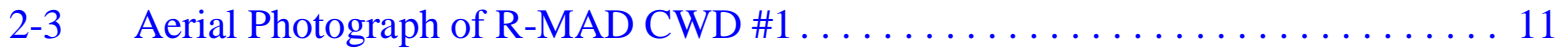

2-4 Photograph of Burial Trench R-MAD West Trench at CWD \#1 $\ldots \ldots \ldots \ldots 13$

2-5 Aerial Photograph of E-MAD . . . . . . . . . . . . . . . . . . . . . . . 14

3-1 Dry Washes in the Vicinity of R-MAD CWD $\# 1 \ldots \ldots \ldots \ldots \ldots \ldots \ldots \ldots$

4-1 R-MAD (CWD \#1) Geophysical Survey Areas ................... 28

4-2 R-MAD East and West Geophysical Anomalies and Approximate Borehole Locations . . . . . . . . . . . . . . . . . . . . . . . . . . . . . . . . . . . . . . 29

4-3 E-MAD Geophysical Anomaly and Approximate Borehole Locations . . . . . . . . . 30

C.1-1 MAD Dump Area Expansion Trestle Plan \& Profile................. C-2

C.1-2 Proposed Addition to MAD Bldg. Dump Area $\ldots \ldots \ldots \ldots \ldots \ldots \ldots$ C-3

C.1-3 Burial Pit R-MAD Hot Dump. ....................... C-4

C.1-4 Radioactive Waste Disposal Area E-MAD $\ldots \ldots \ldots \ldots \ldots \ldots \ldots$ C-5 


\section{List of Tables}

Number

2-1 List of Detected Radionuclides in Soil Samples Collected Prior to $1986 \ldots \ldots 16$

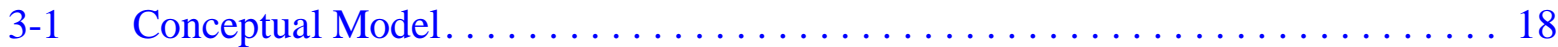

4-1 Laboratory Analytical Requirements . . . . . . . . . . . . . 24

4-2 Geotechnical Analyses . . . . . . . . . . . . . . . . . 34

A.1-1 DQO Meeting Participants $\ldots \ldots \ldots \ldots \ldots \ldots \ldots \ldots \ldots \ldots \ldots \ldots \ldots \ldots \ldots \ldots$

A.3-1 Contaminants of Potential Concern $\ldots \ldots \ldots \ldots \ldots \ldots \ldots \ldots \ldots \ldots \ldots$

A.4-1 General Strategies . . . . . . . . . . . . . . . . . . . . . A-9

A.6-1 CAU Subsurface Specific Decision Points and Rules . . . . . . . . . . . . A-15 


\section{List of Acronyms and Abbreviations}

\begin{tabular}{|c|c|}
\hline AEC & U.S. Atomic Energy Commission \\
\hline bgs & Below ground surface \\
\hline CADD & Corrective Action Decision Document \\
\hline CAIP & Corrective Action Investigation Plan \\
\hline CAS & Corrective Action Site(s) \\
\hline CAU & Corrective Action Unit(s) \\
\hline CFR & Code of Federal Regulations \\
\hline $\mathrm{cm}$ & Centimeter(s) \\
\hline${ }^{60} \mathrm{Co}$ & Cobalt -60 \\
\hline $\mathrm{COPC}$ & Contaminant(s) of potential concern \\
\hline CPT & Cone Penetrometer \\
\hline${ }^{137} \mathrm{Cs}$ & Cesium-137 \\
\hline CWD & Contaminated Waste Dump(s) \\
\hline D\&D & Decontamination and decommissioning \\
\hline DOE & U.S. Department of Energy \\
\hline $\mathrm{DOE} / \mathrm{NV}$ & U.S. Department of Energy, Nevada Operations Office \\
\hline DOT & U.S. Department of Transportation \\
\hline DQO & Data Quality Objective(s) \\
\hline E-MAD & Engine Maintenance Assembly and Disassembly Facility \\
\hline EPA & U.S. Environmental Protection Agency \\
\hline${ }^{152} \mathrm{Eu}$ & Europium-152 \\
\hline FID & Flame ionization detector \\
\hline FFACO & Federal Facility Agreement and Consent Order \\
\hline $\mathrm{ft}$ & Foot (feet) \\
\hline GC/MS & Gas chromatograph/mass spectrometer \\
\hline GPR & Ground penetrating radar \\
\hline
\end{tabular}




\section{List of Acronyms and Abbreviations (Continued)}

HASP

IDW

in.

INEEL

ITLV

$\mathrm{km}^{2}$

LANL

LLW

$\mathrm{m}$

$\mathrm{m}^{3}$

$\mathrm{mi}^{2}$

MS/MSD

NAC

NAS

NASA

${ }^{94} \mathrm{Nb}$

NDEP

NEPA

NRDA

NRDS

NTS

NTSWAC

PAL

PID

PPE

ppm
Health and Safety Plan

Investigation-derived waste

$\operatorname{Inch}(\mathrm{es})$

Idaho National Environmental Engineering Laboratory

IT Corporation, Las Vegas Office

Square kilometer(s)

Los Alamos National Laboratory

Low-level radioactive waste

Meter(s)

Cubic meter(s)

Square mile(s)

Matrix spike and matrix spike duplicate

Nevada Administrative Code

National Academy of Sciences

National Aeronautic and Space Administration

Niobium-94

Nevada Division of Environmental Protection

National Environmental Policy Act

Nevada Research and Development Area

Nuclear Rocket Development Station

Nevada Test Site

Nevada Test Site Waste Acceptance Criteria

Preliminary action level(s)

Photoionization detector

Personal protective equipment

Part(s) per million 


\section{List of Acronyms and Abbreviations (Continued)}

\begin{tabular}{|c|c|}
\hline${ }^{239} \mathrm{Pu}$ & Plutonium-239 \\
\hline QA & Quality assurance \\
\hline QAPP & Quality Assurance Project Plan \\
\hline QC & Quality control \\
\hline${ }^{226} \mathrm{Ra}$ & Radium-226 \\
\hline R-MAD & Reactor Maintenance Assembly and Disassembly Facility \\
\hline RCRA & Resource Conservation and Recovery Act \\
\hline REECo & Reynolds Electrical \& Engineering Co., Inc. \\
\hline RPD & Relative percent difference \\
\hline SAIC & Science Applications International Corporation \\
\hline SSHASP & Site-Specific Health and Safety Plan \\
\hline SNPO & Space Nuclear Propulsion Office \\
\hline${ }^{90} \mathrm{Sr}$ & Strontium-90 \\
\hline SVOC & Semivolatile organic compound(s) \\
\hline TID & Tamper-indicating device(s) \\
\hline TNT & Transient Nuclear Test \\
\hline TPH & Total petroleum hydrocarbon(s) \\
\hline TRU & Transuranic waste \\
\hline${ }^{234} \mathrm{U}$ & Uranium-234 \\
\hline${ }^{235} \mathrm{U}$ & Uranium-235 \\
\hline USGS & U.S. Geological Survey \\
\hline VOC & Volatile organic compound(s) \\
\hline $\mathrm{yd}^{3}$ & Cubic yard(s) \\
\hline
\end{tabular}




\section{Executive Summary}

The Corrective Action Investigation Plan for Corrective Action Unit 143, Area 25 Contaminated Waste Dumps, has been developed in accordance with the Federal Facility Agreement and Consent Order (FFACO, 1996) that was agreed to by the U.S. Department of Energy, Nevada Operations Office; the State of Nevada Division of Environmental Protection; and the U.S. Department of Defense. Corrective Action Unit 143 consists of two Corrective Action Sites: 25-23-09, Contaminated Waste Dump \#1 at the Reactor Maintenance Assembly and Disassembly Facility (R-MAD) and 25-23-03, Contaminated Waste Dump \#2 at the Engine Maintenance Assembly and Disassembly Facility (E-MAD).

Solid radioactive wastes were disposed of at both waste dumps. At Contaminated Waste Dump \#1, solid radioactive wastes were disposed of in five separate areas: a waste dump below a railroad trestle southeast of R-MAD facility, two sites west of the railroad berm, a mound in the southwest corner of R-MAD east, six trenches in R-MAD west, and a pit south of R-MAD west. At Contaminated Waste Dump \#2, solid radioactive wastes were disposed of in a single trench located outside the southwestern corner of the facility.

Based on the site history and other information collected to support the Data Quality Objectives process, a conceptual site model for the Corrective Action Unit was developed as follows:

- The landfill disposal areas contain solid wastes contaminated with radioactivity.

- Radionuclides are the primary constituents of concern and are located in disposal areas.

- Vertical and lateral migration of contaminants of potential concern is not likely.

- If contaminant migration is has occurred, it will be limited to the soil beneath the Contaminated Waste Dump disposal areas.

A more detailed conceptual model is presented in Section 3.0 of this investigation plan. The conceptual model serves as the basis for the sampling strategy. 
Geophysics have been completed to determine the location and extent of the waste disposal areas. The site investigation includes the following activities:

- Performing Cone Penetrometer (CPT) testing within and/or near radioactive solid waste disposal sites

- Conducting field analyses for radiological constituents and volatile organic compounds with the instruments in the CPT

- Collecting confirmatory surface and subsurface environmental soil samples using CPT and/or sonic drilling

- Collecting geotechnical subsurface soil samples

- Collecting background and subsurface soil samples

- Collecting required quality control samples

- $\quad$ Surveying sampling locations and the Contaminated Waste Dumps

Samples will be collected for laboratory analysis at selected sites. Additional sampling and analytical details are presented in Section 4.0 of this investigation plan. Details of the waste management strategy for the Corrective Action Unit are included in Section 5.0.

Under the Federal Facility Agreement and Consent Order, this Corrective Action Investigation Plan will be submitted to the Nevada Division of Environmental Protection for approval. The field work will be conducted following approval of the plan. The results of the field investigation will support a defensible evaluation of corrective action alternatives in the Corrective Action Decision Document. 


\subsection{Introduction}

This Corrective Action Investigation Plan (CAIP) has been developed in accordance with the Federal Facility Agreement and Consent Order (FFACO) that was agreed to by the U.S. Department of Energy, Nevada Operations Office (DOE/NV); the State of Nevada Division of Environmental Protection (NDEP); and the U.S. Department of Defense (FFACO, 1996). The CAIP is a document that provides or references all of the specific information for investigation activities associated with Corrective Action Units (CAUs) or Corrective Action Sites (CASs). A CAU may consist of one or more CASs grouped together based on geography, technical similarity, or agency responsibility for the purpose of determining corrective actions. This CAIP provides specific information related to investigation activities associated with CAU 143 which consists of CASs 25-23-03 and 25-23-09 (FFACO, 1996; Liebendorfer, 1998).

This CAIP contains the sampling objectives and criteria for conducting corrective action investigation activities under CAU 143. The CAU consists of two Contaminated Waste Dumps (CWDs) that are located in Area 25 at the Nevada Test Site (NTS) (Figure 1-1). Area 25 is located in the southwestern corner of the NTS, which is approximately 130 kilometers ( 80 miles) northwest of Las Vegas, Nevada, the closest major population center. Contaminated Waste Dump \#1 (CWD \#1) is located at the Reactor Maintenance Assembly and Disassembly Facility (R-MAD) (CAS No. 25-23-09), and Contaminated Waste Dump \#2 (CWD \#2) is located at the Engine Maintenance Assembly and Disassembly Facility (E-MAD) (CAS No. 25-23-03) (Figure 1-2). Both facilities were originally constructed for the Nuclear Rocket Development Station (NRDS) which was administered by the Space Nuclear Propulsion Office (SNPO) (AEC, 1969). Nuclear reactors and engines were developed, assembled, tested, and then disassembled for further testing and evaluation. While specific records related to facility disposal practices are limited, weekly reports and NRDS procedures indicate that the disassembled rocket engine parts were disposed of in the individual CWDs of each facility.

\subsection{Purpose}

Solid radioactive wastes were disposed of at both waste dumps. At CWD \#1, solid radioactive wastes were disposed of in five separate areas: below a railroad trestle southeast of the R-MAD facility, two 


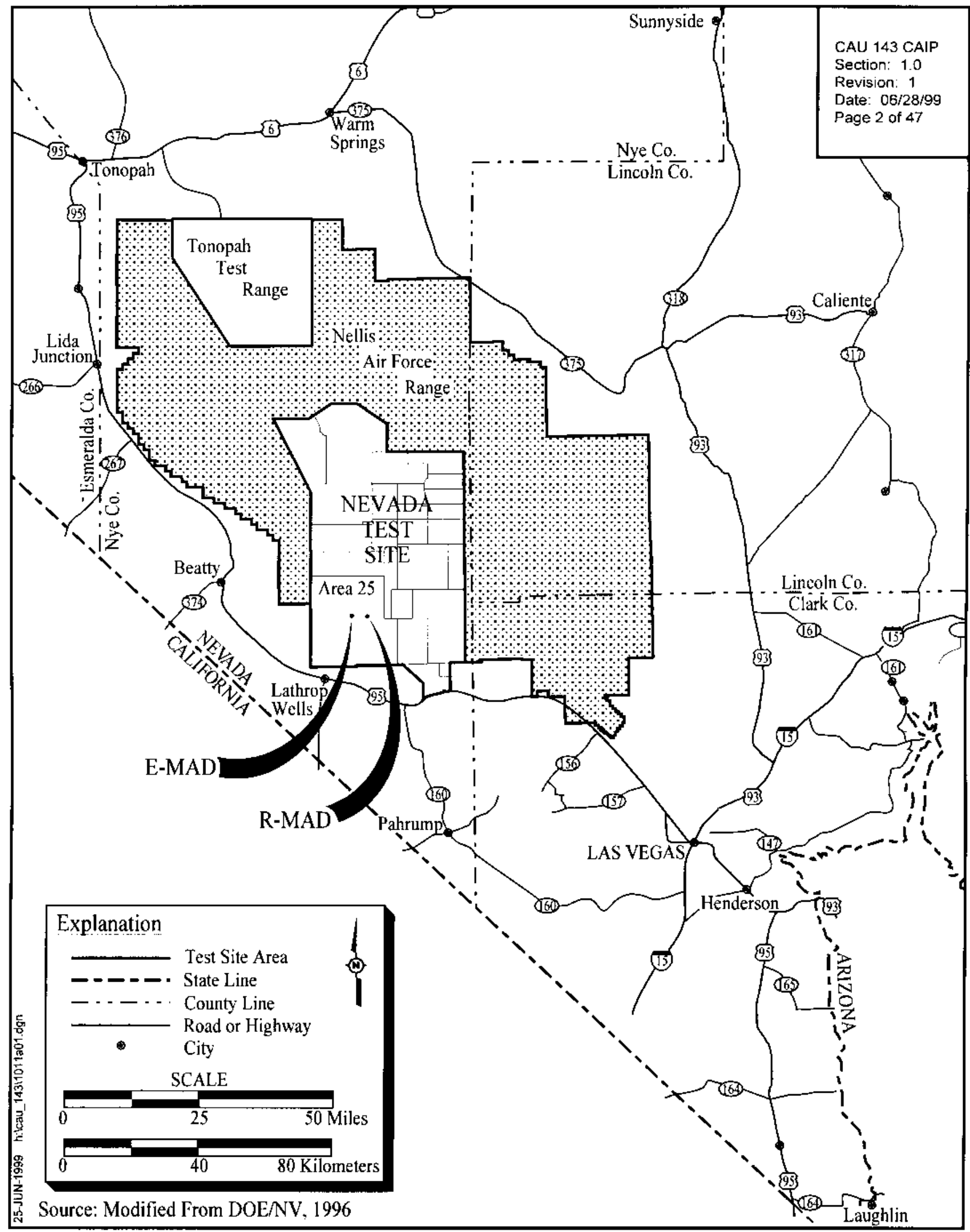

Figure 1-1

Nevada Test Site Location Map 


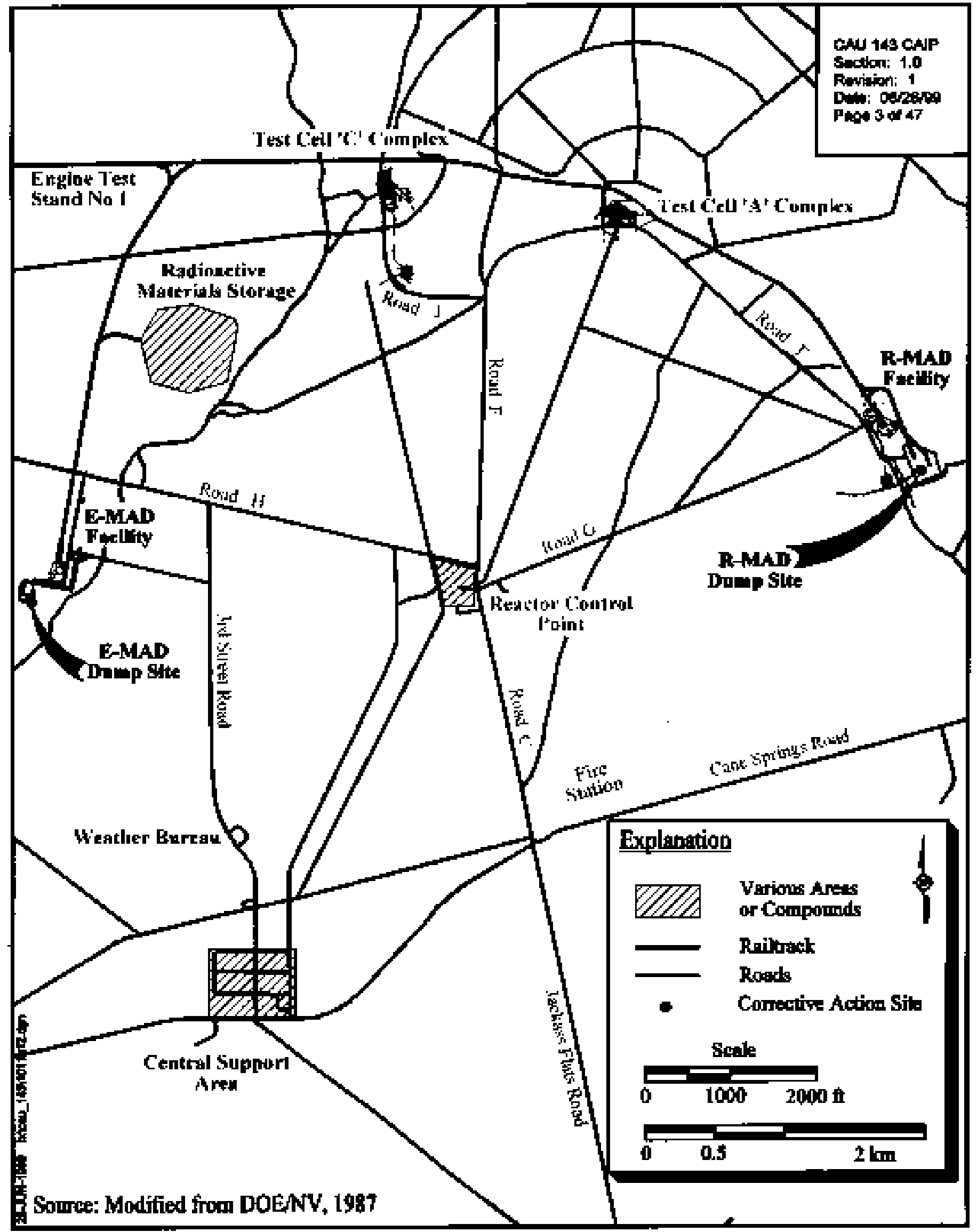


pits between and west of the railroad berm in R-MAD east, a mound in the southwest corner of R-MAD east, six trenches inside R-MAD west, and a pit south of R-MAD west. At the E-MAD facility, solid radioactive wastes were disposed of in a single trench located outside the southwestern corner of the facility (CWD \#2). Due to the unregulated disposal activities commonly associated with landfill operations in the late 1950s through the late 1970s, it is necessary to conduct a corrective action investigation to:

- Identify the presence and nature of contaminants of potential concern (COPCs).

- Determine the vertical and lateral extent of fill materials and COPCs.

- Provide sufficient information and data to develop and evaluate appropriate corrective actions for the CAU.

This CAIP was developed using the U.S. Environmental Protection Agency (EPA) Data Quality Objectives (DQOs) (EPA, 1994) process to clearly define the goals for collecting and using environmental data, and to design a data collection program that will satisfy these goals and uses. A series of DQO scoping meetings were held prior to preparation of this plan; a brief summary of the DQOs is presented in Section 3.4. A more detailed summary of the DQO process and results are included in Appendix A.

\subsection{Scope}

Geophysical survey results (SAIC, 1998 and 1999) will be used to optimize and help direct the scope of work to be performed under this CAIP. The results of the preliminary geophysical assessment support the site assumptions for each CWD, as presented during the DQO process (Appendix A). The scope of this CAIP is to characterize the nature and extent of solid radioactive wastes and hazardous wastes, if any, that were disposed of at the CWDs and to obtain data sufficient to support selection of a corrective action for the CAU. The following tasks must be accomplished to address this problem statement:

- Use geophysical surveys and historical document review to select CWD areas and to determine vertical extent of buried wastes, as appropriate.

- Use Cone Penetrometer (CPT) to collect in situ field screening data and geotechnical, gamma radiation, and volatile organic compound field analyses to define the nature and extent of the 
waste in the CWDs and, more importantly, any migration of contaminants that may have occurred.

- Collect soil samples from selected locations for off-site laboratory analysis of environmental and geotechnical parameters using the CPT and/or sonic drilling.

\subsection{CAIP Contents}

Section 1.0 of this CAIP provides an introduction to this project, including the purpose and scope for this corrective action investigation. The remainder of the document details the investigation strategy and complies with FFACO (1996) requirements that CAIPs address. This CAIP contains the following elements:

- Management

- Technical aspects

- Quality assurance

- Health and safety

- Public involvement

- Field sampling

- Waste management

The managerial aspects of this project are discussed in the DOE/NV Project Management Plan (DOE/NV, 1994) and the site-specific Field Management Plan (to be developed prior to field activities). In addition, Appendix B to this document provides information regarding the project organization. The technical aspects of this CAIP are contained in Sections 3.0 and 4.0 and in the DQO summary presented in Appendix A. General field and laboratory quality assurance and quality control (QC) issues, including collection of QC samples, are presented in the Industrial Sites Quality Assurance Project Plan (QAPP) (DOE/NV, 1996b). The health and safety aspects of this project are documented in the Environmental Restoration Project Health and Safety Plan (HASP)

(DOE/NV, 1998) and will also be supplemented with a site-specific HASP (SSHASP) written prior to the start of field work. No CAU-specific public involvement activities are planned at this time; however, an overview of public involvement is documented in the "Public Involvement Plan" in Appendix V of the FFACO (1996). Field sampling activities are discussed in Section 4.0 and waste management issues are discussed in Section 5.0. The project schedule and records availability information for this CAIP are discussed in Section 6.0, and Section 7.0 provides a list of project references. 


\subsection{Facility Description}

There are two CASs currently under investigation for CAU 143. The first, CWD \#1 is located at the R-MAD facility (CAS No. 25-23-09), while CWD \#2 is located at the E-MAD facility (CAS No. 25-23-03). The R-MAD and E-MAD facilities originally constituted a portion of the NRDS in Area 25 at the NTS, and both CWDs primarily received solid radioactive wastes from discarded nuclear reactor or engine parts (IT, 1998). The R-MAD facility was decommissioned in January 1973 (DOE, 1980) and the E-MAD facility was decommissioned around 1972 (DOE/NV, 1997a).

\subsection{Physical Setting}

The CWDs are situated in Area 25 of the NTS which is located in Death Valley Basin Hydrogeographic Region of California and Nevada, as defined by Rush (1968) and the U.S. Geological Survey (USGS) (1978). More specifically, the CWDs are situated within the Fortymile Canyon, Jackass Flats hydrogeographic area of the Alkali Flat-Furnace Creek Ranch Subbasin. The hydrogeographic area is approximately 723 square kilometers $\left(\mathrm{km}^{2}\right)$ (279 square miles $\left.\left[\mathrm{mi}^{2}\right]\right)$ and receives, on average, approximately 13 centimeters $(\mathrm{cm})(5$ inches [in.]) of rainfall annually (DOE/NV, 1988c). Geographically, the CWDs are located within the Jackass Flats and Skull Mountain Quadrangles (USGS, 1983a and b) (Figure 2-1). Of some importance to characterizing the CWDs are topographic influences on the drainage of surface water resulting from significant rainfall events. Hydrogeologic conditions beneath the CWDs are less important to site characterization since individual disposal units were originally 3 to 6 meters $(\mathrm{m})$ (10 to $20 \mathrm{feet}[\mathrm{ft}])$ below grade, Quaternary alluvium is likely to reach depths of greater than $30 \mathrm{~m}(100 \mathrm{ft})$ below ground surface (bgs) (DOE/NV, 1988c), and the depth to groundwater is approximately $290 \mathrm{~m}$ (950 ft) bgs (DOE/NV, 1988c).

Although the region has a generally arid to semiarid climate with a high average annual potential evaporation, low average annual precipitation, and infrequent storms, surface runoff from rainfall events does occur. Surface runoff results from regional storms that mostly occur in winter and occasionally in fall and spring. Localized thunderstorms occur mostly during the summer months. 


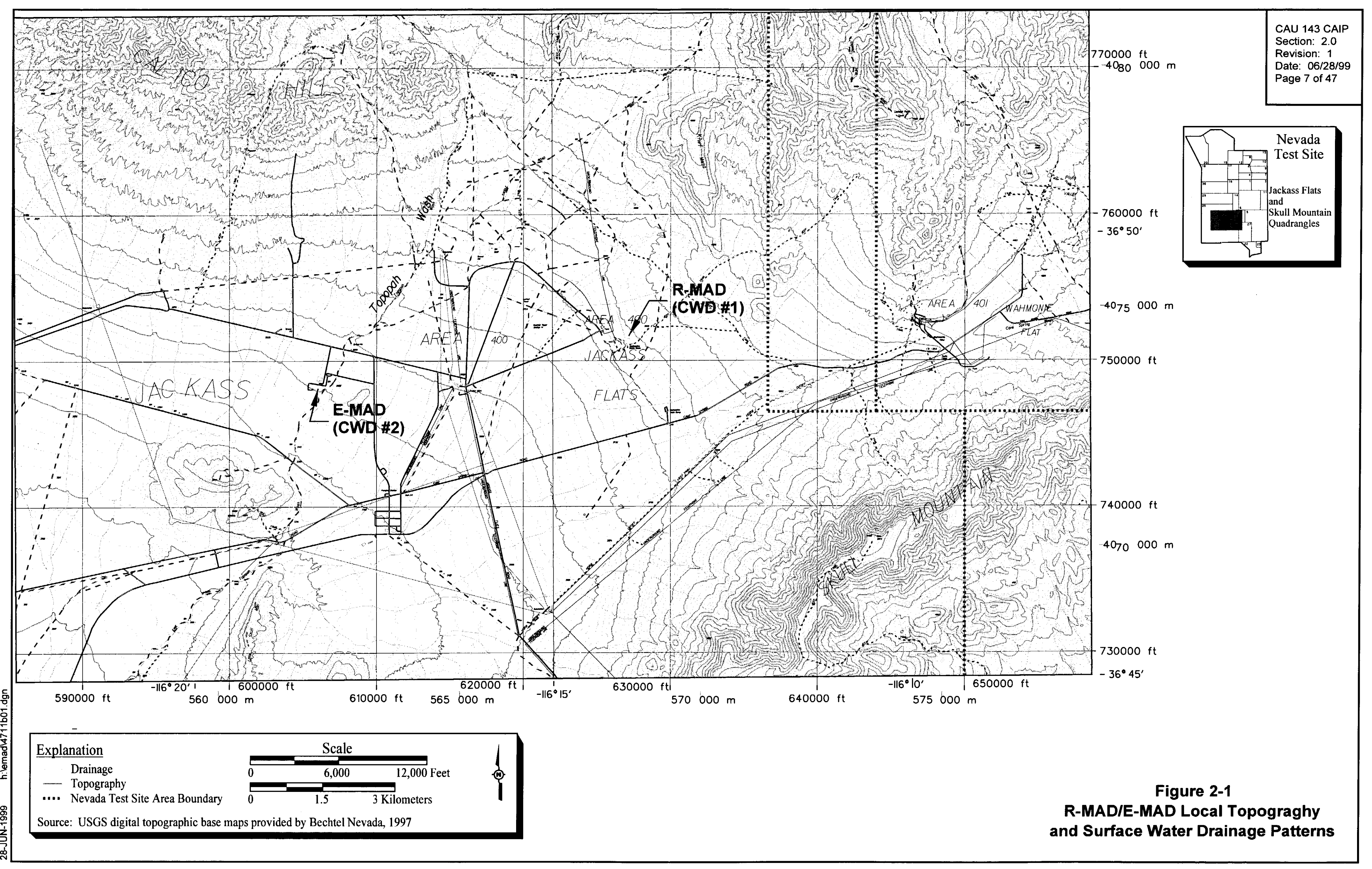


Quantitative data on rainfall, runoff, and evaporation for the area are not yet adequate to determine rainfall-runoff-recharge relations for individual storms, seasons, or years (DOE/NV, 1988c).

Dry washes provide channels that concentrate surface runoff. The dry washes, consequently, may be the principal sources of groundwater recharge to the area (DOE/NV, 1988c). There is no perennial streamflow in the region, but the closest major dry wash in the vicinity of the CWDs is the Topopah Wash which runs southwesterly through Jackass Flats to the middle of the south side of the NRDS approximately 1.5 kilometers (1 mile) south of E-MAD (Figure 2-1). As shown in Figure 2-1, the topographic relief in the vicinity of the R-MAD facility is relatively steep when compared to that of the E-MAD facility. Kiwi Mesa is immediately northeast and east of CWD \#1, and Skull Mountain is east and southeast of CWD \#1. Several minor dry washes in the vicinity of CWD \#1 drain west and southwest towards larger dry washes such as the Topopah Wash south and east of E-MAD.

\subsection{Operational History}

From 1959 through 1973, the U.S. Atomic Energy Commission (AEC) participated jointly with the U.S. National Aeronautics and Space Administration (NASA) in the development of nuclear rocket engines at the NTS. The AEC and NASA formed SNPO to oversee the project. These nuclear rocket engines were tested at the NRDS, now known as the Nevada Research and Development Area (NRDA), located in Area 25 at the NTS. During the rocket engine test program, significant quantities of radioactive material were produced.

The following operational histories for R-MAD and E-MAD are based on historical document review. Sources reviewed included historic records, historic analytical data, systems descriptions, plans and drawings, mass balance documentation, literature search, former employee interviews, and documented procedures. Process knowledge indicates that solid radioactive wastes were disposed of in the CWDs and liquid wastes were disposed of in the R-MAD and E-MAD leachfields (Fauver, 1986; Geary, 1998). 


\subsubsection{Operational History for R-MAD CWD \#1}

Between 1959 and 1979, CWD \#1 was used for the disposal of solid radioactive waste material from the R-MAD facility which was initially utilized for the assembly and disassembly of Kiwi Reactors (Fauver, 1986). The NRDS Master Plan states the following concerning CWD \#1 (AEC, 1969):

"The hot dump [CWD \#1] is used for the storage and cooling of used test cars, components and contaminated waste. The dump encompasses an area of 10 acres and is served by two spurs from the main railroad line. One spur ends in a trestle which permits remote dumping of contaminated waste from three dump cars into a pit under the trestle. The second spur ends in a depressed section of track where spent fuel is stored on hooded flatcars."

Figure 2-2 identifies major CWD \#1 activity areas identified from first-hand process knowledge of the facility (Geary, 1998). Solid radioactive wastes were transported via railroad from R-MAD to CWD \#1, located at the terminus of a railroad spur southeast of R-MAD. The waste materials were unloaded from the dump cars to either side of a trestle at the railroad terminus for CWD \#1. The

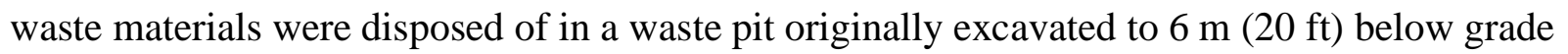
(Appendix C, Figure C.1-1 and Figure C.1-2) (BN, 1997). The waste pit was consistently backfilled with original soil to reduce radiation exposure to site workers. Consequently, the waste pit is currently composed of alternating layers of solid radioactive waste and original site soil taken from a dirt mound south of the waste pit. Rocks and boulders that were too large to return to the waste pit were stored at a spoils pile east of CWD \#1. Grossly contaminated materials were transported via dump cars to a decontamination facility prior to disposal at CWD \#1. Wastewater from the decontamination facility was discharged to a leachfield (CAU 262) near R-MAD (Fauver, 1986).

The second railroad spur is located east of the CWD \#1 disposal pit, surrounded on three sides by a soil berm used for shielding site workers from radioactive material. Radioactive material was stored on the eastern railroad spur until required for reuse by the R-MAD facility. After 1965, track from the eastern spur was removed, and the railroad spur was straightened from its previous S-shape (Figure 2-3).

Six trenches are located west of the trestle spur and the disposal pit. The trenches were identified in 1968 by Los Alamos Scientific Laboratory as the "Burial Pit R-MAD Hot Dump" (Appendix C, Figure C.1-3) (BN, 1997). For burial pits 1 through 4, the drawing indicates trench dimensions of 


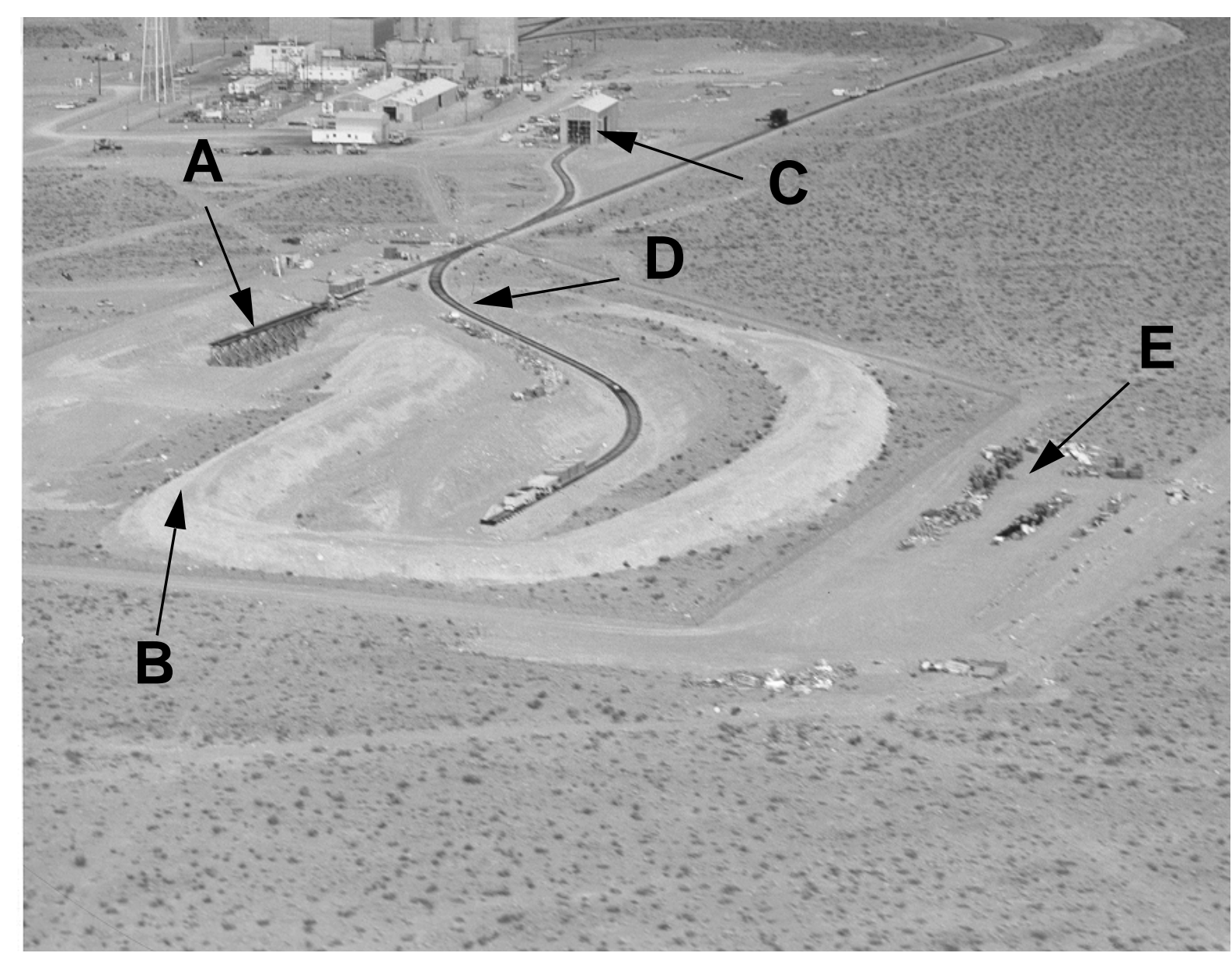

Source: EG\&G Photograph Number 6411720 taken in 1964 (EG\&G, 1964)

\section{Legend:}

A - Trestle Spur utilized for disposal of solid radioactive waste at either side of spur.

B - Soil berm utilized for shielding radioactive materials stored on eastern railroad spur.

C - Decontamination facility utilized to remove gross radioactivity from materials prior to their disposal in CWD \#1; decontamination liquids were discharged to R-MAD leachfield.

D - Eastern spur utilized for storage of radioactive materials at railroad track terminus.

E - Spoils pile utilized for storage of boulders removed during excavations at CWD \#1.

Legend source: Geary, 1998

Figure 2-2

R-MAD Operational History at CWD \#1 


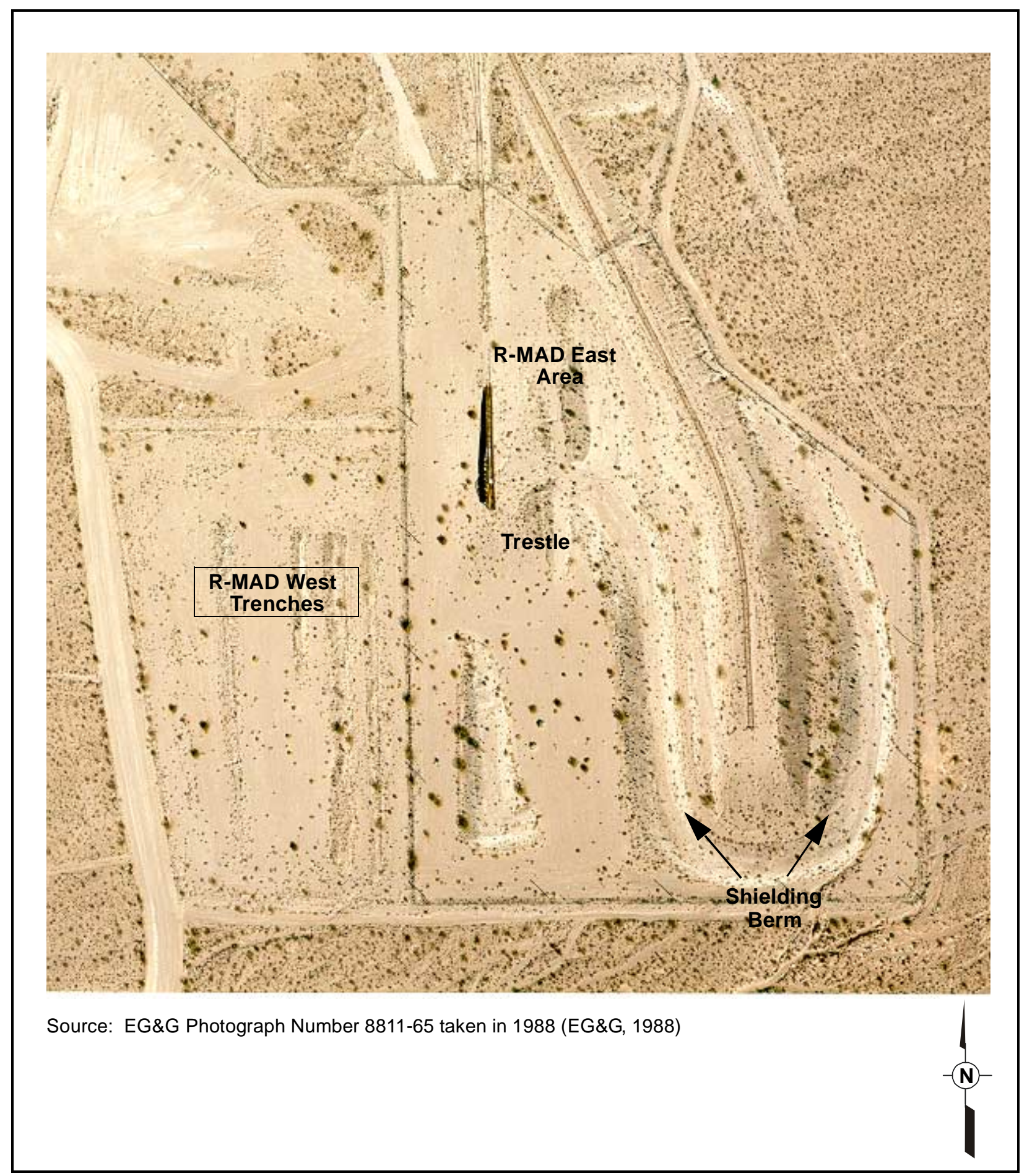

Figure 2-3 Aerial Photograph of R-MAD CWD \#1 
$3 \mathrm{~m} \times 3 \mathrm{~m} \times 122 \mathrm{~m}(10 \mathrm{ft} \times 10 \mathrm{ft} \times 400 \mathrm{ft})$. The drawing indicates the dimensions of the burial pits 5 and 6 trenches as $3 \mathrm{~m} \times 3 \mathrm{~m} \times 137 \mathrm{~m}$ (10 ft x $10 \mathrm{ft} \times 450 \mathrm{ft}$ ). Figure 2-3 depicts the locations of the trenches relative to the trestle spur and Figure 2-4 depicts waste in at least one disposal trench

\subsubsection{Operational History for E-MAD CWD \#2}

The E-MAD facility was designed and used for the assembly and preparation of nuclear engines for testing, the refurbishment of radioactive engines, and the disassembly and detailed post mortem inspection of test engines and components. Built in 1962, the facility was used for Project ROVER (the nuclear rocket program) until approximately 1973 when the program was canceled. Under Project ROVER, nuclear reactors and engines were developed, assembled, tested, and then disassembled for further testing and evaluation. While documentation related to facility disposal practices is limited, it is believed that only the disassembled rocket engine parts and other solid wastes were disposed of in the individual CWDs of each facility. The contaminated waste dumps received solid radioactive wastes including discarded nuclear reactor or engine parts. In 1978, the Fuel Demonstration Project set up operations at the E-MAD facility. All fuel cores were removed from the site, and the facility has been inactive since about 1989 (DRI, 1996). During the late 1960s, CWD \#2 was used to dispose of solid radioactive waste material from E-MAD (Appendix C, Figure C.1-4) (BN, 1997). Located $91 \mathrm{~m}$ (100 yards) south of the southwest corner of the E-MAD facility fence, CWD \#2 consists of a single trench which measures $3 \mathrm{~m}$ x $3 \mathrm{~m}$ x $60 \mathrm{~m}$ $(10 \mathrm{ft} \times 10 \mathrm{ft} \times 200 \mathrm{ft}$ ) (Figure 2-5). Engineering drawings and ground-level photos indicate that the pit was not filled to capacity. A mound of soil south of the waste trench contains original soil from the waste trench.

\subsection{Waste Inventory}

The COPCs were released directly to CWD surface and subsurface soils as a result of solid radioactive waste burial related to nuclear reactor and engine development. Buried wastes include rocket engine parts, test assembly parts, and scrape and clean up materials activated or contaminated in the form of activation products, mixed fission products, and potential fuel particles as contaminants. The exact amount and type of solid waste disposed of in the CWDs is unknown. 


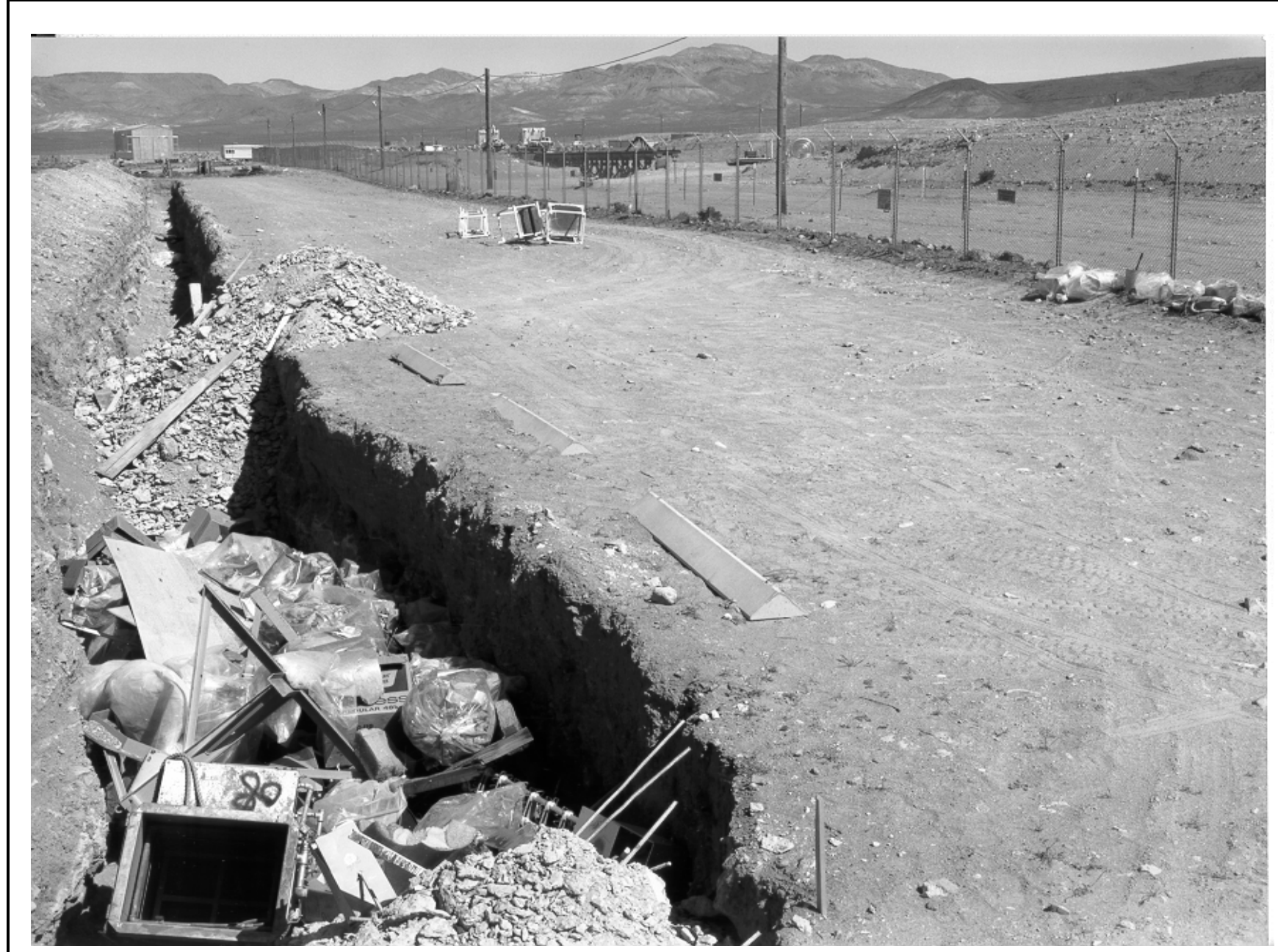

Source: EG\&G Photograph Number 664321 taken in 1966 (EG\&G, 1966)

\section{Figure 2-4}

\section{Photograph of Burial Trench R-MAD West Trench at CWD \#1}

\subsection{Release Information}

While liquid wastes were released to facility leachfields, migration of subsurface COPCs in the CWDs would result from the generation of leachate via natural processes (i.e., surface water infiltration). Migration of subsurface COPCs due to infiltration is assumed to be very minor due to the arid climate and the low permeabilities of the native soils. Release information related to the conceptual model for each CWD is further discussed in Section 3.1. 


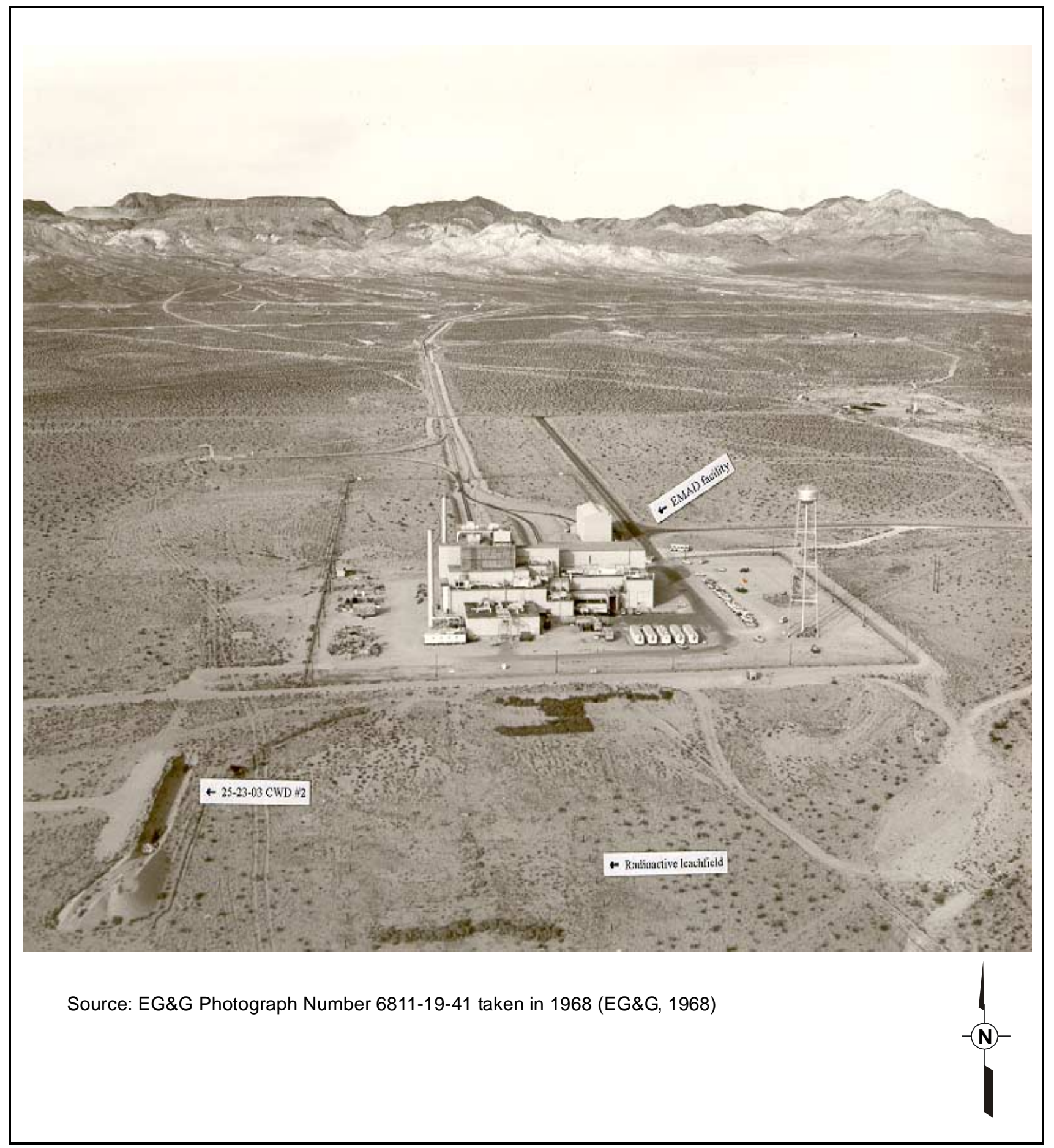

Figure 2-5

Aerial Photograph of E-MAD 


\subsection{Investigative Background}

In 1980, the R-MAD compound was decontaminated and decommissioned (D\&D). Equipment, scrap metal, and salvage materials were segregated into radioactive and nonradioactive lots. Clean materials were either incorporated in the NTS usage system, or excessed for sale to the public (DOE, 1980). During D\&D activities, 2,987 cubic meters $\left(\mathrm{m}^{3}\right)\left(3,904\right.$ cubic yards $\left.\left[\mathrm{yd}^{3}\right]\right)$ of equipment and $1,150 \mathrm{~m}^{3}\left(1,500 \mathrm{yd}^{3}\right)$ of soil were removed from the R-MAD Radioactive Material Storage Area. The resulting void was filled with clean soil and contoured to original surface grade

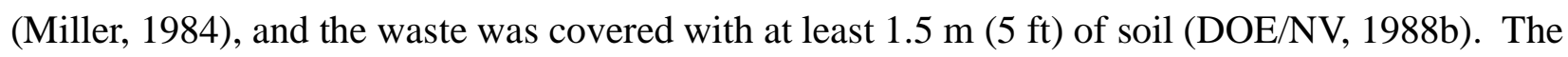
E-MAD facility was not included in the Area 25 cleanup of 1974-1983 (DOE/NV, 1988a).

Reynolds Electrical \& Engineering Company, Inc. (REECo) (1986) reported radiological results from soil samples collected at the R-MAD and E-MAD CWDs. The radiological results were from previously unreported data that were included in Appendix A of the REECo (1986) report. Soil sampling locations within the CWDs are unknown. Soil samples were collected at three locations at the R-MAD CWD and at two locations at the E-MAD CWD. At each sampling location, three samples were collected: (1) surface interval (0 to $15 \mathrm{~cm}$ [0 to 6 in.]); (2) bottom interval (a minimum sampling depth of $168 \mathrm{~cm}$ [66 in.] and a maximum sampling depth of $274 \mathrm{~cm}$ [108 in.] was reported for the samples collected); and (3) tailings which consisted of a composite sample from ground surface to total depth at each location. Gamma spectroscopy was used to analyze the soil samples and only those radionuclides detected were reported by REECo (1986). Table 2-1 summarizes the maximum and minimum activity levels of the isotopes that were detected in the soil samples. Radionuclides of concern include fission and activation products, Cesium-137 $\left({ }^{137} \mathrm{Cs}\right)$ and Cobalt-60 $\left({ }^{60} \mathrm{Co}\right)$. These radionuclides were detected at the surface and higher levels of ${ }^{137} \mathrm{Cs}$ were identified at the lower depths of both CWDs. No nonradioactive hazardous substances were detected at the R-MAD and E-MAD CWDs (REECo, 1986).

In accordance with the DOE/NV National Environmental Policy Act (NEPA) compliance program, a NEPA checklist shall be completed prior to commencement of site investigation activities at this CAU site. This checklist compels DOE/NV to evaluate this proposed project against a list of several potential environmental impacts which include, but are not limited to, air quality, chemical use, waste generation, noise level, and land use. Completion of the checklist results in a determination of the 
appropriate level of NEPA documentation by the DOE/NV NEPA Compliance Officer for this project.

Table 2-1

List of Detected Radionuclides in Soil Samples Collected Prior to 1986

\begin{tabular}{|c|c|c|c|c|}
\hline \multirow{2}{*}{$\begin{array}{l}\text { Isotope } \\
\text { Sampled }\end{array}$} & \multicolumn{2}{|c|}{ R-MAD Facility CWD \#1 Results ${ }^{1}$} & \multicolumn{2}{|c|}{ E-MAD Facility CWD \#2 Results ${ }^{1}$} \\
\hline & $\begin{array}{c}\text { Minimum } \\
\text { Activity }(\mathrm{pCi} / \mathrm{g})\end{array}$ & $\begin{array}{c}\text { Maximum } \\
\text { Activity }(\mathrm{pCi} / \mathrm{g})\end{array}$ & $\begin{array}{c}\text { Minimum } \\
\text { Activity }(\mathrm{pCi} / \mathrm{g})\end{array}$ & $\begin{array}{c}\text { Maximum } \\
\text { Activity }(\mathrm{pCi} / \mathrm{g})\end{array}$ \\
\hline${ }^{40} \mathrm{~K}$ & 25.1 & 30.5 & 29.3 & 32.3 \\
\hline${ }^{60} \mathrm{Co}$ & Not detected & 11.2 & Not Detected & Not Detected \\
\hline${ }^{137} \mathrm{Cs}$ & 1.01 & 403 & 0.114 & 34.7 \\
\hline${ }^{226} \mathrm{Ra}$ & 0.818 & 98.2 & 0.81 & 0.964 \\
\hline${ }^{228} \mathrm{Th}$ & 1.34 & 2.1 & 1.47 & 1.68 \\
\hline${ }^{232} \mathrm{Th}$ & 1.05 & 2.33 & 1.36 & 1.65 \\
\hline
\end{tabular}

${ }^{1}$ Results reported in REECo (1986) as previously unreported data. $\mathrm{pCi} / \mathrm{g}=$ Picocurie $(\mathrm{s})$ per gram 


\subsection{Objectives}

The following section identifies the four primary objectives related to site investigation: conceptual site models, contaminants of potential concern, preliminary action levels, and the DQO process discussion for the CWDs. The sampling objectives were determined through the DQO process between the DOE/NV and the NDEP (Appendix A). This process included an evaluation of the preliminary geophysical assessment (SAIC, 1998 and 1999). The DQOs are qualitative and quantitative statements that specify the quality of the data required to support evaluation of potential corrective actions for the CWDs. The DQOs were developed to clearly define the purpose(s) for which environmental data will be used and to design an investigation plan that will satisfy the site investigation goals.

\subsection{Conceptual Site Model}

The site conceptual model (Table 3-1) provides the basis for planning adequate investigative activities and was developed to postulate potential contaminant exposure pathways from the CWDs. The conceptual model is based on the physical setting of the CWDs (Section 2.1), existing process knowledge, a geophysical investigation performed to identify disposal areas (SAIC, 1998 and 1999), and assumptions and premises that were discussed during the DQO process (Appendix A). If the environmental sampling results indicate that the conceptual model is significantly insufficient, NDEP will be notified, and the site investigation will be rescoped. The following summarizes the primary assumptions which were included in the DQOs and which were considered when formulating the conceptual models for each CWD:

- The landfill disposal areas contain solid wastes contaminated with radioactivity.

- Radionuclides are the primary constituents of concern and are located in disposal areas.

- Vertical and lateral migration of COPCs is not likely.

- If contaminant migration has occurred, it will be limited to the soil beneath the CWD disposal areas.

Through process knowledge and historical photographs, the potential contaminant sources at the CWDs have been identified as solid radioactive wastes buried beneath ground surface. Because the 
Table 3-1

Conceptual Model

\begin{tabular}{|c|c|c|}
\hline $\begin{array}{c}\text { Conceptual } \\
\text { Model Element }\end{array}$ & Assumptions & Source \\
\hline \multirow{4}{*}{ SYSTEM DYNAMICS } & $\begin{array}{l}\text { Radionuclides are the primary concern: Buried wastes } \\
\text { include activation products, mixed fission products, and } \\
\text { potential fuel particles as contaminants. }\end{array}$ & $\begin{array}{l}\text { Knowledge of past operations. } \\
\text { Sample results (REECo, 1986) } \\
\text { Radionuclide calculations } \\
\text { (Tinney and Wheeler, 1999) }\end{array}$ \\
\hline & $\begin{array}{l}\text { Groundwater contamination is unlikely because of } \\
\text { environmental conditions at the site, such as an arid } \\
\text { climate, low permeabilities, and depth to groundwater at } \\
\text { between } 900 \text { and } 950 \mathrm{ft} \text { are not conductive to downward } \\
\text { migration. }\end{array}$ & Knowledge of similar Area 25 Sites \\
\hline & $\begin{array}{l}\text { No driving forces other than limited precipitation and } \\
\text { infiltration. Also, no known free liquids were released to } \\
\text { the radioactive waste dumps. Analytical solutions were } \\
\text { stabilized with adsorbent materials prior to burial. }\end{array}$ & $\begin{array}{c}\text { Knowledge of past operations and similar sites } \\
\text { (IT, 1998) }\end{array}$ \\
\hline & $\begin{array}{l}\text { Hazardous constituents are not known to have been } \\
\text { disposed in the E-MAD and R-MAD dumps. }\end{array}$ & Knowledge of past operations \\
\hline \multirow[b]{2}{*}{ SOURCE LOCATION } & $\begin{array}{l}\text { Location and size of waste areas are estimated from } \\
\text { aerial photographs and geophysics. Location of the } \\
\text { majority of the buried metallic material is based on } \\
\text { geophysical survey data. Location of all waste material } \\
\text { is not known. Surface gamma readings are known. }\end{array}$ & Geophysical and surface radiological surveys \\
\hline & $\begin{array}{l}\text { The waste areas include: } \\
\text { 1) R-MAD trestle pit } \\
\text { 2) R-MAD East pits (2) } \\
\text { 3) R-MAD south mound (TNT) } \\
\text { 4) R-MAD West trenches (6) } \\
\text { 5) R-MAD West pit (south) } \\
\text { 6) E-MAD trench }\end{array}$ & $\begin{array}{c}\text { DOE/NV, 1969c } \\
\text { Wallace, } 1965 \\
\text { Sanders, } 1965 \mathrm{a} \text { and b } \\
\text { DOE/NV, } 1970 \\
\text { IT, 1998 } \\
\text { DOE/NV, 1969a }\end{array}$ \\
\hline \multirow[b]{2}{*}{$\begin{array}{l}\text { LATERAL } \\
\text { MOVEMENT OF } \\
\text { CONTAMINANTS }\end{array}$} & $\begin{array}{l}\text { Subsurface effects limited by relatively low mobility of } \\
\text { constituents. }\end{array}$ & Process Knowledge \\
\hline & $\begin{array}{l}\text { The potential lateral migration of contaminants is } \\
\text { unknown. If migration has occurred, it is most likely } \\
\text { confined to the boundaries of the waste dump disposal } \\
\text { areas. Any lateral movement of surface contamination } \\
\text { may be the result of erosion. }\end{array}$ & $\begin{array}{c}\text { Hale and Westenburg, } 1995 \text { and knowledge of } \\
\text { similar areas }\end{array}$ \\
\hline $\begin{array}{l}\text { VERTICAL } \\
\text { MOVEMENT OF } \\
\text { CONTAMINANTS }\end{array}$ & $\begin{array}{l}\text { The vertical movement of contaminants is unknown. } \\
\text { Vertical migration is expected to be limited by the lack of } \\
\text { a driving force and relatively low mobility of } \\
\text { contaminates. There is no indication that vertical } \\
\text { movement will extend beyond trench bottoms. }\end{array}$ & Knowledge of similar Area 25 Sites \\
\hline $\begin{array}{l}\text { PHYSICAL AND } \\
\text { PRACTICAL } \\
\text { CONSTRAINTS }\end{array}$ & $\begin{array}{l}\text { Nearby railroad tracks and fencing; adverse weather } \\
\text { conditions; heavy equipment and resource availability; } \\
\text { and approvals are possible constraints. }\end{array}$ & Site and practical knowledge \\
\hline FUTURE USE & $\begin{array}{l}\text { Area } 25 \text { is defined as a research and testing area. The } \\
\text { area will be restricted and monitored. }\end{array}$ & Assumptions are defined in DOE/NV 1996c \\
\hline \multirow{2}{*}{$\begin{array}{l}\text { POTENTIAL } \\
\text { EXPOSURES }\end{array}$} & $\begin{array}{l}\text { Very low exposure potential related to unlikely } \\
\text { groundwater contamination. Groundwater is estimated } \\
\text { to be at least } 900 \text { feet below the subject areas. These } \\
\text { depths are greater than } 20 \text { times the expected } \\
\text { maximum contamination depths. }\end{array}$ & Process Knowledge \\
\hline & $\begin{array}{l}\text { Oral ingestion, inhalation, or dermal contact (absorption) } \\
\text { of COPC of the soil is extremely low as the CPT will } \\
\text { provide soil punching. Respiratory protection will be } \\
\text { used as required during drilling or excavation. }\end{array}$ & Process Knowledge \\
\hline
\end{tabular}


disposal areas are covered with soil and are not closed with an engineered cap, a release mechanism may exist via surface water infiltration through waste materials (Section 2.3). The presence of this release mechanism is not considered significant because the CWDs are located in the Mojave Desert where precipitation is minimal (Section 2.1); however, due to the surface water drainage patterns, periodic infiltration of surface water could occur at CWD \#1. Dry washes in the vicinity of CWD \#1 are presented in Figure 3-1. Significant surface water drainage patterns were not observed within the immediate vicinity of CWD \#2 boundaries.

Based on the conceptual model, solid radioactive waste disposal is assumed to impact only shallow site soils. Because the depth to groundwater is approximately $290 \mathrm{~m}(950 \mathrm{ft})$ and because annual precipitation is approximately $13 \mathrm{~cm}(5 \mathrm{in}$.) (DOE/NV, 1988c), the site is not considered to have impacted groundwater. Site access into the CWDs is restricted by fences posted with appropriate signage, mitigating the potential for inadvertent exposure to subsurface site soils.

\subsection{Potential Contaminants of Concern}

The following COPCs were developed between the DOE/NV and the NDEP:

- Radionuclides

- Volatile organic compounds (VOCs)

- Semivolatile organic compounds (SVOCs)

- RCRA metals

Previous sampling identified ${ }^{137} \mathrm{Cs}$ and ${ }^{60} \mathrm{Co}$ in pits and trenches in R-MAD and E-MAD. Activation products suspected as present in the CAU include ${ }^{60} \mathrm{Co}$, europium-152 $\left({ }^{152} \mathrm{Eu}\right)$, and niobium-94 $\left({ }^{94} \mathrm{Nb}\right)$. Mixed fission products and potential fuel particles that may be found in the unit include ${ }^{137} \mathrm{Cs}$, strontium-90 $\left({ }^{90} \mathrm{Sr}\right)$, plutonium-239 $\left({ }^{239} \mathrm{Pu}\right)$, uranium-234 $\left({ }^{234} \mathrm{U}\right)$ and uranium-235 $\left({ }^{235} \mathrm{U}\right)$.

While there is no information indicating disposal of hazardous or Resource Conservation and Recovery Act (RCRA)-regulated materials in the CWDs, analyses will be run for VOCs, SVOCs, and RCRA metals to verify the conceptual model. 


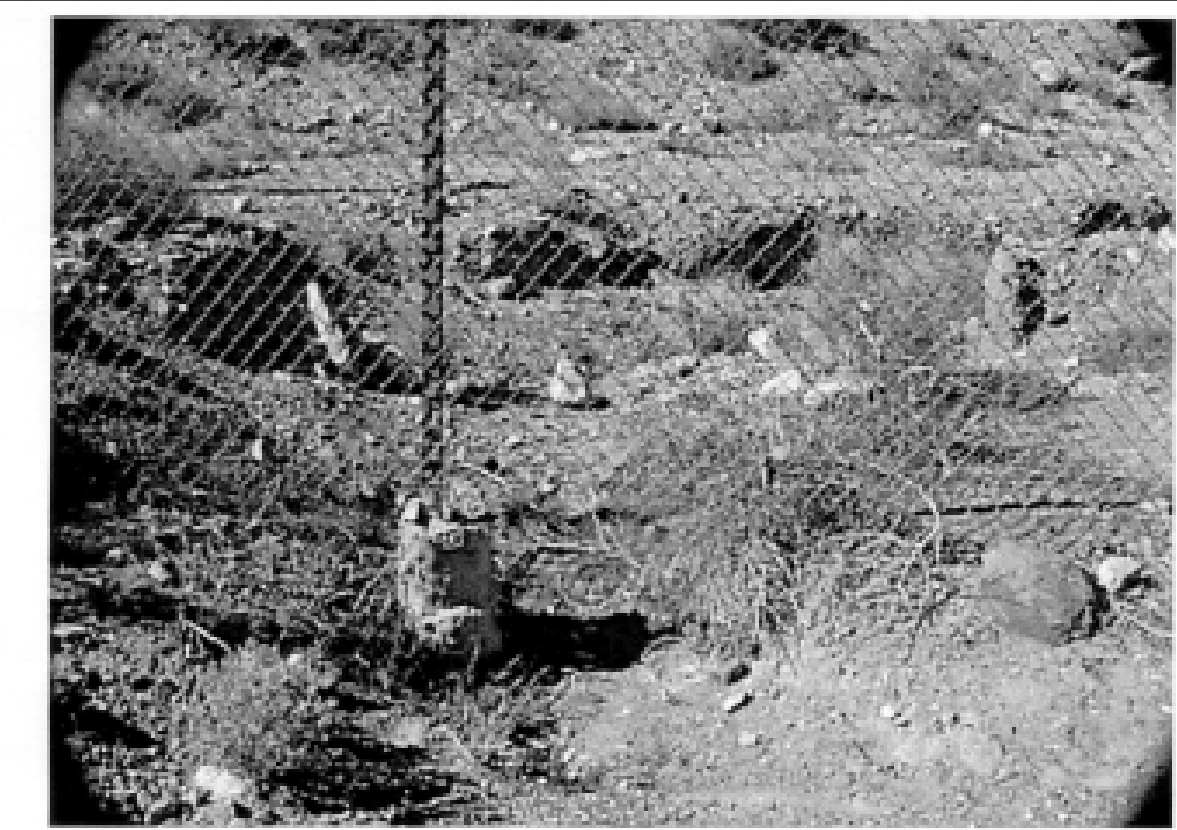

Figure 3-1a: Dry wash draining out of CWD \#1. (Location A in Figure 3-1f)

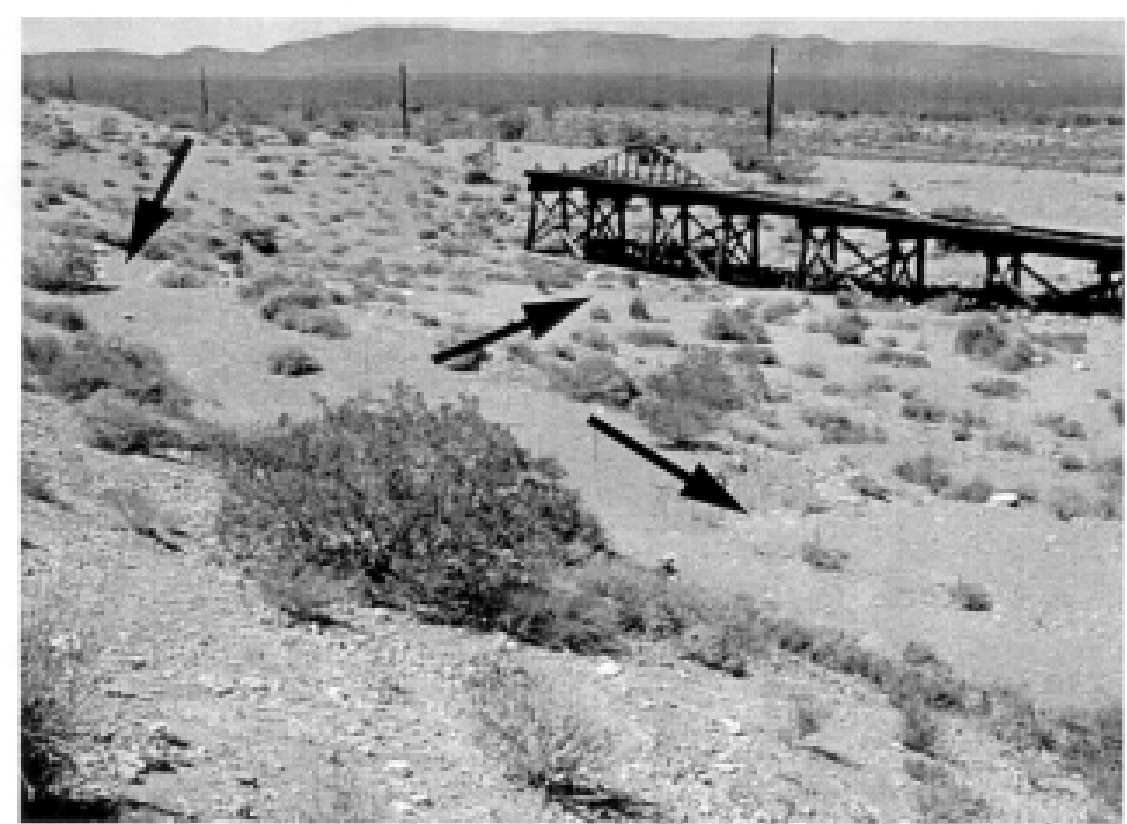

Figure 3-1d: Dry washes draining into the burial pit below the CWD \# trestle. (Location D in Figure 3-1f

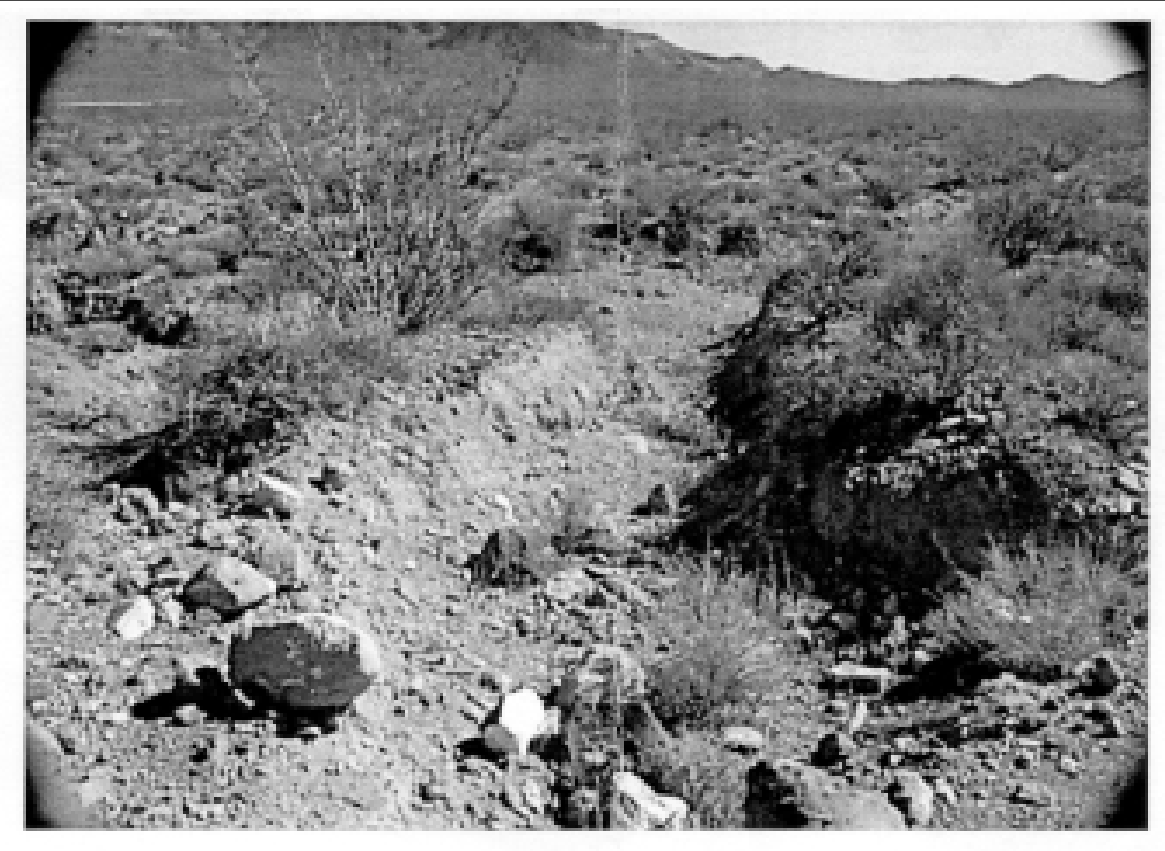

Figure 3-1b; Continuation of the dry wash identified in Figure 3-1a. (Location B in Figure 3-1f)

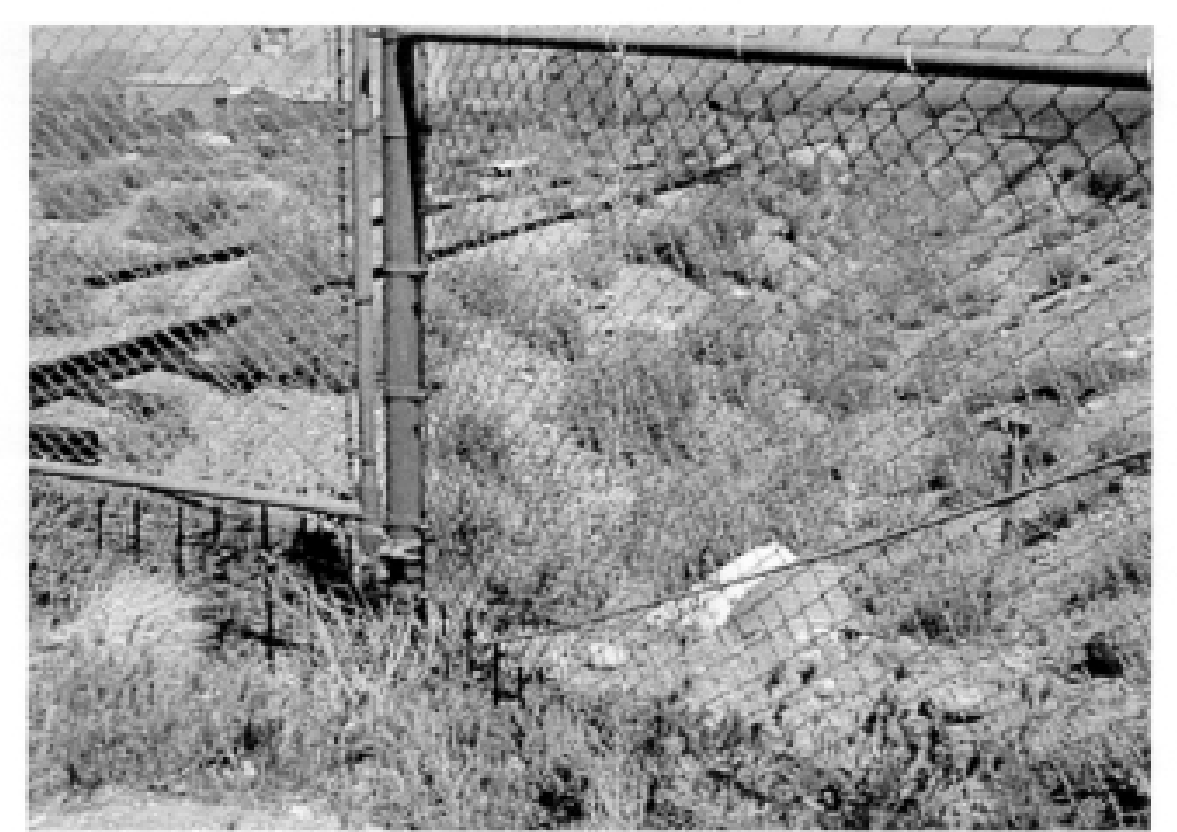

Figure 3-1e: Dry wash draining into CWD \#1 parallel to the trestle spur. The unobservable end of the drainage pipe is buried and dead ents into site soils approximately $1 \mathrm{~m}(3 \mathrm{ft})$ inside the fenceline. Surface water drainage is believed to have eroded site soil to ground surface at the end of the buried portion of the drainage pipe. (Location E in Figure 3-1f)

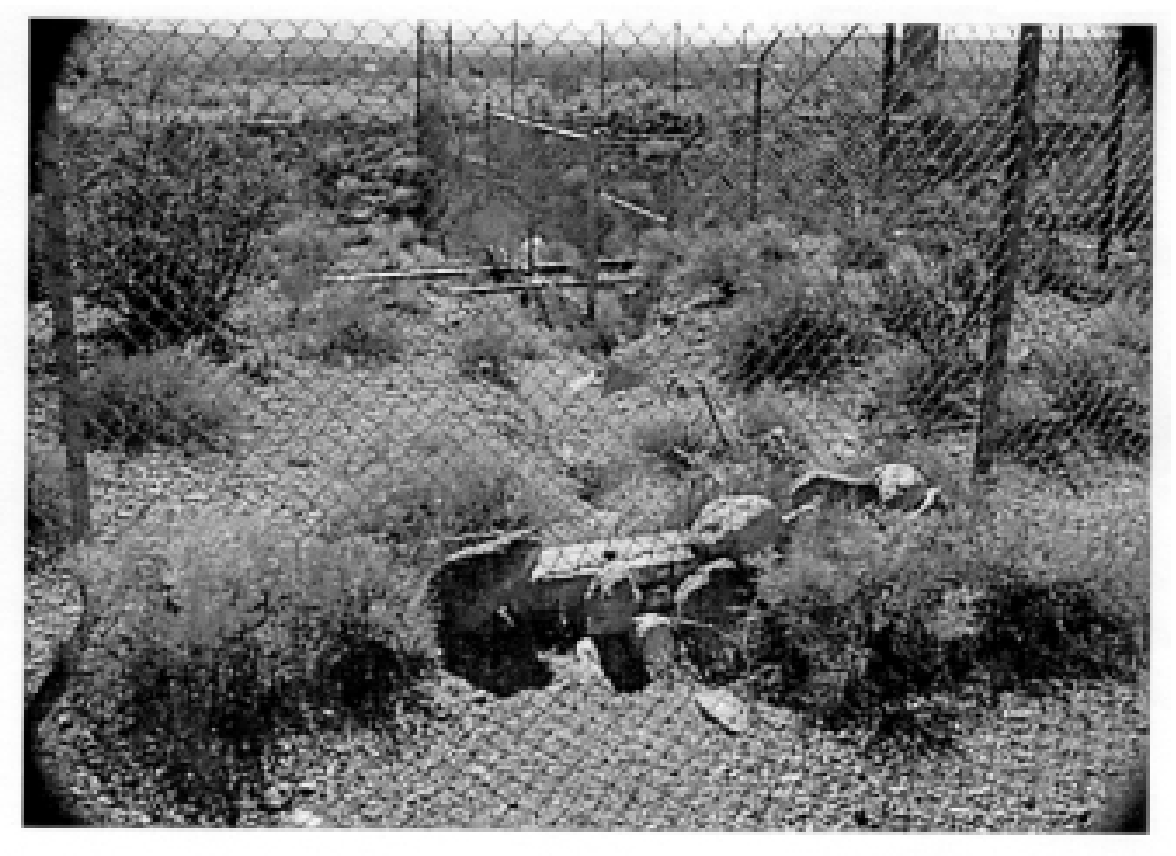

Figure 3-1c: Dry wash draining from the east into CWD \#1. (Location C in Figure 3-1f)

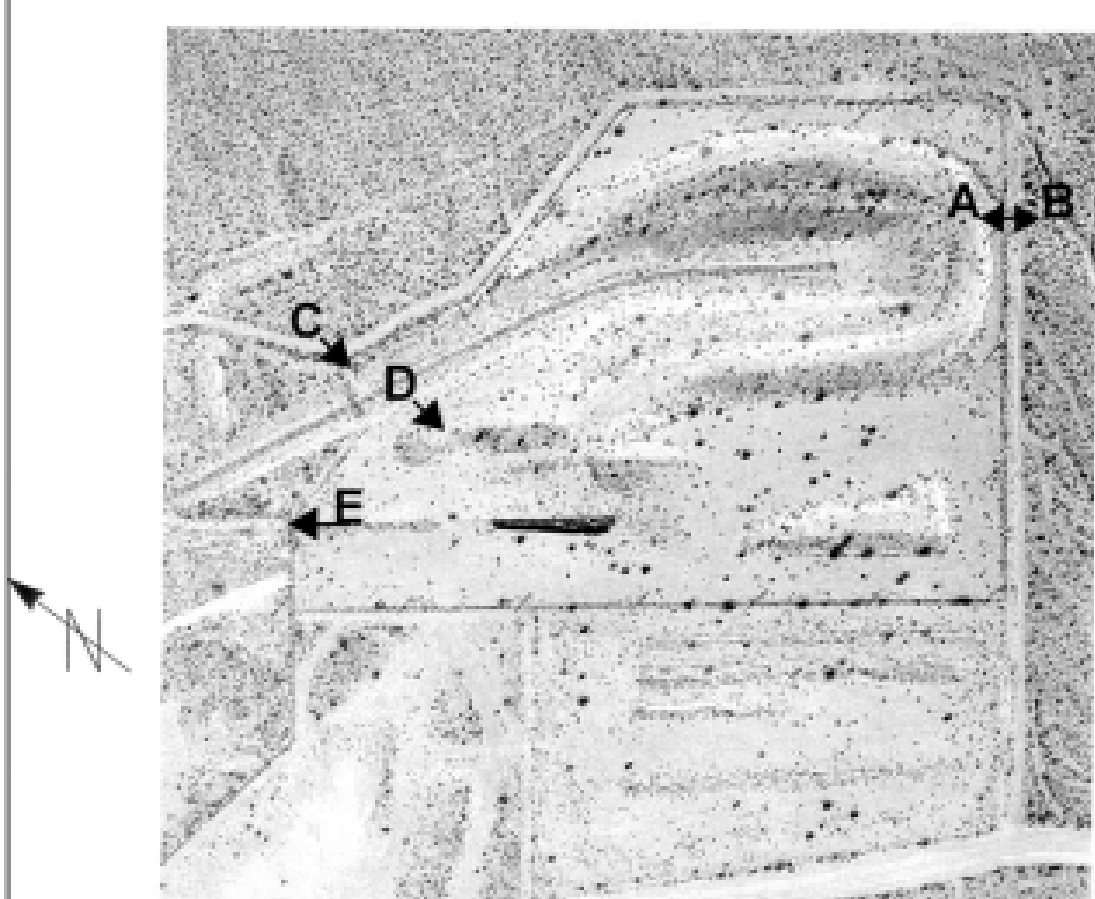

Source: EGSG Photograph Numbecss1-69,EGSG, 1968) W

Figure 3-1f: Aerial photograph of CWD \#1. Arrows indicate the direction at which Figure 3-1 photographs were acquired. 


\subsection{Preliminary Action Levels}

Preliminary action levels (PALs) for on-site screening, on-site analysis, and off-site laboratory analysis are provided in Table A.3-1 and will be used to determine the presence of contamination.

\subsubsection{Field Screening Levels}

The following field screening levels will be used to compare on-site field screening levels:

- The radiological (alpha and beta/gamma) screening levels are defined as the mean in situ background levels plus two times the standard deviation using in situ gamma spectrometry.

- The VOC soil gas screening levels are defined as 20 parts per million (ppm) or 2.5 times background, whichever is greater, using in situ photoionization detector (PID) and flame ionization detector (FID).

Radiation background and VOC background will be determined from in situ soil measurements made at depth with the CPT instruments outside the CWDs. The data from these pushes will be integrated over the length of the push and these data will be used as background. Daily background checks will be made with check sources to determine whether the instrument's response meets project requirements, prior to use in the field.

Concentrations exceeding field screening levels indicate potential contamination at the sample location. This information will be documented, and the investigation will be continued to obtain field analytical results for radionuclide identification and VOC speciation.

\subsubsection{Field Analyses}

Field analyses will be used to identify gamma-emitting radionuclides using in situ gamma spectroscopy analysis. Field analyses using a gas chromatograph/mass spectrometer (GC/MS) will provide data on VOC speciation and concentrations in soil gas. This field analytical data will provide information to assist in determining "step-out" sampling locations to define lateral extent of contamination. The field screening data and the results from field analyses will provide information for selecting locations for biased soil samples to be submitted for laboratory analysis. 


\subsubsection{Chemical Preliminary Action Levels}

Field and off-site laboratory analytical chemistry results will be compared to the the following PALs to evaluate the need for possible corrective actions:

- The NDEP Corrective Action Regulations listed in the Nevada Administrative Code (NAC), NAC 445A.226 - NAC 445A.22755 (NAC, 1998a)

- Total petroleum hydrocarbons (TPH) above the TPH limit of 100 ppm per the NAC 445A.2272 (NAC, 1998b) and NAC 459.9973 (NAC, 1998c)

\subsubsection{Radiological Preliminary Action Levels}

The preliminary action levels for the radionuclides are isotope-specific and are defined as the maximum concentration for that isotope found in environmental samples taken from undisturbed background locations. Environmental background samples will be taken in the vicinity of CAU 143. These samples will be analyzed and compared with the results for environmental samples taken from other undisturbed background locations in Area 25. In addition, the radionuclide concentrations in the CAU 143 and Area 25 background samples will be compared with the radionuclide concentrations found in environmental samples taken from undisturbed background locations in the vicinity of the NTS presented in McArthur and Miller (1989) and Atlan-Tech (1992). The PAL for each isotope will be the maximum concentration of that isotope found in any samples taken from the undisturbed background locations described above.

Field analytical and laboratory results above action levels indicate the presence of COPCs at levels which may require corrective action. The evaluation of potential corrective actions and the justification for a preferred action will be evaluated in the Corrective Action Decision Document (CADD) which will be based on the results of this field investigation.

\subsection{DQO Process Discussion}

Details of the DQO process are presented in Appendix A. The DQO results for this CAU indicated the need for a biased sampling approach. Due to potential subsurface migration of COPC, an investigation consisting primarily of subsurface sampling was identified. The COPCs, analytical methods, and reporting limits prescribed through the DQO process are provided in Table 4-1. The 
laboratory precision and accuracy requirements are those stated in the latest revision of the individual EPA SW-846 analytical methods (EPA, 1996). Representativeness of the investigation and resulting data will be evaluated by confirming or refuting the conceptual model. 


\subsection{Field Investigation}

This section of the CAIP contains the sampling approach for investigating the CWDs. All sampling activities will be conducted in compliance with the Industrial Sites QAPP (DOE/NV, 1996b) and other applicable, approved procedures. Quality assurance/quality control requirements for field and laboratory environmental sampling are contained in the Industrial Sites QAPP (DOE/NV, 1996b) and in Table 4-1.

Table 4-1

Laboratory Analytical Requirements

(Page 1 of 2)

\begin{tabular}{|c|c|c|c|c|c|}
\hline Analyte & Medium $^{a}$ & $\begin{array}{l}\text { Analytical } \\
\text { Method }\end{array}$ & $\begin{array}{c}\text { Minimum } \\
\text { Reporting Limit }^{\mathrm{b}}\end{array}$ & $\begin{array}{l}\text { Precision } \\
\text { (RPD) }\end{array}$ & $\begin{array}{c}\text { Accuracy } \\
(\% \mathrm{R})\end{array}$ \\
\hline \multirow{2}{*}{$\begin{array}{c}\text { Total VOCs } \\
\text { (in subsurface soils) }\end{array}$} & Water & \multirow{2}{*}{$8260 B^{c}$} & \multirow{2}{*}{$\begin{array}{c}\text { Analyte-specific } \\
\text { estimated quantitation } \\
\text { limits }^{d}\end{array}$} & 14 & $61-145$ \\
\hline & Soil & & & 24 & $59-172$ \\
\hline \multirow{2}{*}{$\begin{array}{c}\text { TotalSVOCs } \\
\text { (in subsurface soils) }\end{array}$} & Water & \multirow{2}{*}{$8270 C^{c}$} & \multirow{2}{*}{$\begin{array}{c}\text { Analyte-specific } \\
\text { estimated quantitation } \\
\text { limits }^{d}\end{array}$} & 50 & $9-127$ \\
\hline & Soil & & & 50 & $11-142$ \\
\hline $\begin{array}{c}\text { Total RCRA Metals } \\
\text { Arsenic } \\
\text { Barium } \\
\text { Cadmium } \\
\text { Chromium } \\
\text { Lead } \\
\text { Mercury } \\
\text { Selenium } \\
\text { Silver }\end{array}$ & Water & $6010 \mathrm{~B} / 7470 \mathrm{~A}^{\mathrm{c}}$ & $\begin{array}{c}10 \mu \mathrm{g} / \mathrm{L} \\
200 \mu \mathrm{g} / \mathrm{L} \\
5 \mu \mathrm{g} / \mathrm{L} \\
10 \mu \mathrm{g} / \mathrm{L} \\
3 \mu \mathrm{g} / \mathrm{L} \\
0.2 \mu \mathrm{g} / \mathrm{L} \\
5 \mu \mathrm{g} / \mathrm{L} \\
10 \mu \mathrm{g} / \mathrm{L}\end{array}$ & 20 & $75-125$ \\
\hline $\begin{array}{c}\text { Total RCRA Metals } \\
\text { Arsenic } \\
\text { Barium } \\
\text { Cadmium } \\
\text { Chromium } \\
\text { Lead } \\
\text { Mercury } \\
\text { Selenium } \\
\text { Silver }\end{array}$ & Soil & $6010 \mathrm{~B} / 7471 \mathrm{~A}^{\mathrm{c}}$ & $\begin{array}{c}1 \mathrm{mg} / \mathrm{kg} \\
20 \mathrm{mg} / \mathrm{kg} \\
0.5 \mathrm{mg} / \mathrm{kg} \\
1 \mathrm{mg} / \mathrm{kg} \\
0.3 \mathrm{mg} / \mathrm{kg} \\
0.1 \mathrm{mg} / \mathrm{kg} \\
0.5 \mathrm{mg} / \mathrm{kg} \\
1 \mathrm{mg} / \mathrm{kg}\end{array}$ & 20 & $75-125$ \\
\hline \multirow{4}{*}{$\begin{array}{l}\text { Total Petroleum } \\
\text { Hydrocarbons }\end{array}$} & Water (gasoline) & \multirow{4}{*}{ 8015B modified ${ }^{c}$} & $0.1 \mathrm{mg} / \mathrm{L}$ & 20 & $25-145$ \\
\hline & Water (diesel) & & $0.5 \mathrm{mg} / \mathrm{L}$ & 20 & $25-145$ \\
\hline & Soil (gasoline) & & $0.5 \mathrm{mg} / \mathrm{kg}$ & 30 & $30-130$ \\
\hline & Soil (diesel) & & $25 \mathrm{mg} / \mathrm{kg}$ & 30 & $30-130$ \\
\hline
\end{tabular}


Table 4-1

\section{Laboratory Analytical Requirements}

(Page 2 of 2)

\begin{tabular}{|c|c|c|c|c|c|}
\hline Analyte & Medium $^{a}$ & $\begin{array}{l}\text { Analytical } \\
\text { Method }\end{array}$ & $\begin{array}{c}\text { Minimum } \\
\text { Reporting Limit }^{\mathrm{b}}\end{array}$ & $\begin{array}{l}\text { Precision } \\
\text { (RPD) }\end{array}$ & $\begin{array}{c}\text { Accuracy } \\
(\% \mathrm{R})\end{array}$ \\
\hline \multirow{2}{*}{$\begin{array}{c}\text { Gamma } \\
\text { Spectroscopy } \\
\text { (based on } \mathrm{Cs}^{137} \text { ) }\end{array}$} & Water & EPA $901.1^{\mathrm{e}}$ & $20 \mathrm{pCi} / \mathrm{L}$ & 20 & $80-120$ \\
\hline & Soil & $\begin{array}{c}\text { HASL } 300 \\
4.5 .2 .3^{\dagger}\end{array}$ & $0.2 \mathrm{pCi} / \mathrm{g}$ & 35 & $80-120$ \\
\hline \multirow{2}{*}{ Isotopic Plutonium } & Water & NAS-NS-3058 & $2.0 \mathrm{pCi} / \mathrm{L}$ & 20 & $80-120$ \\
\hline & Soil & NAS-NS-3058 & $0.4 \mathrm{pCi} / \mathrm{g}$ & 35 & $80-120$ \\
\hline \multirow{2}{*}{ Isotopic Uranium } & Water & NAS-NS-3050 & $2 \mathrm{pCi} / \mathrm{L}$ & 20 & $80-120$ \\
\hline & Soil & NAS-NS-3050 & $1.0 \mathrm{pCi} / \mathrm{g}$ & 35 & $80-120$ \\
\hline \multirow{2}{*}{ Gross Alpha } & Water & EPA $900^{\circ}$ & $1.0 \mathrm{pCi} / \mathrm{L}$ & $<20$ & $80-120$ \\
\hline & Soil & SM-7110 & $10 \mathrm{pCi} / \mathrm{g}$ & $<35$ & $80-120$ \\
\hline \multirow{2}{*}{ Gross Beta } & Water & EPA $900^{\circ}$ & $4 \mathrm{pCi} / \mathrm{L}$ & $<20$ & $80-120$ \\
\hline & Soil & SM-7110i & $10 \mathrm{pCi} / \mathrm{g}$ & $<35$ & $80-120$ \\
\hline
\end{tabular}

${ }^{\mathrm{a}} \mathrm{QC}$ (water) samples are included in table

${ }^{\mathrm{b}}$ Industrial Sites Quality Assurance Project Plan (DOE/NV, 1996b)

'EPA Test Methods for Evaluating Solid Waste, 3rd Edition, Parts 1-4, SW-846 (EPA, 1996)

${ }^{d}$ Estimated Quantitation Limit (EQL) as given in Method SW-846, U.S. EPA (EPA, 1996)

${ }^{\text {e }}$ Prescribed Procedures for Measurement of Radioactivity in Drinking Water (Kreiger and Whittaker, 1980)

${ }^{\dagger}$ Environmental Measurements Laboratory Procedures Manual, HASL-300, U.S. Department of Energy (DOE, 1992)

'National Academy of Sciences (NAS), Nuclear Science Series, September 1963 (NAS, 1962)

${ }^{\mathrm{h}}$ The Radiochemistry of Uranium, J.E. Grindler, in Nuclear Science Series, NAS-NS-3050. (NAS, 1962).

iStandard Methods for the Examination of Water and Wastewater, American Public Health Association, 1998

RPD $=$ Relative percent difference $=100$ (Sample Result-Duplicate Result) $/($ Sample Result+Duplicate Result $/ 2)$

$\% \mathrm{R}=$ Percent recovery

$\mathrm{mg} / \mathrm{kg}=$ Milligram(s) per kilogram

$\mathrm{pCi} / \mathrm{g}=$ Picocurie(s) per gram

$\mathrm{pCi} / \mathrm{L}=$ Picocurie(s) per liter

$\mathrm{mg} / \mathrm{L}=\operatorname{Milligram}(\mathrm{s})$ per liter

$\mu \mathrm{g} / \mathrm{L}=$ Microgram(s) per liter

\subsection{Technical Approach}

The site investigation includes the following activities:

- Geophysics has been performed to determine the location and extent of the waste disposal areas

- Performing CPT within and/or near radioactive solid waste disposal sites

- Conducting field analyses for radiological constituents and VOCs with the instruments in the CPT

- Collecting confirmatory surface and subsurface environmental soil samples using CPT and/or sonic drilling 
- Collecting geotechnical subsurface soil samples

- Collecting background and subsurface soil samples

- Collecting required quality control samples

- Surveying sampling locations and the CWDs

\subsubsection{Geophysical Investigation}

Biased locations will be selected for CPT pushes. The biased approach is appropriate because the locations of the waste disposal areas are relatively well known or can be reasonably assumed. Lithological data, soil gas information, and total gamma activity surveys will be conducted continuously.

Geophysical surveys conducted under a preliminary investigation of CAU 143 were used to guide and optimize surface and subsurface sampling locations (SAIC, 1998 and 1999). The geophysical investigation confirmed the assumed location of the waste disposal areas within each CWD and identified additional burial locations within and outside of R-MAD CWD\#1. An electromagnetic conductivity meter (EM-31) was used to initially determine the most likely locations of the waste disposal sites containing buried metal. An EM-61 high-resolution metal detector was then utilized to confirm the presence of metallic waste and to gain a sense for depth at which identified buried waste is located. Potential disposal sites observed with the EM-31 and not with the EM-61 are considered to be near surface debris or wastes at depths of greater than $5 \mathrm{~m}(16 \mathrm{ft})$ bgs. Potential disposal sites identified with the EM-31 and EM-61 are considered to be near surface debris or wastes at depths up to $5 \mathrm{~m}$ (16 ft) bgs. In select areas where suspected disposal sites were observed through use of the EM-31 and/or EM-61, magnetometer and ground penetrating radar (GPR) surveys were additionally performed to further characterize suspected waste disposal areas.

Following the preliminary survey of CWDs, electromagnetic imaging was performed in the R-MAD dumps and at the location of a suggested pit south of R-MAD-West. These studies used a computer-driven dipole-dipole array to image the resistivity of a section through the identified dump sites. These images have proven useful in determining the depth of disturbed areas previously identified as burial areas. The information from these lines has been mapped in three dimensions, providing a basis for selecting target locations within the R-MAD CWD for CPT investigation. 


\subsubsection{R-MAD Geophysical Results Summary}

In order to accommodate existing site fencing, the R-MAD geophysical survey was managed as two distinct areas: R-MAD-East and R-MAD-West (Figure 4-1). As anticipated, R-MAD-West was found to consist of six buried trenches of a configuration approximate to that of Figure 4-2. Furthermore, the upper $2 \mathrm{~m}$ ( $6 \mathrm{ft}$ ) of soil at R-MAD-West appears to have been excavated or reworked in the past.

At R-MAD-East, buried waste was identified in the vicinity of the burial pit beneath the railroad trestle spur (Figure 4-2, Anomaly A). The vertical extent of the waste could not be accurately determined with the geophysical methods utilized, but the waste was determined to be from $1 \mathrm{~m}(3 \mathrm{ft})$ to over $5 \mathrm{~m}$ (16 ft) bgs. No buried waste was identified at the eastern railroad spur, except in a localized area where waste may be present at a depth of at least $5 \mathrm{~m}(16 \mathrm{ft}$ ) bgs (Figure 4-2, Anomaly G). Buried waste was additionally identified in at least four other localized areas (Figure 4-2, Anomalies C, D, E, and H). Anomalies C and D appear to be greater than $5 \mathrm{~m}$ (16 ft) bgs, and Anomaly E appears to be between $4 \mathrm{~m}(13 \mathrm{ft})$ to over $5 \mathrm{~m}(16 \mathrm{ft}) \mathrm{bgs}$. Anomaly $\mathrm{H}$ appears to be either surface debris or waste at least $5 \mathrm{~m}(16 \mathrm{ft})$ bgs. No waste has been identified in the berm south of the trestle spur (Figure 4-2, Anomaly B). Areas of potential concern on the soil berm surrounding the eastern railroad spur (Figure 4-2, Anomalies F and I) will be verified with geophysics in the field as buried debris or aberrant geophysical data due to surface topography. An additional survey conducted south of R-MAD-West trenches identified the location of a pit.

\subsubsection{E-MAD Geophysical Results Summary}

The geophysical survey data from E-MAD indicated that waste disposal only occurred within the waste trench and between the southern edge of the trench and the northern rim of the soil pile south of the trench (Figure 4-3, Anomaly A). Fill material within the trench is not highly conductive, as indicated by the electromagnetic surveys. Furthermore, the E-MAD waste trench does not appear to be symmetrical at the eastern sidewall of the southern end of the trench. The northern end of the trench appears to be about $3.5 \mathrm{~m}(11 \mathrm{ft})$ wide, and the southern end of the trench appears to be about

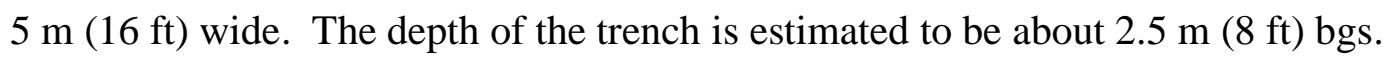




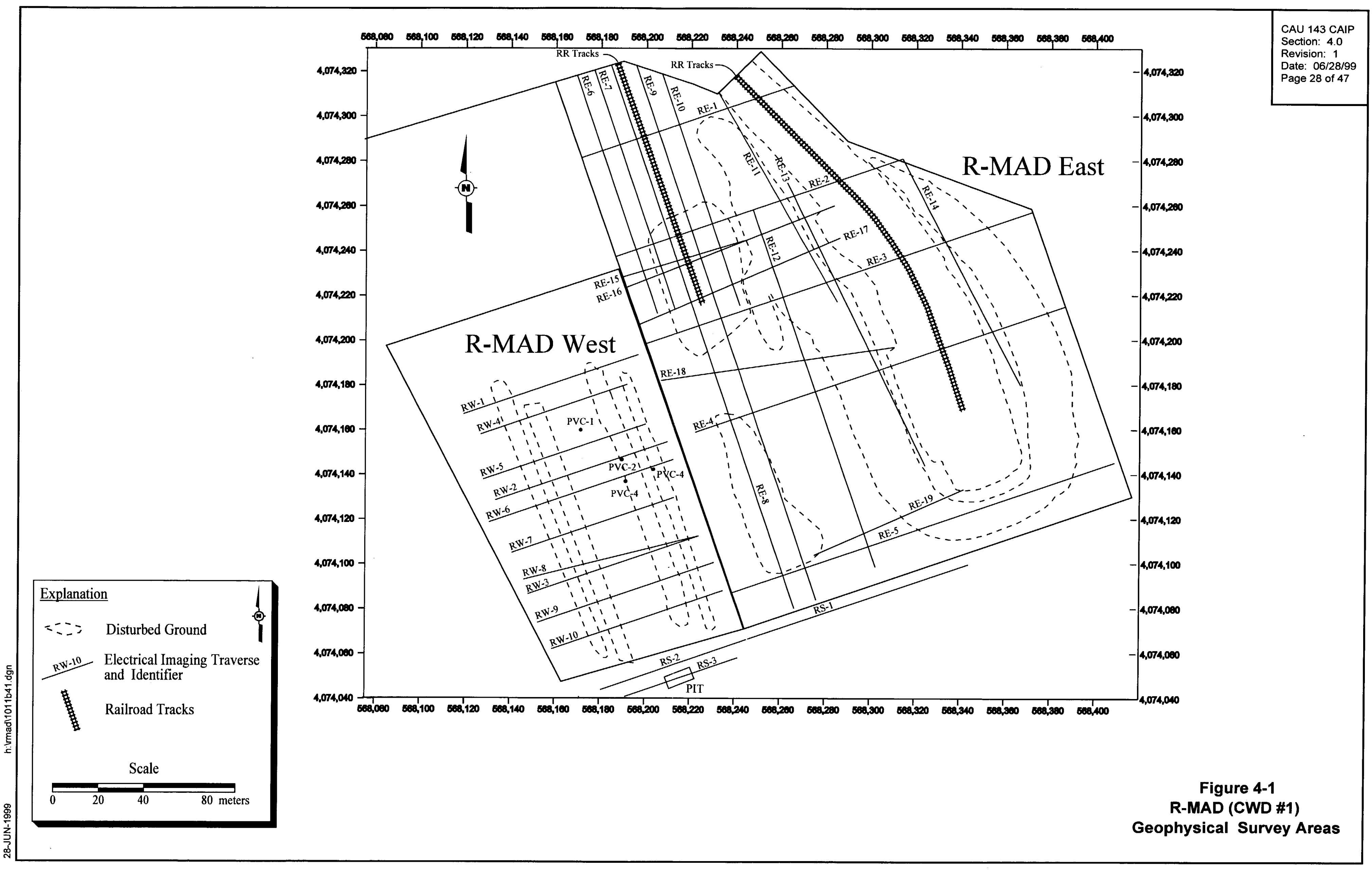




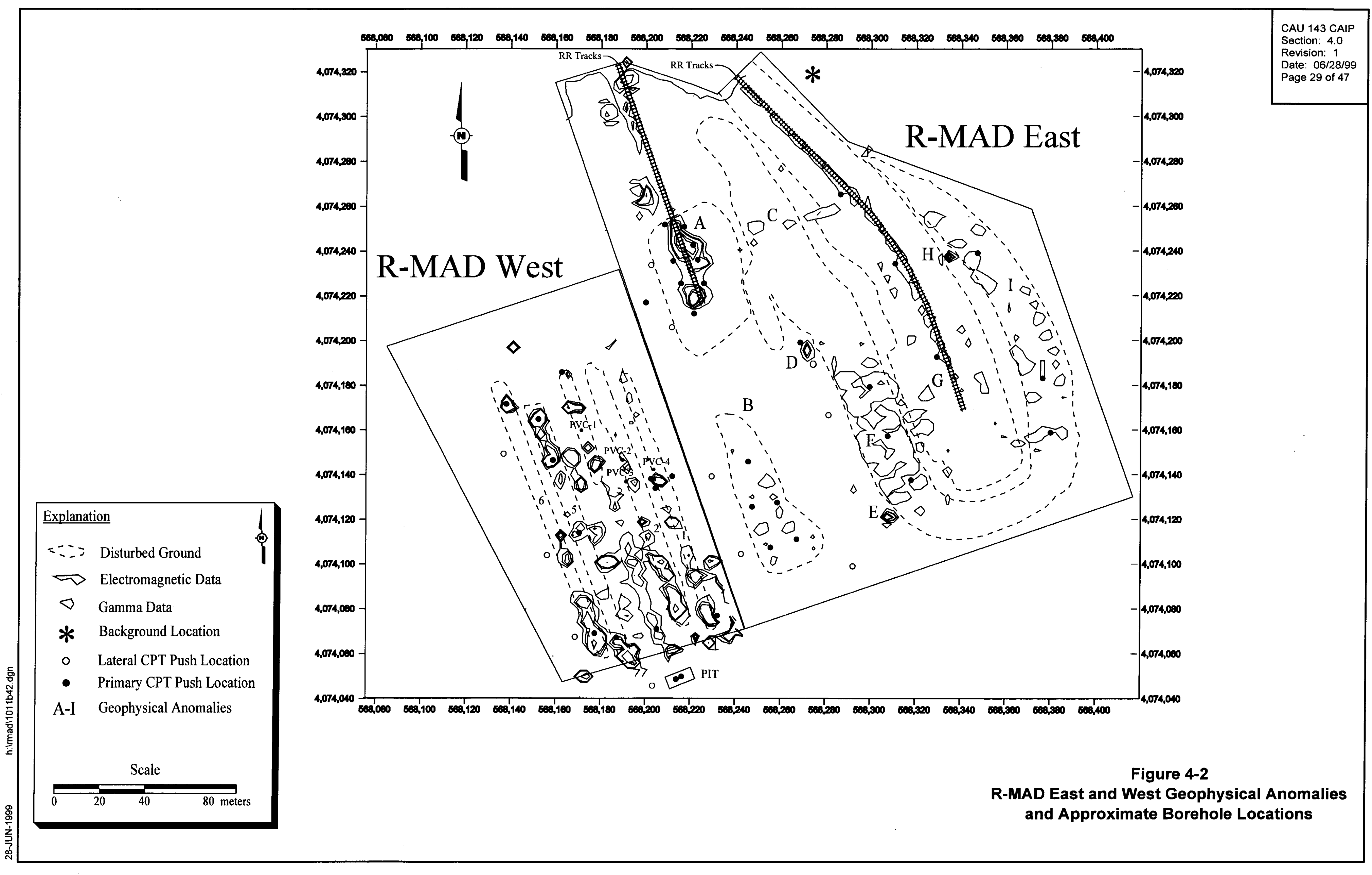




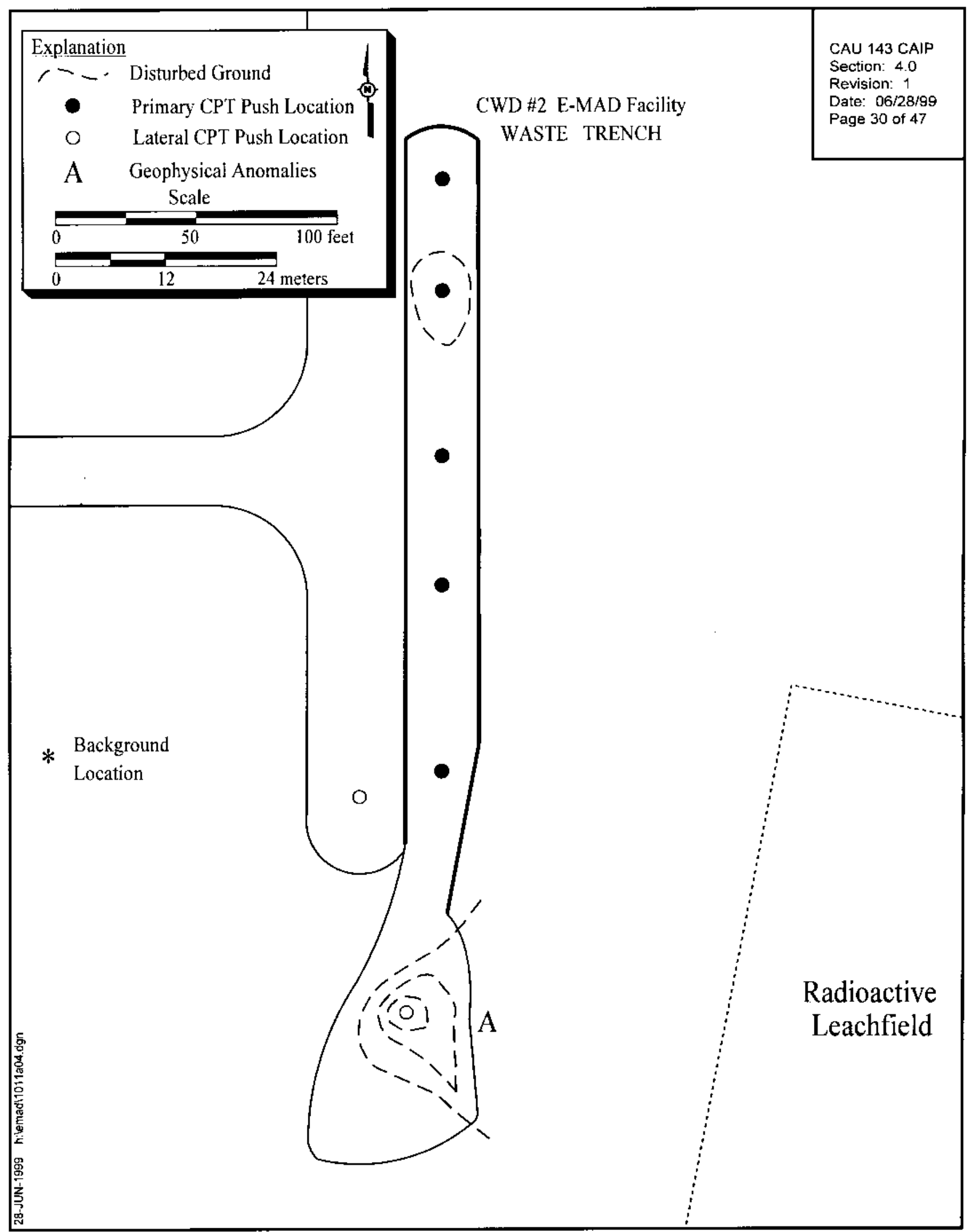

Figure 4-3

E-MAD Geophysical Anomaly and Approximate

Borehole Locations 


\subsubsection{Cone Penetrometer Testing}

A CPT will be used to perform in situ measurements of gamma radiation, radionuclide identification, and VOCs at approximately 40 locations and to collect soil samples from biased locations based on at least 20 percent of the number of in situ sample locations in CAU 143. Preliminary locations are shown in Figures 4-2 and 4-3. The CPT equipped with a sodium iodide scintillation counter will be used to measure radiation and identify radionuclides using gamma-ray spectrometry. The CPT will also be used to perform continuous logging of soil gas using: (1) an onboard Photoionization Detector (PID); (2) a Flame Ionization Detector (FID); and (3) a Gas Chromatograph/Mass Spectrometer (GC/MS) system for VOC analysis. These in situ field measurements and the results of laboratory analyses from soil samples will assist in determining the closure approach for CAU 143. The collective results of the geotechnical information, gamma survey data, and VOC soil gas analyses will be compared to screening levels. Soil sample analytical results will be compared to in situ field data and the PALs (Table A.3-1).

The CPT will be used to define subsurface conditions, gather field analytical data, and subsequently substantiate or refute the conceptual model established during the DQO process. The CPTs will be advanced within or adjacent to areas where wastes are believed to have been disposed. Proposed initial primary and lateral CPT push locations are identified in Figures 4-2 and 4-3. The exact locations will be determined upon initiation of field activities. Generally, CPT pushes will be

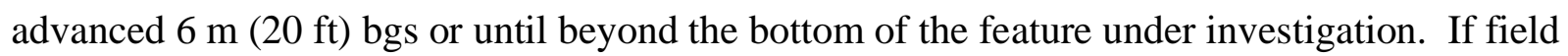
analytical results are negative for radiation and VOCs (Section 3.3) and the bottom of the feature under investigation is identified, the borehole will be terminated 10 feet into the virgin soil, regardless of the depth.

At R-MAD-East (Figure 4-2), geophysical anomalies are associated with areas of historical activity between the rail lines and are identified as deep wastes buried at depths in excess of $5 \mathrm{~m}$ (16 ft) (SAIC, 1998). The CPT sampling will bracket these areas of potential radioactive waste burial. In the trestle area, CPT pushes will be placed in the area where dumping from the rail cars occurred. This pit is considerably deeper than the other burial sites and shows geophysical evidence of abundant metallic debris. Historical information suggests that this pit was at least $12 \mathrm{~m}$ (40 ft) deep and the target depth is set at $15 \mathrm{~m}(50 \mathrm{ft})$. The intent is to reach the area below the bottom of the fill material. The mound in the southwest corner of R-MAD-East has been identified from historical 
information as the burial site of debris from the Transient Nuclear Test (TNT). Geophysical data shows some high conductivity anomalies beneath this mound so a minimum of five pushes will be made from the top of the mound to delimit the waste buried beneath it.

At R-MAD-West (Figure 4-2), CPT pushes will be advanced up to $3 \mathrm{~m} \mathrm{(10} \mathrm{ft)} \mathrm{below} \mathrm{trench} \mathrm{bottoms,}$ as determined by geotechnical data from the CPT. Approximately $30 \mathrm{CPT}$ pushes are planned to delineate the waste locations and the vertical extent of migration. The step-out strategy will be to investigate areas adjacent to elevated levels of radioactivity and any VOC contamination identified by field analytical methods using a 5-ft step-out pattern from the original CPT location.

At E-MAD CWD \#2 (Figure 4-2), five CPT pushes will be advanced along the centerline of the waste trench. The step-out strategy for checking the horizontal extent of contamination is the same as that used for the R-MAD West trenches (Figure 4-3).

The characterization method should identify potential vertical contamination at the site, but additional step-out pushes may be used to further delineate the lateral extent of detected COPCs. Any step-out pushes will be made at the discretion of the Site Supervisor.

\subsubsection{In Situ Sampling and Field Analyses}

The CPT will be used to log gamma activity and to screen and measure VOC soil gas. Field analyses for radiation and VOCs will be conducted for all pushes and will provide information to establish the required maximum depth for each push and the need for any step-out pushes. The field analytical methods will consist of radiological analyses utilizing a scintillation detector in the cone of the CPT. Gamma radiation levels will be logged and the cone will be stopped at that level during retraction and the output of the scintillation counter will be directed to a multichannel analyzer for an extended count time to determine the isotopes present. Field analysis for VOCs will be performed utilizing a screened intake behind the cone head which transmits soil vapor samples to the surface. At the surface, VOCs will be detected by a combination of photoionization and flame ionization detectors and, if VOCs are detected, the vapor stream will be routed to a GC/MS for speciation and quantification of the gas phase(s) present. This analytical stream will be performed continuously during the penetration. 
Field analytical data will serve three purposes. First, the data will provide quantitative to semiquantitative measurements of the subsurface conditions to help guide field decisions regarding the need for continued characterization. Second, the data will provide a mechanism for delineating any vertical and lateral migration of COPCs. Third, the data will be used to aid in the selection of samples to be submitted for laboratory analysis.

Surveying will be conducted to locate each push and sample location. This ensures the extent of migration has been adequately delineated.

\subsubsection{Environmental Soil Samples}

Environmental soil samples will be collected using the CPT and/or sonic drilling at intervals representing the increased levels of COPCs found and those representing evidence of migration of COPCs beyond the boundaries of the CWD. These samples represent confirmatory analyses for the in situ sampling field analytical methods. Soil samples will be collected using lined barrels on the CPT or core barrels. Soil samples will also be collected from the backhoe bucket following the limited excavation activity at the south "bottle" pit. All equipment which contacts soil to be sampled will be decontaminated in accordance with written and approved procedures. Core barrels will be decontaminated prior to each sampling event to minimize the potential for cross-contamination.

Soil samples will be collected with highest priority given to those that will be analyzed for VOCs. Soil samples for laboratory analysis will be collected from selected locations based on a minimum of 20 percent of the number of in situ sampling locations. Additional samples may be submitted to the laboratory at the discretion of the Site Supervisor.

The analytes, analytical methods, and associated QC ranges for precision and accuracy of the samples submitted to the laboratory are specified in Table 4-1. Records will be maintained for the geotechnical data, field analytical measurements, and all other relevant data obtained during each push. Pertinent and required sampling information (e.g., date, time, sample interval) for the soil samples collected will be documented in accordance with the Industrial Sites QAPP (DOE/NV, 1996b). Approved chain of custody procedures will be followed to ensure sample integrity. 


\subsubsection{Geotechnical Samples}

The geotechnical samples will be acquired from two pushes at CWD\#1 and from one push at CWD\#2. At CWD\#1, geotechnical samples will be acquired from the disposal area in the vicinity of the trestle and from a trench in the vicinity of R-MAD-West. At CWD\#2, geotechnical samples will be acquired from a borehole adjacent to or within the waste trench. An off-site laboratory will perform the analysis of geotechnical parameters listed in Table 4-2. The methods shown are minimum standards; other equivalent or superior testing methods may be used.

Table 4-2

Geotechnical Analyses

\begin{tabular}{|c|c|}
\hline Analysis & Method \\
\hline \hline Initial moisture content & ASTM $^{\mathrm{a}}$ D 2216 \\
\hline Dry bulk density & EM $^{\mathrm{b}}-1110-2-1906$ \\
\hline Calculated porosity & EM-1110-2-1906 \\
\hline Saturated/unsaturated hydraulic conductivity & ASTM D 5084 \\
\hline Particle-size distribution & ASTM D 422 \\
\hline Water-release (moisture retention) curve & ASTM D 3152 \\
\hline
\end{tabular}

${ }^{a}$ American Society for Testing and Materials (ASTM, 1996)

${ }^{b}$ U.S. Army Corps of Engineering (USACE, 1970)

\subsubsection{Background Samples}

Background samples will be collected from a background location at each CWD in areas not known to have been disturbed by previous CWD operations. Data from the background locations will be collected in the same manner as the data collection scheme described in Section 4.1.2 of this CAIP. Background information will be used in the CADD to evaluate the significance of the site data and to support the corrective action for this CAU.

\subsubsection{Quality Control Samples}

Samples will be collected as required by the Industrial Sites QAPP (DOE/NV, 1996b). These samples will include trip blanks, equipment blanks, field blanks, field duplicates, and matrix spike and matrix spike duplicate (MS/MSD) samples. Except for trip blanks, all QC samples will be 
analyzed for applicable parameters in Table 4-1. Trip blanks will only be analyzed for VOCs. One set of QC samples will be collected for each CWD. Additional QC samples may be submitted at the discretion of the Site Supervisor. 


\subsection{Waste Management}

Management of investigation-derived waste (IDW) will be based on regulatory requirements, field observations, field screening, and the results of laboratory analysis of CAU 143 investigation samples. Decontamination activities will be performed according to approved contractor procedures as specified in the field sampling instructions and as appropriate for the COPCs likely to be identified within the CWDs.

Waste, other than soil, is potentially contaminated waste only by virtue of contact with potentially contaminated media. Therefore, sampling and analysis of IDW, separate from analyses of site characterization samples, will not be required. The data generated as a result of field screening and soil sampling during site characterization will be used to assign the appropriate waste type (i.e., sanitary, hazardous, low-level radioactive waste [LLW], or mixed waste) to the IDW with the exception noted in Section 5.3.

Sanitary, hazardous, radioactive, and/or mixed waste, if generated, will be managed and disposed of in accordance with DOE orders, U.S. Department of Transportation (DOT) regulations, RCRA regulations, State of Nevada requirements and agreements and permits between DOE and NDEP.

In the following sections, operational requirements are provided for managing sanitary, hazardous, LLW, and mixed wastes. However, when the waste is initially generated, it will be managed according to mixed waste requirements until laboratory analyses are received and a final waste determination is made.

\subsection{Waste Minimization}

Corrective action investigation activities have been planned to minimize IDW generation.

Decontamination activities are planned to minimize the use of rinsate; decontamination materials will consist of detergent, water, and wipes. Disposable sampling equipment, decon rinsate, and personal protective equipment (PPE) will be segregated to the greatest extent possible to minimize the generation of hazardous, radioactive, and/or mixed waste. 


\subsection{Potential Waste Streams}

Historical records and process knowledge do not indicate that hazardous materials were disposed of at the CWDs. Wastes generated during the investigation activities will include the following:

- Potentially contaminated disposable sampling equipment (e.g., plastic, paper, sample containers, aluminum foil, spoons, scoops, bowls)

- PPE

- Decontamination rinsate

- Soil

The waste will be managed as two waste streams, and additional segregation will occur within each waste stream based on sample location. Waste will be traceable to its source, field screening measurements, and to individual samples.

\subsection{Investigation-Derived Waste Management}

To allow for the segregation of radioactive and nonradioactive waste and materials, radiological swipe surveys may be conducted on reusable sampling equipment and the PPE and disposable sampling equipment waste streams exiting from within the controlled area. Removable contamination limits, as defined in Table 2-2 of the Nevada Test Site/Yucca Mountain Radiological Control Manual (DOE/NV, 1996c), shall be used to determine if such materials may be declared nonradioactive. Once a radioactive or nonradioactive waste determination has been made for a particular waste stream, a sanitary or hazardous waste determination will be made. The final disposition of such wastes will be determined by evaluating the analytical results of acquired soil samples. Management requirements for sanitary, low-level, hazardous, or mixed wastes are discussed further in the following sections.

\subsubsection{Sanitary Wastes}

Sanitary waste generated outside the controlled area will be contained in plastic bags and will be transported to a solid waste management unit. Sanitary waste generated within the controlled area will be swiped to determine if the removable contamination is under the limits defined in Table 2-2 of 
the Radiological Control Manual (DOE/NV, 1996c). Analytical results from the swipe surveys will be used for determining if removable materials will be declared nonradioactive, and analytical results from field screening measurements will be used for determining if the materials will be declared sanitary.

\subsubsection{Low-Level Radioactive Waste}

Low-level radioactive waste, if generated, will be managed in accordance with the contractor-specific waste certification program plan and the Nevada Test Site Waste Acceptance Criteria (NTSWAC) (DOE/NV, 1997b). Waste containers containing PPE, disposable sampling equipment, soil, and/or rinsate (when full) shall be staged at a designated Radioactive Materials Area pending certification and disposal under NTSWAC requirements (DOE/NV, 1997b). Waste containers shall be labeled "Caution Radioactive Material Pending Analysis." All containers shall be locked or fitted with tamper-indicating devices (TIDs). Traceability shall be maintained by assigning unique waste tracking numbers to each container and by maintaining records that trace the IDW back to the original sampling locations.

The PPE and disposable sampling equipment shall be placed in clear plastic bags marked with the date and an associated borehole number. The bags will be tagged with a contractor-specific waste tracking tag and will be logged in the contractor-specific waste management logbook.

Rinsate shall be collected in containers that meet DOT specifications (49 Code of Federal Regulations [CFR] 172) (CFR, 1997) pending further treatment. Rinsate may be analyzed separately in order to determine final disposition.

\subsubsection{Hazardous Waste}

Suspected hazardous waste, if encountered, will be managed in accordance with RCRA and State of Nevada hazardous waste management regulations, interpreted as follows. Suspected hazardous waste will be placed in containers that meet DOT specifications (49 CFR 172) (CFR, 1997) and will be locked or fitted with TIDs. The IDW shall be containerized in compliance with Subpart CC of 40 CFR 265 (Elsevier, 1998), and the containers shall be compatible with the waste in accordance with the requirements of 40 CFR 265.172 (Elsevier, 1998). Incompatible waste is not expected to be 
generated; however, if incompatible waste is encountered in the field, it will be managed in accordance with 40 CFR 265.177 (Elsevier, 1998) (i.e., shall not be placed in the same container), and separated such that in the event of a spill, leak, or release, incompatible wastes will not contact one another. Containers shall be handled and inspected in accordance with the requirements of 40 CFR 265.173 and 174, respectively (Elsevier, 1998).

Hazardous waste shall be characterized in accordance with the requirements of 40 CFR 261 (Elsevier, 1998). Characterization will be based on laboratory results from soil sampling. Containers containing IDW pending characterization will be marked with the words "Hazardous Waste Pending Analysis" until regulatory status can be determined through interpretation and evaluation of laboratory results. The IDW shall be traceable to its source and/or samples considered analogous to the IDW (such as PPE associated with a sample). Traceability shall be maintained by assigning unique waste tracking numbers to each container and by maintaining records that trace the IDW back to the samples. After receipt of analytical results, hazardous wastes, if identified, will be labeled and marked in accordance with the requirements of 40 CFR 262.32 (Elsevier, 1998) and State of Nevada requirements, including writing the EPA hazardous waste number on the hazardous waste label.

Alpha and gamma spectroscopy are included in the required site characterization analyses to determine if the waste will meet the Nevada Test Site Performance Objectives for Certification of Nonradioactive Hazardous Waste, Revision 0 (BN, 1995). These analyses are included in the event the waste generated during site characterization is determined to be hazardous.

Hazardous waste management methods, including the establishment of Satellite Accumulation Areas or a 90-day Hazardous Waste Accumulation Area, will be employed to temporarily accumulate IDW, pending characterization. These methods will be appropriate for the amount of waste being accumulated and will be in compliance with applicable State of Nevada and federal requirements.

Suspected hazardous waste will be accumulated at or near the site of generation for up to 90 days in accordance with 40 CFR 262.34 (Elsevier, 1998). Prior to or on the 90th day of accumulation, as specified in 40 CFR 262.34 (a) (Elsevier, 1998), hazardous waste will be shipped by a licensed/permitted hazardous waste transporter to a permitted treatment storage and disposal facility. If hazardous waste must remain on-site for longer than 90 days due to unforeseen, temporary, and uncontrollable circumstances, a letter requesting an extension for up to 30 days will be sent to the 
NDEP in accordance with 40 CFR Part 262.11(b) (Elsevier, 1998). A copy of the uniform hazardous waste manifest shall be provided to the State of Nevada.

\subsubsection{Mixed Wastes}

Mixed waste, if generated, shall be managed in accordance with RCRA (40 CFR 262)

(Elsevier, 1998) and State of Nevada NAC 444 (NAC, 1990). These regulations, as well as DOE requirements for radioactive waste, are interpreted as follows. Where there is a conflict in regulations or requirements, the most stringent shall apply. For example, the 90-day accumulation time limit and weekly inspections per RCRA regulations will be applied to mixed waste even though it is not required for radioactive waste. Conversely, while RCRA does not require documented traceability, the waste acceptance program for LLW does; therefore, traceability shall be documented as described in Section 5.3.2.

In general, mixed waste shall be managed in the same manner as hazardous waste, with added mandatory radioactive waste management program requirements. Suspected mixed waste will be managed in accordance with applicable regulations and requirements and will be labeled "Hazardous Waste Pending Analysis" pending characterization and confirmation of its regulatory status. However, once the waste determination is made, or the RCRA 90-day time requirement draws to an end, mixed waste shall be transported via a permitted hazardous waste hauler to the NTS transuranic waste (TRU) storage pad for storage pending treatment or disposal. Mixed waste with hazardous waste constituents that are below land-disposal restrictions may be disposed of at the Area 5 Radioactive Waste Management Site.

Mixed waste not meeting land disposal restrictions will require development of a treatment plan under the requirements of the Mutual Consent Order between DOE and the State of Nevada (NDEP, 1995). 


\subsection{Duration and Records Availability}

Corrective Action Unit 143 schedule and records availability are provided in this section.

\subsection{Duration}

After the submittal of the Final CAIP for CAU 143 to NDEP (FFACO milestone date of, the following is a tentative schedule of activities [in calendar days]):

- Day 0: Preparation for field work will begin.

- Day 60: The field work, including field screening and sampling, will begin.

- Day 100: The field work will be completed.

- Day 155: The quality-assured laboratory analytical sample data will be available for review.

- The FFACO date for the CADD is July 7, 2000.

\subsection{Records Availability}

The NDEP maintains the official Administrative Record for all activities conducted under the auspices of the FFACO. This document is available in the DOE Public reading rooms located in Las Vegas and Carson City, Nevada or by contacting the DOE Project Manager. 


\subsection{References}

Adams, Stephen R. IT Corporation. 1998. Memo to Robert McCall regarding "Methodology for Determining Preliminary Action Levels for CAU 407, the Roller Coaster RADSAFE Area," 16 June. Las Vegas, NV.

AEC, see U.S. Atomic Energy Commission.

ASTM, see American Society for Testing and Materials.

American Public Health Association. 1998. Standard Methods for the Examination of Water and Wastewater. Washington, DC.

American Society for Testing and Materials. 1996. Annual Book of ASTM Standards, Sections 04.08 and 04.09. In Construction. Philadelphia, PA.

Atlan-Tech. 1992. Environmental Monitoring Report for the Proposed Ward Valley California LLRW Facility. Rosewall, GA: Atlan-Tech Inc.

BN, see Bechtel Nevada.

Bechtel Nevada. 1995. Nevada Test Site Performance Objective for Certification of Nonradioactive Hazardous Waste. Las Vegas, NV.

Bechtel Nevada. 1997. Engineering Drawings Index Standard Report. Las Vegas, NV.

CFR, see Code of Federal Regulations.

Code of Federal Regulations. 1997. 49 CFR Part 172, "Hazardous Materials Table, Special Provisions, Hazardous Materials Communications, Emergency Response Information, and Training Requirements.” Washington, DC: U.S. Government Printing Office.

DOE, see U.S. Department of Energy.

DOE/NV, see U.S. Department of Energy, Nevada Operations Office.

DRI, see Desert Research Institute.

Desert Research Institute. 1996. A Historical Evaluation of the Engine Maintenance Assembly and Disassembly Facility, Area 25, Nevada Test Site, Nye County, Nevada, Cultural Resources Reconnaissance Short Report SR082696-1, NTS Project 964825. Las Vegas, NV.

EG\&G. 1964. Aerial photograph of R-MAD (6411720), Nellis Air Force Base, NV: BN Remote Sensing Laboratory Photograph Library. Las Vegas, NV. 
EG\&G. 1966. Photograph of Burial Pit R-MAD Hot Dump (664321), Nellis Air Force Base, NV: BN Remote Sensing Laboratory Photograph Library.

EG\&G. 1968. Aerial photograph of E-MAD (6811-19-41). Nellis Air Force Base, NV: BN Remote Sensing Laboratory Photograph Library.

EG\&G. 1988. Aerial photograph of R-MAD CWD \#1 (8811-65). Nellis Air Force Base, NV:

BN Remote Sensing Laboratory Photograph Library.

Elsevier Inc., see Elsevier Science, Inc.

Elsevier Science, Inc. 1998. RCRA Regulations and Keyword Index, 1998 Edition. New York, NY.

EPA, see U.S. Environmental Protection Agency.

Fauver, D.N. 1986. Hazardous Waste Installation Assessment Report, DOE/NV10327--23. Las Vegas, NV: REECo.

FFACO, see Federal Facility Agreement and Consent Order.

Federal Facility Agreement and Consent Order. 1996, as amended. Agreed to by the State of Nevada, the U.S. Department of Energy, and the U.S. Department of Defense.

Geary, K. (PEER Consultants). 1998. On-site interview with DOE/NV, NDEP, Bechtel Nevada, and IT Corporation regarding historic operations at R-MAD/E-MAD CWDs, 21 January. Nevada Test Site, NV.

Hale, G.S., and C.L. Westenburg. 1995. Selected Ground-Water Data for Yucca Mountain Region, Southern Nevada and Eastern California, Calendar Year 1993, Open-File Report 95-158. Carson City, NV.

IT, see IT Corporation.

IT Corporation. 1993, as amended. ITLV Program Procedures Manual, Standard Quality Practices. Las Vegas, NV.

IT Corporation. 1998. Preliminary Assessment for CAU No. 143: Area 25 Contaminated Waste Dumps, CAS No. 25-23-09 R-MAD Contaminated Waste Dump \#1, Nevada Test Site, Nevada, ITLV/13052-011. Las Vegas, NV.

Kreiger, H.L., and E.L. Whittaker. 1980. Prescribed Procedures for Measurement of Radioactivity in Drinking Water, EPA-600/4-80-032. Cincinnati, OH: U.S. Environmental Protection Agency.

Liebendorfer, P. (NDEP). 1998 Letter to M.O. Giblin, DOE/NV, about transfer of CAU 143 from Appendix II to Appendix III of the FFACO, 13 February. Carson City, NV. 
McArthur, R.D., and F.L. Miller. 1989. Off-Site Radiation Exposure Review Project (ORERP), Phase II Soil Program, DOE/NV10384--23. Las Vegas, NV: Desert Research Institute.

Miller, M.G. 1984. Nevada Test Site, Area 25 Radiological Survey and Cleanup Project 1974-1983, DOE/NV10327--5, Rev. 1. Las Vegas, NV: REECo.

NAC, see Nevada Administrative Code.

NAS, see National Academy of Sciences.

National Academy of Sciences. 1962. Nuclear Science Series, NAS-NS3050. Washington, DC.

Nevada Administrative Code. 1990. NAC444.940 - NAC444.9555, "Solid Waste Disposal." Carson City, NV: Nevada Division of Environmental Protection.

Nevada Administrative Code. 1998a. NAC445A.226 - NAC445A.22755, "Corrective Action Regulations." Carson City, NV: Nevada Division of Environmental Protection.

Nevada Administrative Code. 1998b. NAC445A.2272, "Contamination of Soil: Establishment of Action Levels." Carson City, NV: Nevada Division of Environmental Protection.

Nevada Administrative Code. 1998c. NAC459.9973, "Presence of excessive petroleum in soil: Evaluation; assessment of risk; corrective action." Carson City, NV: Nevada Division of Environmental Protection.

NDEP, see Nevada Division of Environmental Protection.

Nevada Division of Environmental Protection. 1995. "Mutual Consent Agreement Between the State of Nevada and the Department of Energy for the Storage of Low-Level Land Disposal Restricted Mixed Waste," 6 June. Carson City, NV.

REECo, see Reynolds Electrical \& Engineering Company, Inc.

Reynolds Electrical \& Engineering Company, Inc. 1986. Nevada Test Site Underground Contaminants. Las Vegas, NV.

Rush, F.E. 1968. Index of Hydrographic Areas in Nevada, Department of Conservation and Natural Resources Water Resources-Information Series Report 6, State of Nevada. Carson City, NV.

SAIC, see Science Applications International Corporation.

Sanders, F.W. Los Alamos Scientific Laboratory. 1965a. Interoffice Memorandum to Philip Lee (LASL) regarding, "Health Physics Advisor's Report for Week Ending 3-28-65." 29 March. Mercury, NV: DOE/NV Archives and Records Center. 
Sanders, F.W. Los Alamos Scientific Laboratory. 1965b. Interoffice Memorandum to Philip Lee (LASL) regarding, "Health Physics Advisor's Report for Week Ending 4-4-65." 05 April. Mercury, NV: DOE/NV Archives and Records Center.

Science Applications International Corporation. 1998. First Quarter 1998 Surface Geophysical Survey Report, Contaminated Waste Dumps, EMAD and RMAD. Prepared for IT Corporation. Middletown, PA: R.E. Wright Environmental, Inc.

Science Applications International Corporation. 1999. Second Quarter 1999 Surface Geophysical Survey Report, Reactor Maintenance Assembly and Disassembly (RMAD) Area, Corrective Action Site 25-23-09 at the Nevada Test Site, Nye County Nevada. Prepared for IT Corporation. Las Vegas, NV.

Tinney, J.F. and Wheeler, D.L. 1999. Radiological Calculations for Corrective Action Unit 143: Area 25 Contaminated Waste Dumps, Nevada Test Site. Las Vegas, NV: U.S. Department of Energy, Nevada Operations Office.

USACE, see U.S. Army Corps of Engineers.

U.S. Army Corps of Engineers. 1970. "Laboratory Soils Testing.” In Engineering Manual 1110-2-1906, Appendix II. Washington, DC.

U.S. Atomic Energy Commission. 1969. NRDS Master Plan, 1969-1970. Washington, DC: Space Nuclear Propulsion Office.

U.S. Department of Energy. 1980. Decommissioning of the Nuclear Rocket Development Station, Area 25, Nevada Test Site. Las Vegas, NV: Nevada Operations Office.

U.S. Department of Energy. 1992. Environmental Measurements Laboratory Procedures Manual, HASL-300, 27th Edition, Vol. 1. New York, NY.

U.S. Department of Energy, Nevada Operations Office. 1969a. Weekly activity report from the Area Monitoring Department. 14 February. Las Vegas, NV: Archives and Records Center.

U.S. Department of Energy, Nevada Operations Office. 1969b. Weekly activity report from the Area Monitoring Department. 29 March. Las Vegas, NV: Archives and Records Center.

U.S. Department of Energy, Nevada Operations Office. 1969c. Weekly activity report from the Area Monitoring Department. 17 October. Las Vegas, NV: Archives and Records Center.

U.S. Department of Energy, Nevada Operations Office. 1970. Weekly activity report from the Area Monitoring Department. 18 February. Las Vegas, NV: Archives and Records Center.

U.S. Department of Energy, Nevada Operations Office. 1987. Nevada Test Site - Environmental Compliance Atlas, 15 June. Las Vegas, NV. 
U.S. Department of Energy, Nevada Operations Office. 1988a. CERCLA Preliminary Assessment of DOE's Nevada Operations Office Nuclear Weapons Testing Areas, Draft. Las Vegas, NV.

U.S. Department of Energy, Nevada Operations Office. 1988b. Environmental Survey Preliminary Report, Nevada Test Site, Nevada, DOE/EH/OEV-15P. Las Vegas, NV: DOE Environmental, Safety and Health, Office of Environmental Audit.

U.S. Department of Energy, Nevada Operations Office. 1988c. Site Characterization Plan; Yucca Mountain Site, Nevada Research and Development Area, Nevada, DOE/RW-0199, Vols. I \& II, Part A. Las Vegas, NV.

U.S. Department of Energy, Nevada Operations Office. 1994. Project Management Plan, Rev. 0. Las Vegas, NV.

U.S. Department of Energy, Nevada Operations Office. 1996a. Final Environmental Impact Statement for the Nevada Test Site and Off-Site Locations in the State of Nevada, DOE/EIS 0243. Las Vegas, NV.

U.S. Department of Energy, Nevada Operations Office. 1996b. Industrial Sites Quality Assurance Project Plan, Nevada Test Site, Nevada, Rev. 1, DOE/NV--372. Las Vegas, NV.

U.S. Department of Energy, Nevada Operations Office. 1996c. Nevada Test Site/Yucca Mountain Project Radiological Control Manual, Rev. 2. Las Vegas, NV.

U.S. Department of Energy, Nevada Operations Office. 1997a. Decontamination and Decommissioning Subproject Characterization Report for the E-MAD Decontamination Project, Rev. 1. Las Vegas, NV.

U.S. Department of Energy, Nevada Operations Office. 1997b. Nevada Test Site Waste Acceptance Criteria, Rev. 1. Las Vegas, NV.

U.S. Department of Energy, Nevada Operations Office. 1998. Environmental Restoration Project Health and Safety Plan, Rev. 3. Las Vegas, NV.

U.S. Environmental Protection Agency. 1994. Guidance for the Data Quality Objectives Process, EPA QA/G-4. Washington, DC.

U.S. Environmental Protection Agency. 1996. Test Methods for Evaluating Solid Waste, Physical/Chemical Methods, SW-846, 3rd Edition, CD ROM. Washington, DC.

USGS, see U.S. Geological Survey.

U.S. Geological Survey. 1978. "Hydrologic Unit Map, 1978, State of California," Scale 1:500,000. Reston, VA: U.S. Water Resources Division.

U.S. Geological Survey. 1983a. “Jackass Flats Quadrangle, Nevada,” Scale 1:24,000. Reston, VA. 
U.S. Geological Survey. 1983b. "Skull Mountain Quadrangle, Nevada,” Scale 1:24,000. Reston, VA.

Wallace, D.L. Pan American World Airways, Inc. 1965. Letter to the Technical Division Director of the Space Nuclear Propulsion Office regarding, "Contract SNPO-B, Storage of Radioactive Materials and Disposal of Radioactive Wastes." 17 October. Las Vegas, NV: DOE/NV Archives and Records Center. 


\section{Appendix A}

\section{Data Quality Objectives for Corrective Action Investigation Plan for Corrective Action Unit 143}




\section{A.1.0 Introduction}

\section{A.1.1 Problem Statement}

The AEC jointly with NASA initiated the development of nuclear rocket engines in 1959. The program known as Project ROVER operated from 1959 through 1972. During Project ROVER twenty rocket engines were tested. Solid radioactive wastes generated during the program were buried at R-MAD CWD \#1 and at the E-MAD CWD \#2 in Area 25. The wastes are located in trenches, pits, and potentially beneath mounded areas. The focus of this investigation is to characterize and evaluate the nature and extent of contamination in R-MAD-West, R-MAD-East area, one pit south of R-MAD-West, and a trench at E-MAD.

A previous DQO was conducted for CAU 143 and a CAIP was prepared. Prior to starting field activities, additional historical information was obtained which raised concern about the investigative method described in the Revision 0 of the CAIP. Additional historical information suggested that high radiation levels might be present within the area of concern. The field investigation was terminated to reevaluate the original proposed strategy. This revision to the Data Quality Objectives is the product of the additional evaluation.

Purpose: Collect data adequate to close CAU 143 in accordance with the FFACO, NDEP, and DOE requirements potentially as a closure in place.

Conduct a sampling program including (1) in situ sampling and analysis and (2) soil sampling and analysis to evaluate the presence and potential extent of migration of COPCs laterally and vertically.

\section{A.1.2 DQO Kickoff Meeting}

The goal of the DQO process is to establish the quantity and quality of environmental data required to support the corrective action decisions for the CAU. This process will ensure that the information collected will provide sufficient and reliable information to identify, evaluate, and technically defend the chosen corrective action. Unless otherwise required by the results of this DQO and stated in the CAIP, the investigation will adhere to the Industrial Sites Quality Assurance Project Plan (DOE/NV, 1996b). Table A.1-1 lists the proposed participants at the kickoff meeting. 
Table A.1-1

DQO Meeting Participants

\begin{tabular}{||c|c||}
\hline Participant & Affiliation \\
\hline \hline Steve Adams & ITLV \\
\hline Janet Appenzeller-Wing & DOE/NV \\
\hline Brian Perkins & ITLV \\
\hline Sabine Curtis & DOE/NV \\
\hline Mark DiStefano & ITLV \\
\hline Stephen Duce & ITLV \\
\hline Cindy Dutro & ITLV \\
\hline Bob Eastmond & ITLV \\
\hline Dudley Emer & BN \\
\hline David Wheeler & DOE/NV \\
\hline Syl Hersh & ITLV \\
\hline Brad Jackson & ITLV \\
\hline Mike McKinnon & NDEP \\
\hline Kevin Cabble & DOE/NV \\
\hline Jeff Smith & BN \\
\hline Joe Tinney & SAIC \\
\hline
\end{tabular}

ITLV - IT Corporation, Las vegas Office BN - Bechtel Nevada

NDEP - Nevada Division of Environmental Protection SAIC - Science Applications International Corporation DOE/NV - U.S. Department of Energy, Nevada Operations Office 


\section{A.2.0 Conceptual Site Model}

The conceptual site model (Table 3-1) describes the most probable scenario for the current conditions present at CAU 143. The resident waste materials are radioactive products disposed of from nuclear rocket testing in the 1960s and 1970s. Although the products of these disposal activities indicate some surface migration of radioactive contamination from the original material placed in the R-MAD confines, there is no available data to indicate subsurface migration of contamination. These waste materials are made up of discarded contaminated nuclear reactor components or irradiated/ contaminated engine parts and other solid wastes from maintenance and cleanup activities buried in shallow and deep trenches and pits.

The contaminants were released directly to Area 25 surface and subsurface soils as the result of transport, storage, and disposal of used reactor parts. Vertical and lateral migration of radioactive and hazardous contaminants is considered to be limited to the soil surrounding the waste disposal areas. Exact types and quantities of waste are not known. The dimensions of the actual waste areas are not exactly known. The locations of many large metallic waste items are known. The CAU 143 dumps received solid radioactive wastes. Hazardous materials may also have been disposed of in E-MAD and R-MAD dump areas.

Drive over and walkover radiological surveys have been completed and clearly identify surface radiation. Geophysical surveys have been conducted to verify that waste disposal did occur in identified waste disposal areas. The geophysical and historical data surveys were successful in delineating the lateral limits of soil disturbance, landfill activities, and locating where metallic materials were buried. However, the surveys were not capable of consistently defining the depth of soil disturbance and landfill activities. Two additional surveys were performed at E-MAD (CWD \#2) using electrical imaging to assist in defining the size and shape of the waste disposal areas.

There were 20 rocket engines tested in some 30 tests during Project ROVER. Following the nuclear rocket engines tests, the engines and recoverable debris were transported to the R-MAD facility where they were allowed to cool off in a bermed area prior to disassembly. Following 
disassembly, parts scheduled for reuse were stored in various areas of R-MAD (CWD \#1) and generated waste products and discards were placed within a rail car and dumped from a trestle into a discard pit. After 1963, a series of shallow R-MAD west trenches were used for disposal of radioactive materials.

The nuclear fuel rods were removed from the engines after each test and some were transported to LANL for post operational evaluation. Later this post operation was performed at the R-MAD Jr. Hot Cell facility. One-inch sections were reportedly cut from selected fuel rods for isotopic analysis in Jr. Hot Cell. Each analytical sample discarded solution (1-liter for each 1-inch fuel section) was poured into five 1-liter plastic bottles filled with vermiculite for disposal in the waste trenches. There are reports that some reactor engines without the reactor core were stored and may have been buried on site.

Since the Special Nuclear Material $\left({ }^{235} \mathrm{U}\right)$ in the Project ROVER reactor cores was valuable and protected for both safeguards and security concerns, the fuel was removed and transferred off site to Idaho National Environmental Engineering Laboratory (INEEL) for reprocessing. It is highly unlikely that any reactor fuel elements were disposed in CAU 143. There is a strong possibility that small fragments of the Kiwi-TNT reactor and irradiated and contaminated debris are disposed within CAU 143. It is unlikely that significant quantities of uranium are contained within CAU 143 for reasons stated above.

The nuclear engines did generate a large amount of fission products that initially included many radioactive isotopes. Most of these isotopes had short-lived half-lives and decayed quickly. The decay process has reduced the calculated exposure levels by several orders of magnitude in the 35 years since the reactors were first tested. The only fission product observed at CAU 143 is ${ }^{137} \mathrm{Cs}$ which can be detected with gamma instruments, and ${ }^{90} \mathrm{Sr}$, a beta-emitting radionuclide which can be implied from the ${ }^{137} \mathrm{Cs}$ measurements.

The primary activation products generated during the rocket testing and likely to still be present include ${ }^{60} \mathrm{Co},{ }^{152} \mathrm{Eu}$, and ${ }^{94} \mathrm{Nb}$. Cobalt-60 was produced through neutron activation of stainless steel and has been detected in small quantities in the landfill trenches. Europium-152 is an activation product resulting from neutron activation of soil. Europium-152 has a 13.5-year half life and it is reasonable to assume that some of the activated soil may have been placed in the trenches during 
cleanup operations. Another activation product is ${ }^{94} \mathrm{Nb}$. To reduce erosion and corrosion of fuel from the high velocity hydrogen coolant gas, niobium was used as a cooling channel liner in the graphite rods.

ROVER reactor fuel processed at INEEL indicated the presence of ${ }^{235} \mathrm{U},{ }^{137} \mathrm{Cs}$, and ${ }^{94} \mathrm{Nb}$. The ${ }^{90} \mathrm{Sr}$ concentration can be approximated from the ${ }^{137} \mathrm{Cs}$ concentration. Small quantities of ${ }^{239} \mathrm{Pu}$ were also identified. Calculations of radionuclides associated with the ROVER program tests are reported in Radiological Calculations for Corrective Action Unit 143: Area 25 Contaminated Waste Dumps, Nevada Test Site (Tinney and Wheeler, 1999).

This CAU will be investigated based on the DQOs developed by representatives of the NDEP and DOE/NV. The investigation will determine if potential contaminants have migrated beyond previous boundaries. Information obtained will determine the extent and the impact (if any) to the adjacent surroundings and underlying soil to affect a resolution. Closure will be guided by the NDEP and DOE requirements as outlined in Federal Facility Agreement and Consent Order (FFACO, 1996). 


\section{A.3.0 Contaminants of Concern}

The COPCs are the contaminants that were released directly to CAU 143 surface and subsurface soils as the result of transport, storage, and disposal used reactor parts. Vertical and lateral migration of radioactive and hazardous contaminants is considered to be limited to the soil surrounding the waste disposal areas. Exact types and quantities of waste are not known. The dimensions of the actual waste areas are not exactly known. The locations of many large metallic waste items are known. The CAU 143 dumps received solid radioactive wastes. Contaminants of potential concerns are identified in Table 3-1.

Previous sampling identified ${ }^{137} \mathrm{Cs}$ and ${ }^{60} \mathrm{Co}$ in pits and trenches in R-MAD and E-MAD. Activation products suspected as present in the CAU include ${ }^{60} \mathrm{Co},{ }^{152} \mathrm{Eu}$, and ${ }^{94} \mathrm{Nb}$. Mixed fission products and potential fuel particles that may be found in the Unit include ${ }^{137} \mathrm{Cs},{ }^{90} \mathrm{Sr},{ }^{239} \mathrm{Pu},{ }^{234} \mathrm{U}$ and ${ }^{235} \mathrm{U}$.

Hazardous materials may have been disposed of in E-MAD and R-MAD Dumps. 
Table A.3-1

Contaminants of Potential Concern

\begin{tabular}{|c|c|c|c|c|}
\hline Potential & Comments & $\begin{array}{l}\text { Field Screening } \\
\text { Methods }\end{array}$ & Field Screening Level & $\begin{array}{c}\text { Preliminary Remediation } \\
\text { Goals/Action Level }\end{array}$ \\
\hline Total VOCs & $\begin{array}{l}\text { Not expected; however, } \\
\text { activities indicate possibility } \\
\text { of some VOC's may be } \\
\text { present }\end{array}$ & CPT VOC detectors & $\begin{array}{c}20 \text { ppm or } 2.5 \text { times } \\
\text { background (use greater } \\
\text { value) }\end{array}$ & $\mathrm{PRG}^{\mathrm{a}} \mathrm{NAC} 445 \mathrm{~A}^{\mathrm{b}}$ \\
\hline Total SVOCs & Not expected & NA & NA & $\mathrm{PRGs}^{\mathrm{a}} \mathrm{NAC} 445 \mathrm{~A}^{\mathrm{b}}$ \\
\hline Total RCRA Metals & Unknown & NA & NA & $\mathrm{PRGs}^{\mathrm{a}} \mathrm{NAC} 445 \mathrm{~A}^{\mathrm{b}}$ \\
\hline $\begin{array}{c}\text { Total pesticides, } \\
\text { total herbicides and } \\
\text { polychlorinated biphenyls }\end{array}$ & Not expected & NA & NA & $\mathrm{PRGs}^{\mathrm{a}} \mathrm{NAC} 445 \mathrm{~A}^{\mathrm{b}}$ \\
\hline $\begin{array}{c}\text { Total petroleum hydrocarbon } \\
\text { (gasoline-and diesel-range } \\
\text { organic) }\end{array}$ & Not expected & NA & NA & $\begin{array}{c}100 \text { ppm } \\
\text { NAC } 445 A^{b}\end{array}$ \\
\hline Radionuclides & $\begin{array}{c}\text { Gross alpha, gross beta; } \\
{ }^{60} \mathrm{Co},{ }^{137} \mathrm{Cs} \text { in previous } \\
\text { samples; activation products } \\
{ }^{60} \mathrm{Co},{ }^{94} \mathrm{Nb} \text {; potential fission } \\
\text { products }{ }^{137} \mathrm{Cs},{ }^{90} \mathrm{Sr},{ }^{239} \mathrm{Pu} \text {, } \\
\text { and fuel particles }{ }^{234} \mathrm{U},{ }^{235} \mathrm{U} \text {, } \\
\text { and }{ }^{94} \mathrm{Nb}\end{array}$ & $\begin{array}{c}\text { Gamma Spectrometry, } \\
\text { Electra }^{\mathrm{TM}} \text { Alpha/Beta Nal } \\
\text { detector, and Alpha }^{\text {Spectrometry }}\end{array}$ & $\begin{array}{l}\text { Mean environmental } \\
\text { background }+2 \text { times } \\
\text { standard deviation }\end{array}$ & $\begin{array}{c}\text { The preliminary action levels } \\
\text { for radionuclides are } \\
\text { isotope-specific and are } \\
\text { defined as the maximum } \\
\text { concentration for that isotope } \\
\text { found in environmental } \\
\text { samples taken from } \\
\text { undisturbed background } \\
\text { locations. }\end{array}$ \\
\hline
\end{tabular}

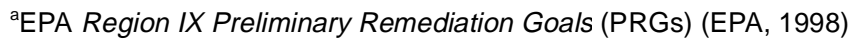

bNDEP Nevada Administrative Code (NAC, 1998)

$\mathrm{NA}=$ Not Applicable 


\section{A.4.0 Decisions}

\section{A.4.1 Decisions}

Decisions to be made by conducting both in situ and laboratory analytical sampling approach to the investigation include:

- Do contaminant concentrations exceed screening levels and PALs as specified in Table A.3-1?

- Are COPCs present at target locations?

- Have COPCs migrated beyond the initial disposal sites and, if so, to what extent?

- Are data sufficient to allow the development and evaluation of a corrective action?

Table A.4-1 summarizes existing data and data gaps. 
Table A.4-1

\section{General Strategies}

(Page 1 of 2)

\begin{tabular}{|c|c|c|c|c|}
\hline Decision & Input & Existing Data & Data Gap & Strategy \\
\hline $\begin{array}{l}\text { The geophysical } \\
\text { properties of the } \\
\text { subsurface being } \\
\text { investigated }\end{array}$ & Geotechnical Data & $\begin{array}{c}\text { Size and location of trenches are estimated from } \\
\text { geophysical survey; exact dimension of cover material } \\
\text { and waste disposal area at each CPT location is } \\
\text { estimated }\end{array}$ & $\begin{array}{l}\text { Locate base of cover, } \\
\text { and bottom of waste } \\
\text { disposal area at each } \\
\text { CPT location }\end{array}$ & $\begin{array}{l}\text { Collect geotechnical and geophysical } \\
\text { data for each CPT location. }\end{array}$ \\
\hline $\begin{array}{l}\text { Presence of } \\
\text { Contamination }\end{array}$ & $\begin{array}{l}\text { Potential contaminant } \\
\text { migration }\end{array}$ & $\begin{array}{l}\text { Potential radiological and hazardous contamination; } \\
\text { VOC's will be analyzed by soil/gas sampling for } \\
\text { verification of hazardous materials }\end{array}$ & $\begin{array}{l}\text { Actual presence of } \\
\text { radioactive and VOC } \\
\text { contaminants }\end{array}$ & $\begin{array}{l}\text { Use CPT to identify radioactive and } \\
\text { VOC contamination; at bias locations, } \\
\text { collect gamma spec and VOC } \\
\text { analysis data. }\end{array}$ \\
\hline $\begin{array}{l}\text { Are contaminants } \\
\text { present above } \\
\text { screening levels } \\
\text { beneath trench bottom } \\
\text { and/or outside of trench } \\
\text { boundaries at CAU } 143\end{array}$ & $\begin{array}{l}\text { Potential contaminant } \\
\text { concentrations }\end{array}$ & Gamma activity and VOC concentrations are not known & $\begin{array}{l}\text { COPC concentrations } \\
\text { exceeding screening } \\
\text { levels }\end{array}$ & $\begin{array}{c}\text { Survey using CPT to define gamma } \\
\text { activity and soil/gas concentrations; at } \\
\text { bias locations, collect gamma spec } \\
\text { and VOC data. }\end{array}$ \\
\hline \multirow{2}{*}{$\begin{array}{l}\text { Are contaminants above } \\
\text { background levels }\end{array}$} & \multirow{2}{*}{$\begin{array}{l}\text { Field analytical results } \\
\text { and laboratory data } \\
\text { from background } \\
\text { (uncontaminated) } \\
\text { area(s) }\end{array}$} & $\begin{array}{l}\text { Available data on radioactivity and VOCs from other } \\
\text { Area } 25 \text { projects }\end{array}$ & $\begin{array}{l}\text { Insufficient subsurface } \\
\text { background data }\end{array}$ & $\begin{array}{l}\text { Collect geotechnical, radiological, and } \\
\text { VOC data from CPT push(es) at } \\
\text { background locations for each CWD. }\end{array}$ \\
\hline & & No subsurface data in the vicinity of either CWD & $\begin{array}{l}\text { Lack of subsurface } \\
\text { background data }\end{array}$ & $\begin{array}{l}\text { Collect geotechnical, radiological, and } \\
\text { VOC data from CPT push(es) at } \\
\text { background locations for each CWD. }\end{array}$ \\
\hline \multirow[b]{2}{*}{$\begin{array}{l}\text { Are potential } \\
\text { contaminants migrating }\end{array}$} & \multirow[b]{2}{*}{$\begin{array}{l}\text { Potential contaminant } \\
\text { migration and } \\
\text { distribution }\end{array}$} & $\begin{array}{l}\text { Lateral contaminant migration may extend beyond the } \\
\text { area boundaries into surrounding soil }\end{array}$ & Lateral extent of COPCs & $\begin{array}{l}\text { To define the lateral extent of } \\
\text { contamination, the CPT will step out } \\
10 \mathrm{ft} \text { beyond the point where } \\
\text { background readings are obtained. }\end{array}$ \\
\hline & & $\begin{array}{l}\text { Vertical contaminant migration may extend beyond the } \\
\text { trench bottoms into surrounding soil }\end{array}$ & Vertical extent of COPCs & $\begin{array}{l}\text { To define the vertical extent of } \\
\text { contamination, continue CPT until } \\
10 \mathrm{ft} \text { beyond the point to which } \\
\text { background readings are obtained, or } \\
10 \mathrm{ft} \text { beyond waste disposal area; if } \\
\text { contamination extends beyond CPT } \\
\text { vertical limit, the local investigation } \\
\text { will use rotosonic drilling. }\end{array}$ \\
\hline
\end{tabular}


Table A.4-1

\section{General Strategies}

(Page 2 of 2 )

\begin{tabular}{|c|c|c|c|c|}
\hline Decision & Input & Existing Data & Data Gap & Strategy \\
\hline \multirow{3}{*}{$\begin{array}{l}\text { Data available to } \\
\text { support closure }\end{array}$} & Closure in place & $\begin{array}{l}\text { Potential for RCRA constituents; assume industrial } \\
\text { PRGs per NAC 445A (NAC, 1998); assume use } \\
\text { restrictions with signs and fencing as needed }\end{array}$ & $\begin{array}{l}\text { Concentration of } \\
\text { contaminants }\end{array}$ & $\begin{array}{l}\text { Collect in situ and laboratory field } \\
\text { data; compare results to screening } \\
\text { levels and PALs; prepare CADD. }\end{array}$ \\
\hline & $\begin{array}{l}\text { Closure in place with } \\
\text { engineering controls }\end{array}$ & $\begin{array}{l}\text { Potential for RCRA constituents; assume industrial } \\
\text { PRGs per NAC 445A (NAC, 1998); assume use } \\
\text { restrictions with signs and fencing as needed }\end{array}$ & $\begin{array}{l}\text { Concentration of } \\
\text { contaminants }\end{array}$ & $\begin{array}{l}\text { Collect in situ and laboratory field } \\
\text { data; compare results to screening } \\
\text { levels and PALs; prepare CADD. }\end{array}$ \\
\hline & $\begin{array}{l}\text { Closure in place with } \\
\text { engineering controls } \\
\text { and/or continued } \\
\text { monitoring }\end{array}$ & $\begin{array}{l}\text { Potential for RCRA constituents; assume industrial } \\
\text { PRGs per NAC 445A (NAC, 1998); assume use } \\
\text { restrictions with signs and fencing as needed }\end{array}$ & $\begin{array}{l}\text { Concentration of } \\
\text { contaminants }\end{array}$ & $\begin{array}{l}\text { Collect in situ and laboratory field } \\
\text { data; compare results to screening } \\
\text { levels and PALs; prepare CADD. }\end{array}$ \\
\hline
\end{tabular}




\section{A.5.0 Investigative Strategy}

IT Corporation will use a CPT to perform in situ measurements of gamma radiation, radionuclides, and VOCs at approximately 40 locations and to collect soil samples from biased locations based on at least 20 percent of the number of in situ sample locations in CAU 143. Preliminary locations are shown in Figures 4-2 and 4-3. The CPT equipped with a sodium iodide scintillation counter will be used to measure radiation and radionuclides using gamma-ray spectrometry. The CPT will also be used to perform continuous logging of soil gas using onboard PID and FID and VOC analysis using a GC/MS system. These in situ field measures and the results of laboratory analyses from soil samples will assist in determining the closure approach for CAU 143. The collective results of the geotechnical information, gamma survey data, and VOC soil gas analyses will be compared to screening levels and soil sample analytical results will be compared to in situ field data and the PALs (Table A.3-1).

The field sampling activities will occur at biased locations selected on the basis of process knowledge, geophysical data, and in situ gamma and VOC data to confirm or refute the conceptual model. Initial bias CPT sampling locations will be identified prior to field mobilization and will be adjacent to anomalies and associated disposal areas identified from the geophysical and existing radiological information.

The following activities are associated with the scope of work:

- Bias CPT sampling locations will be identified prior to field mobilization and will be adjacent to anomalies and along disposal areas identified from the geophysical and radiological surveys maps.

- The CPT will be calibrated prior to sampling at the site in accordance with manufacturer's procedures.

- The scintillation detector will be performance tested on-site.

- A minimum of two background push locations will be sampled for radiological measurements and VOC concentrations.

- Sampling will begin within CWD \#1 in the South Pit "bottle area" and may include other areas of known elevated radioactivity such as near PVC-4. 
- The South Pit (bottle area) will also be sampled via excavation to obtain confirmation of the nature of waste disposition at that location.

- Collection of CPT lithological data will be continuous and will be used to determine when the bottom of the cover material is reached, and delineate the bottom and outer perimeter of the waste disposal unit.

- Soil samples will be obtained for contaminant and soil physical analysis using the CPT and a rotosonic drill rig as directed by the IT lead scientist.

- Count rates will be displayed and collected continuously and will be used to determine gamma presence and potential migration. Gamma spectral measurements will be performed at locations determined by the IT lead scientist.

The QA/QC checks for the scintillation counter and multi-channel analyzer will be performed in accordance with ITLV-0425, "Measuring and Testing Equipment Calibration and Measurement," and ITLV-460, "Daily Source and Background Checks" (IT, 1993).

The CPT will be used to log gamma activity using the scintillation counter and to screen and measure VOC soil gas using a PID/FID and GC/MS. Logging of VOC information will be recorded through the vertical penetrometer push. During the CPT probe withdrawal, the probe may be halted to obtain a gamma spectral analysis. Specific locations for these analyses will be selected by the IT lead scientist. The gamma spectral analysis will be performed using the multichannel analyzer. Each penetration will be grouted to the topical elevation after the probe has been removed.

Data will be collected and compiled daily and copied onto electronic media. Field activity data will be controlled in accordance with ITLV-401, "Field Activities Documentation" (IT, 1993). The collected data will be subject to review and verification before they are used in the assessment of CAU 143. Concurrence from the IT lead scientist and project manager is required.

After logging the pertinent information and completion of in situ sampling, the CPT will be configured to collect soil samples. Soil samples for laboratory analysis will be collected from selected locations based on a minimum of 20 percent of the number of in situ sampling locations. The site supervisor and IT lead scientist shall choose the location and depth of these soil sample locations. Soil samples will also be used to obtain soil geotechnical data needed for corrective action design. 
The CPT using a screened section above the probe will be used for collecting soil/gas VOC data. An inert gas is used to purge the rod and transfer samples to the surface where a GC/MS will analyze the gas. The sample stream will be continuously analyzed with a PID or FID to determine existence of VOCs. Interstitial air samples will be collected at:

- The base of the cover material

- The base of the waste disposal unit

- $\quad$ Bottom of the CPT push

- Locations identified by a PID/FID detection 2.5 times background

The PID and FID will be calibrated regularly in accordance with Standard Quality Practice ITLV-0425, "Measuring and Testing Equipment Calibration and Measurement" (IT, 1993). The GC/MS will be calibrated in accordance with the manufacturer's instructions.

A module located in the CPT tip transports gas samples up to the surface during selected tests. Gas samples may be collected using either of the two following techniques.

- Individual soil gas samples from a specific soil profile or a specific suspected contaminated depth. Multilevel samples in a single push can be recovered without returning the cone to the surface.

- On-line soil gas measurements allow continuous monitoring using multi-gas monitor as the CPT is advanced. A GC/MS can then be used for a more detailed breakdown and analysis of the sample.

To ascertain potential contamination at a specific location, concentrations exceeding the screening levels will indicate potential contamination at that specific location. Background levels of COPCs will be established from a minimum of two CPT pushes located near but outside of the CAU waste areas. Corrective action for this site will be based on in situ measurements and confirmatory samples. The following screening levels will be used as a guide for the collection laboratory samples:

- Radiation (gamma) screening level is the mean background activity plus two (2) times the standard deviation of the mean background activity (Adams, 1998)

- $\quad$ VOC levels of 2.5 times background 


\section{A.6.0 Decision Rules}

The following decision rules will be used to guide the investigation and subsequent data evaluation.

- If during the course of the investigation, any of the following occur, then the investigation method will be reevaluated:

- The investigative method is inadequate.

- The conceptual site model fails.

- Sufficient data are collected to support evaluation of corrective actions.

- If the CPT meets refusal, the advancement will be terminated and moved to an adjacent location.

- After achieving the depth of $10 \mathrm{ft}$ below the bottom of the waste disposal areas, the advancement will be stopped and moved to the next CPT location.

- If, in determining the lateral extent of migration, a depth of $10 \mathrm{ft}$ beyond the point that readings are below background levels is obtained, the advancement will be stopped and moved to the next CPT location.

Table A.6-1 provides additional decision points. 
Table A.6-1

CAU Subsurface Specific Decision Points and Rules

\begin{tabular}{|c|c|c|}
\hline Decision Point & Decision Result & Decision Rule \\
\hline \multirow{3}{*}{$\begin{array}{l}\text { CAN WASTES BE } \\
\text { LOCATED AND } \\
\text { SURVEYED WITH CPT }\end{array}$} & Yes & $\begin{array}{l}\text { Proceed until } 10 \mathrm{ft} \text { beyond the point to which background } \\
\text { readings are obtained or } 10 \mathrm{ft} \text { below the waste disposal area }\end{array}$ \\
\hline & $\begin{array}{l}\text { Yes, but in a } \\
\text { different location }\end{array}$ & $\begin{array}{l}\text { Adjust investigation location based on evidence of actual } \\
\text { migration contaminant location; proceed until } 10 \mathrm{ft} \text { beyond the } \\
\text { point to which background readings are obtained or } 10 \mathrm{ft} \text { below } \\
\text { waste disposal area }\end{array}$ \\
\hline & No & The investigation will use rotosonic drilling \\
\hline \multirow{3}{*}{$\begin{array}{l}\text { CAN CPT REACH THE } \\
\text { LATERAL EXTENT OF } \\
\text { MIGRATION }\end{array}$} & Yes & $\begin{array}{l}\text { Proceed until lateral extent of migration is determined; go } \\
\text { laterally to } 10 \mathrm{ft} \text { beyond last indication of COPC }\end{array}$ \\
\hline & No & $\begin{array}{c}\text { Move to another CPT location and redo, proceed until lateral } \\
\text { extent of migration is determined }\end{array}$ \\
\hline & $\begin{array}{l}\text { No alternate CPT } \\
\text { location(s) cannot } \\
\text { define perimeter }\end{array}$ & The investigation will use rotosonic drilling \\
\hline \multirow{4}{*}{$\begin{array}{l}\text { CAN CPT REACH THE } \\
\text { VERTICAL EXTENT OF } \\
\text { CONTAMINATION } \\
\text { MIGRATION }\end{array}$} & Yes & $\begin{array}{l}\text { Proceed until } 10 \mathrm{ft} \text { beyond the point which background reading } \\
\text { are not obtained or } 10 \mathrm{ft} \text { below the waste disposal area }\end{array}$ \\
\hline & No, due to refusal & $\begin{array}{l}\text { Record data; move CPT location and sample again; proceed } \\
\text { until } 10 \mathrm{ft} \text { beyond the point to which background readings are } \\
\text { not obtained or } 10 \mathrm{ft} \text { below the waste disposal area }\end{array}$ \\
\hline & $\begin{array}{l}\text { No, alternate CPT } \\
\text { locations cannot } \\
\text { define extent }\end{array}$ & The investigation will use rotosonic drilling \\
\hline & $\begin{array}{l}\text { No, due to the } \\
\text { depth of } \\
\text { contamination } \\
\text { migration }\end{array}$ & The investigation will use rotosonic drilling \\
\hline
\end{tabular}




\section{A.7.0 Decision Error}

Biased locations will be selected for CPT pushes. The biased approach is appropriate because the locations of the waste disposal areas are relatively well known or can be reasonably assumed. Lithological data, soil gas information, and total gamma activity surveys will be conducted continuously. Surveying during each push will be conducted for gamma and soil gas analysis. This ensures the extent of the migration has been adequately located, quantified, and identified. 


\section{A.8.0 References}

Adams, Stephen R. (IT Corporation). 1998. Memo to Robert McCall regarding "Methodology for Determining Preliminary Action Levels for CAU 407, the Roller Coaster RADSAFE Area," 16 June. Las Vegas, NV.

DOE/NV, see U.S. Department of Energy, Nevada Operations Office.

EPA, see U.S. Environmental Protection Agency.

FFACO, see Federal Facility Agreement and Consent Order.

Federal Facility Agreement and Consent Order. 1996, as amended. Agreed to by the State of Nevada, the U.S. Department of Energy, and the U.S. Department of Defense.

Hale, G.S., and C.L. Westenburg. 1995. Selected Ground-Water Data for Yucca Mountain Region, Southern Nevada and Eastern California, Calendar Year 1993, Open-File Report 95-158. Carson City, NV.

IT, see IT Corporation.

IT Corporation. 1993, as amended. ITLV Program Procedures Manual, Standard Quality Practices. Las Vegas, NV.

NAC, see Nevada Administrative Code.

Nevada Administrative Code. 1998. NAC445A.226 - NAC445A.22755, "Corrective Action Regulations." Carson City, NV: Nevada Division of Environmental Protection.

U.S. Department of Energy, Nevada Operations Office. 1996b. Final Environmental Impact Statement for the Nevada Test Site and Off-Site Locations in the State of Nevada, DOE/EIS 0243. Las Vegas, NV.

U.S. Department of Energy, Nevada Operations Office. 1996a. Industrial Sites Quality Assurance Project Plan, Nevada Test Site, Nevada, Rev. 1, DOE/NV-372. Las Vegas, NV.

U.S. Environmental Protection Agency. 1998. Memorandum from S.J. Smucker to PRG table mailing list regarding Region IX Preliminary Remediation Goals, 1 August. San Francisco, CA.

Tinney, J.F. and Wheeler, D.L. 1999. Radiological Calculations for Corrective Action Unit 143: Area 25 Contaminated Waste Dumps, Nevada Test Site. Las Vegas, NV: U.S. Department of Energy, Nevada Operations Office. 
Appendix B

\section{Project Organization}




\section{B.1.0 Project Organization}

The DOE/NV Project Manager is Janet Appenzeller-Wing, (702) 295-0461. The identification of the Health and Safety Officer and the Quality Assurance Officer for this project can be found in the appropriate DOE/NV plan. However, personnel are subject to change, and it is suggested that the Project Manager be contacted for further information. The Task Manager will be identified in the FFACO Biweekly Activity Report prior to the start of field activities. 


\section{Appendix C}

\section{Historic Drawings}




\section{C.1.0 Historic Drawings For CWD \#1 and CWD \#2}

Figure C.1-1. U.S. Atomic Energy Commission. "MAD Dump Area Expansion Trestle Plan \& Profile," Drawing Number 400-002-C8J.

Figure C.1-2. "Proposed Addition to MAD BLDG,” Dump Area. Drawing Number J6-SK-J125.

Figure C.1-3. Los Alamos Scientific Laboratory. "Burial Pit R-MAD Hot Dump," Drawing Number J6-SK-JA-509.

Figure C.1-4. Space Nuclear Propulsion Office. "Radioactive Waste Disposal Area E-MAD," Drawing NRDS-SF-P33/C1. 


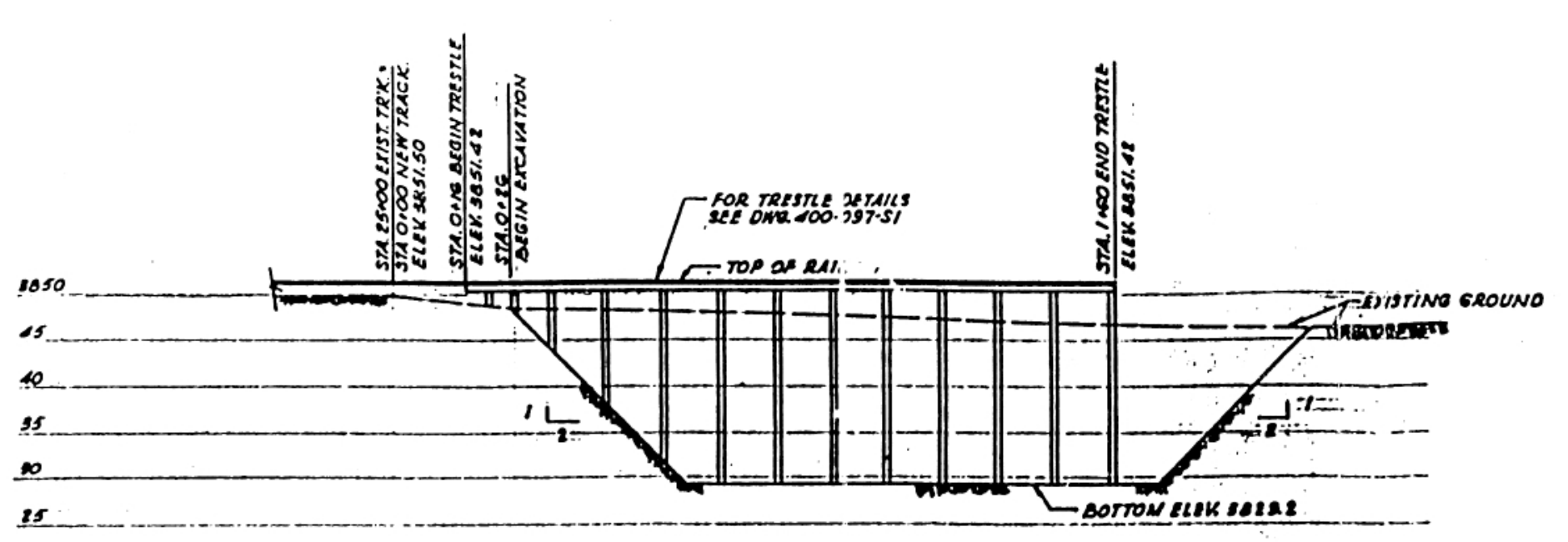

sacut

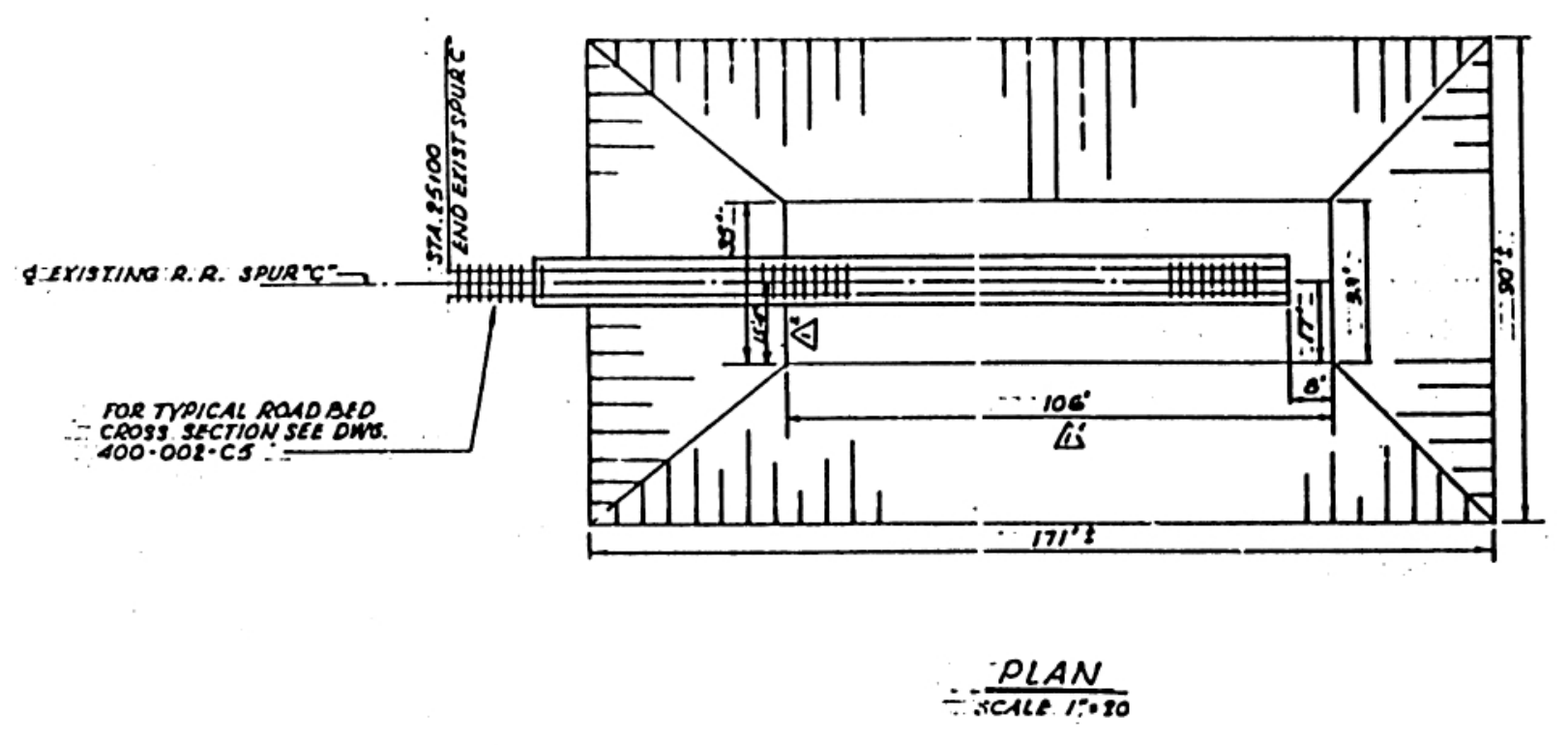

As-BUILI

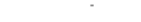
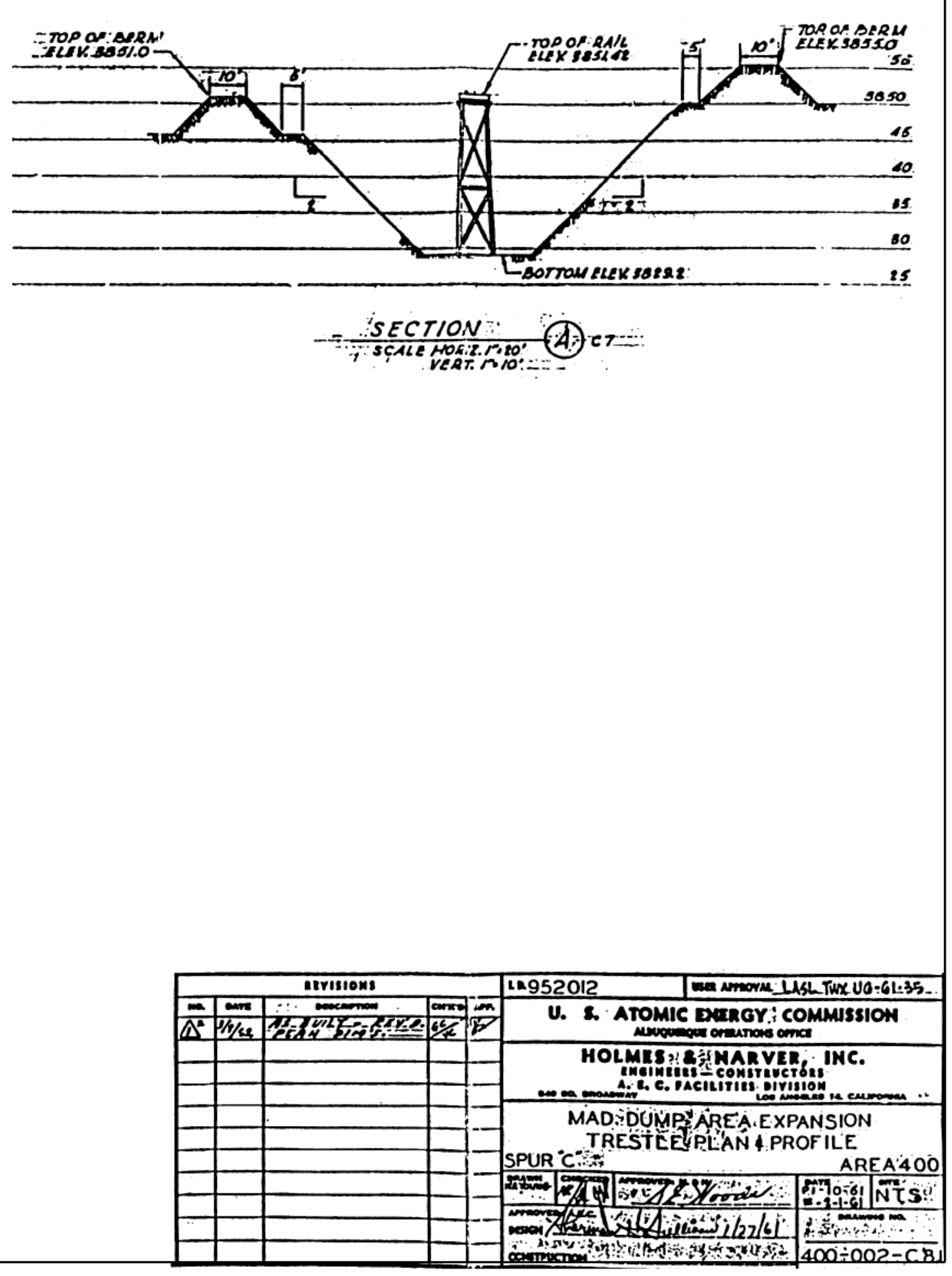


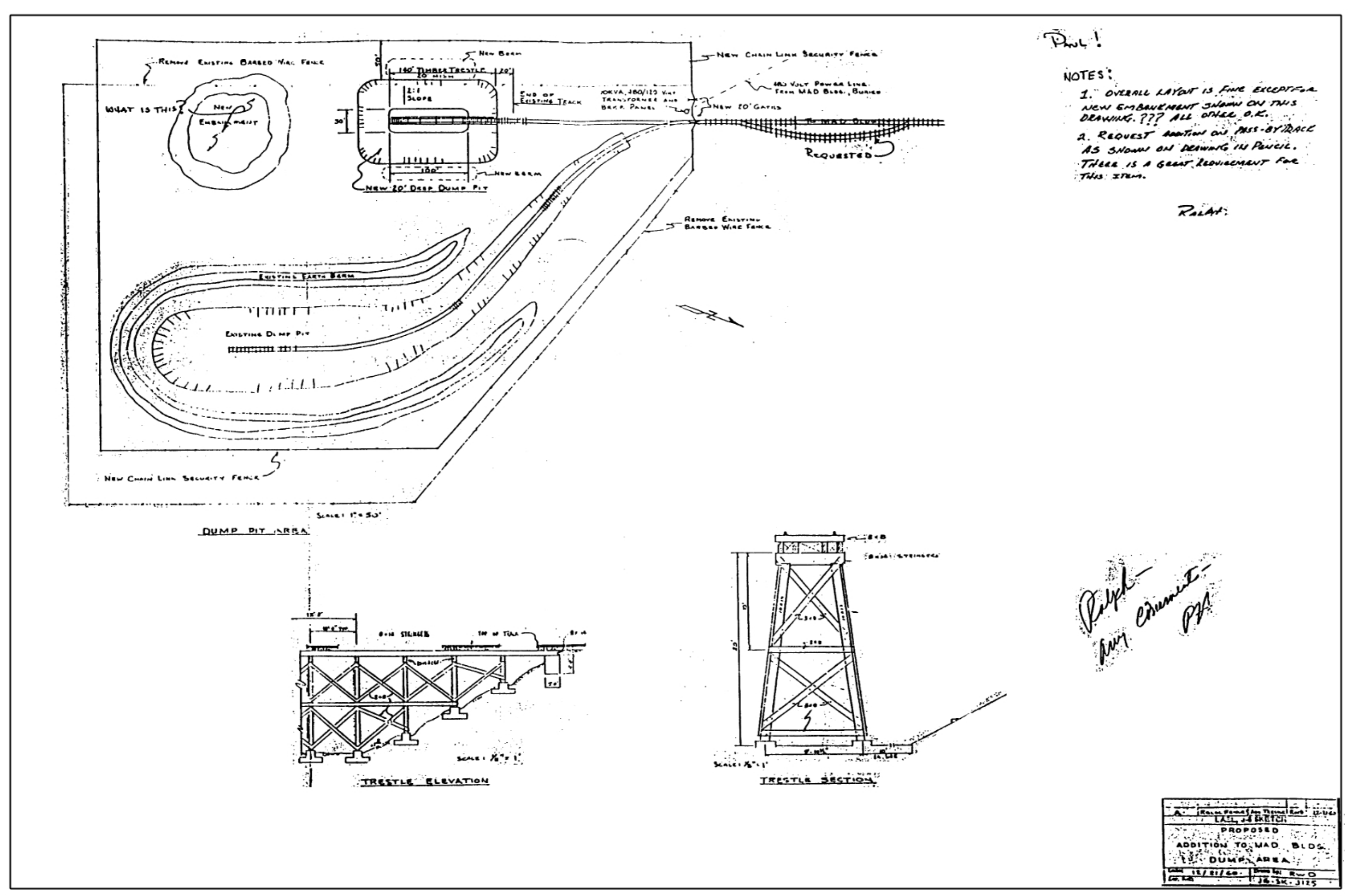

CAU 143 CAIP

Date: $06 / 28 / 99$
Page C-3 of C-5

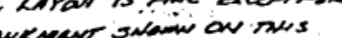
als anse a.k. 政

Rasas:

How ond Dio 


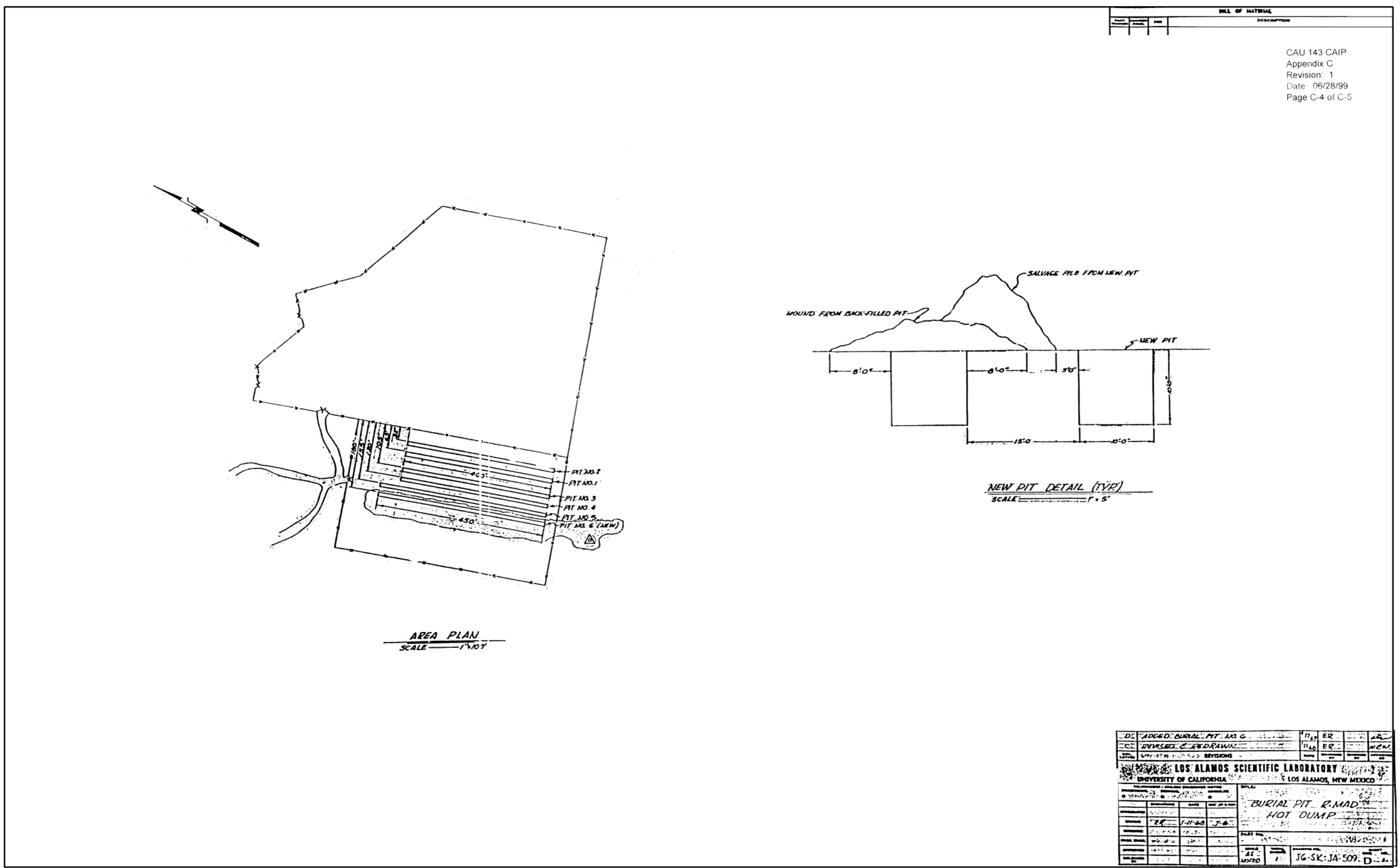




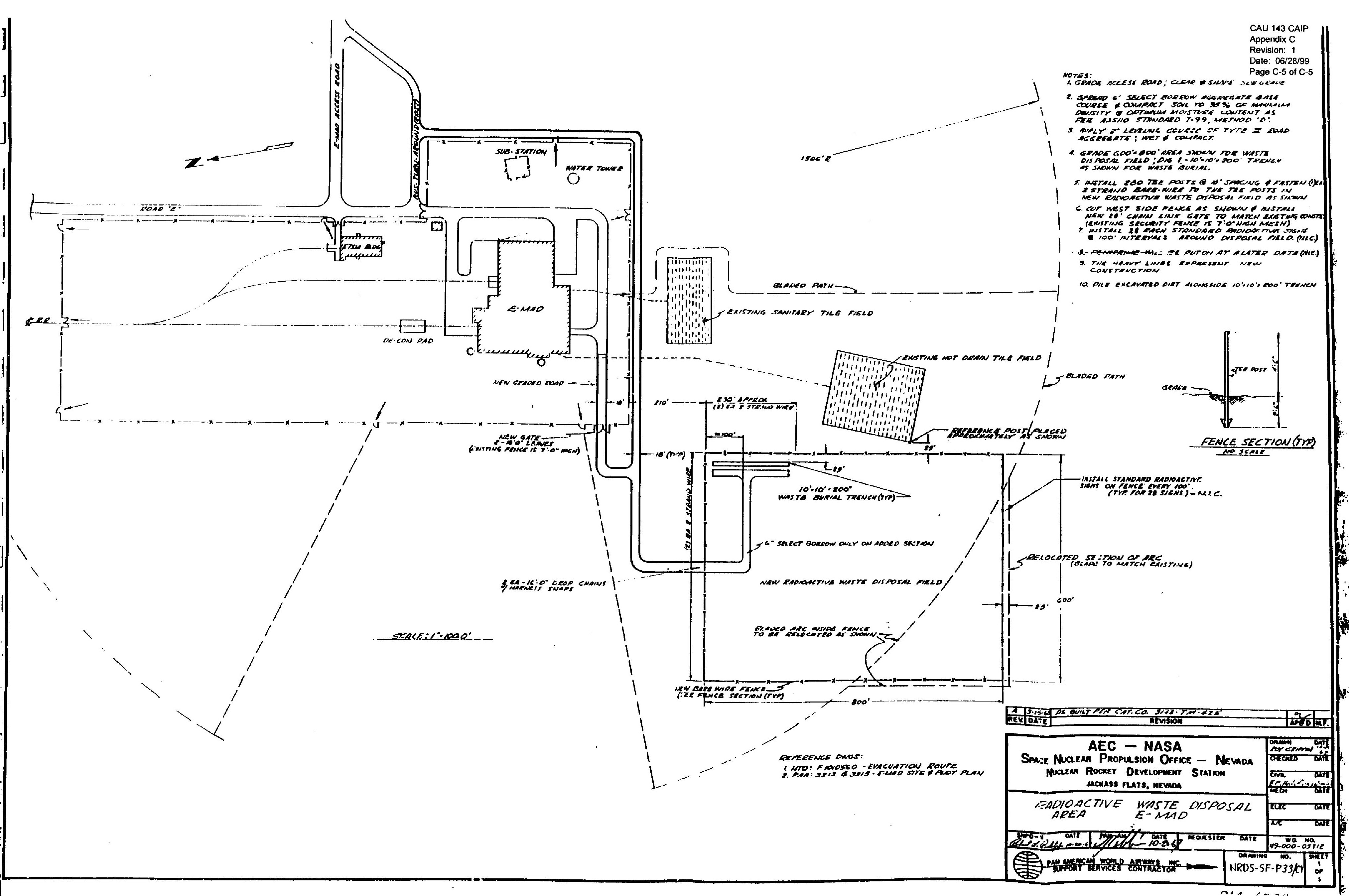




\section{Appendix D}

Response to

NDEP Comments 
NEVADA ENVIRONMENTAL RESTORATION PROJECT

DOCUMENT REVIEW SHEET

(Page 1 of 3 )

\begin{tabular}{|c|c|c|c|c|c|}
\hline \multicolumn{4}{|c|}{ 1. Document Title/Number: CAIP CAU 143, Area 25 CWDs } & \multicolumn{2}{|l|}{ 2. Document Date: June 1998} \\
\hline \multicolumn{4}{|c|}{ 3. Revision Number: 0} & \multicolumn{2}{|c|}{ 4. Originator/Organization: IT Corporation } \\
\hline \multicolumn{4}{|c|}{ 5. Responsible DOE/NV ERP Subproject Mgr.: Janet Appenzeller-Wing } & \multicolumn{2}{|c|}{ 6. Date Comments Due: June 24, 1999} \\
\hline \multicolumn{6}{|c|}{ 7. Review Criteria: Full } \\
\hline \multicolumn{4}{|c|}{ 8. Reviewer/Organization/Phone No.: Nevada Department of Environmental Protection } & \multicolumn{2}{|l|}{ 9. Reviewer's Signature: } \\
\hline $\begin{array}{l}\text { 10. Comment } \\
\text { Number/ } \\
\text { Location }\end{array}$ & 11. Type* & 12. Comment & \multicolumn{2}{|c|}{ 13. Comment Response } & 14. Accept \\
\hline $\begin{array}{l}\text { 1) CAIP, } \\
\text { Section 3.3, } \\
\text { Preliminary } \\
\text { Action Levels, } \\
\text { last bullet }\end{array}$ & & $\begin{array}{l}\text { Technical basis for assigning PALs for gross alpha concentrations } \\
\text { greater than } 12 \mathrm{pCi} / \mathrm{g} \text { and gross beta concentrations greater than } 18 \\
\mathrm{pCi} / \mathrm{g} \text { must be provided in the revised CAIP. }\end{array}$ & \multicolumn{2}{|c|}{$\begin{array}{l}\text { The PALs for radionuclides are isotope-specific and are } \\
\text { defined as the mean concentration plus } 2 \text { standard } \\
\text { deviations from the mean for each isotope found in } \\
\text { environmental samples taken from undisturbed background } \\
\text { locations. Environmental background samples will be taken } \\
\text { in the vicinity of CWD \#1 and CWD \#2. The data from these } \\
\text { samples will be compared to radionuclide concentrations } \\
\text { found in environmental samples taken from other } \\
\text { undisturbed background locations in Area } 25 \text { and as } \\
\text { presented in McArthur and Miller (1989) and Atlan-Tech } \\
\text { (1992). }\end{array}$} & \\
\hline $\begin{array}{l}\text { 2) Appendix D, } \\
\text { DOE reply to } \\
\text { NDEP } \\
\text { Comment } 3\end{array}$ & & $\begin{array}{l}\text { "...It is still agreed that gross alpha and gross beta analysis of } \\
\text { samples would be performed. If the gross alpha and gross beta } \\
\text { concentrations exceed the preliminary action levels (PALs), the } \\
\text { alpha spectroscopy and gamma spectroscopy would be performed } \\
\text { on the archived samples...' Gross alpha, gross beta and gamma } \\
\text { measurements must be performed on each field-screened sample. }\end{array}$ & \multicolumn{2}{|c|}{$\begin{array}{l}\text { Field analysis with the gamma spectrometer in the } \\
\text { CPT will provide the identity of the radioisotopes } \\
\text { emitting gamma radiation. Our knowledge of the } \\
\text { processes and materials deposited in the dump } \\
\text { indicates that alpha and beta emitters are always } \\
\text { associated with gamma emitters. Soil samples that } \\
\text { are taken for laboratory confirmation will be analyzed } \\
\text { for gross alpha and beta. }\end{array}$} & \\
\hline
\end{tabular}




\section{NEVADA ENVIRONMENTAL RESTORATION PROJECT}

DOCUMENT REVIEW SHEET

(Page 2 of 3 )

\begin{tabular}{|c|c|c|c|c|}
\hline $\begin{array}{l}\text { 10. Comment } \\
\text { Number/ } \\
\text { Location }\end{array}$ & 11. Type* & 12. Comment & 13. Comment Response & 14. Accep \\
\hline $\begin{array}{l}\text { 3) Appendix D, } \\
\text { DOE reply to } \\
\text { NDEP } \\
\text { Comment } 5\end{array}$ & & $\begin{array}{l}\text { The Nevada Administrative Code (NAC) which is referenced } \\
\text { (NAC 445A.345) is not "Corrective Action Regulations", but } \\
\text { "Definitions" under "Notification of Release of Pollutants". The } \\
\text { intended NACs are NAC 445A.226-NAC 445A.22755 (Action Levels } \\
\text { for Contaminated Sites) and must be clearly stated in the revised } \\
\text { CAIP. }\end{array}$ & $\begin{array}{l}\text { The reference for the "Corrective Action Regulations" has } \\
\text { been corrected to NAC 445A.226-NAC445.22755 in the } \\
\text { CAIP. }\end{array}$ & \\
\hline $\begin{array}{l}\text { 4) Appendix D, } \\
\text { DOE reply to } \\
\text { NDEP } \\
\text { Comment } 10\end{array}$ & & $\begin{array}{l}\text { "...Waste types will be determined from results of soil sampling from } \\
\text { the CAIP..." This statement is in conflict with paragraph } 5.3 .3, \text {, This } \\
\text { statement is in conflict with paragraph } 5.3 .3 \text {, "...Characterization will } \\
\text { be based on laboratory results from soil sampling..." Waste } \\
\text { Classification/characterization will be based on laboratory analysis } \\
\text { and must be specified in the revised CAIP. }\end{array}$ & $\begin{array}{l}\text { Waste, other than soil, is potentially contaminated waste } \\
\text { only by virtue of contact with potentially contaminated } \\
\text { media. Therefore, sampling and analysis of IDW, separate } \\
\text { from analysis of site characterization samples, will not be } \\
\text { required. The data generated as a result of field screening } \\
\text { and soil sampling during site characterization will be used to } \\
\text { assign the appropriate waste type to the IDW. The final } \\
\text { disposition of such wastes will be determined by evaluating } \\
\text { the analytical results of acquired soil samples. }\end{array}$ & \\
\hline $\begin{array}{l}\text { 5) PA, } \\
\text { Section 2.4.1, } \\
\text { Comments/ } \\
\text { Discussion }\end{array}$ & & $\begin{array}{l}\text { "...In both meetings, Mr. Lencioni stated that solutions of perchloric, } \\
\text { nitric and lor sulfuric acid and one-inch sections of fuel rods were } \\
\text { made for analysis. A small part of the mixture was used in the } \\
\text { analysis, and the remaining mixture was mixed with vermiculite, } \\
\text { placed into } 1 \text { or } 2 \text { liter bottles, and taken out to the dump. As much } \\
\text { as } 1,000 \text { liters of this solution may have been put in the dump..." } \\
\text { The dump referred to here is CWD 1, which is included in this CAIP. } \\
\text { This process may involve "Radioactive high level wastes generated } \\
\text { during the reprocessing of fuel rods" which is covered under } 40 \text { CFR } \\
268.40, \text { Subpart D, LDR Treatment Standards. The revised CAIP } \\
\text { must address whether the required treatment standard was met, } \\
\text { and if not, the proposed remedial action. }\end{array}$ & $\begin{array}{l}\text { The analysis of sections of the fuel rods was performed } \\
\text { immediately after the reactor run to assess the performance } \\
\text { of the core from the distribution of radioisotopes and } \\
\text { byproducts within the fuel elements. The one inch sections } \\
\text { of the rods that were dissolved for analysis represent } \\
\text { approximately } 1 / 50 \text { th of the fuel rod volume for a limited } \\
\text { number of fuel rods and for a period after these analyses } \\
\text { were transferred from LANL to R-MAD Jr. Hot Cell. The } \\
\text { remained of the fuel rods and fuel were sent to INEEL for } \\
\text { eventual reprocessing (Tinney and Wheeler, 1999). }\end{array}$ & \\
\hline
\end{tabular}




\section{NEVADA ENVIRONMENTAL RESTORATION PROJECT}

DOCUMENT REVIEW SHEET

(Page 3 of 3 )

\begin{tabular}{|c|c|c|c|c|}
\hline $\begin{array}{l}\text { 10. Comment } \\
\text { Number/ } \\
\text { Location }\end{array}$ & 11. Type* & 12. Comment & 13. Comment Response & 14. Accept \\
\hline $\begin{array}{l}\text { 6) PA, } \\
\text { Section 2.6.2, } \\
\text { Comments/ } \\
\text { Discussion, } \\
\text { 1st bullet }\end{array}$ & & $\begin{array}{l}\text { "...A spur off the main railroad line fed to a graveyard used to bury } \\
\text { radioactive test hardware..." Is this spur separate from the two } \\
\text { spurs (trestle area and depressed area) already addressed? If } \\
\text { different, this area must be located and characterized. }\end{array}$ & $\begin{array}{l}\text { The main rail line ran into the R-MAD building and } \\
\text { technically the line to the dump is a spur; the rail line into the } \\
\text { dump consists of one line which splits into the trestle line } \\
\text { (trestle area) and a second line that ends between the } \\
\text { berms (depressed area) where materials on rail cars was } \\
\text { temporarily stored to allow materials to cool after rocket } \\
\text { engine testing. }\end{array}$ & \\
\hline $\begin{array}{l}\text { 7) PA, } \\
\text { Section } 2.6 .2 \text {, } \\
\text { Comments/ } \\
\text { Discussion, } \\
3^{\text {rd }} \text { and } 4^{\text {th }} \text { bullets }\end{array}$ & & $\begin{array}{l}\text { "... The depressed section of track may have been built over a } \\
\text { disposal pit..." and "...The depressed section of track was re-routed } \\
\text { between } 1965 \text { and } 1969 . . . " \text { It is unclear whether this original } \\
\text { depressed section of track is included in the CWD } 1 \text { investigation } \\
\text { plan. This must be clarified in the revised CAIP. }\end{array}$ & $\begin{array}{l}\text { The southernmost end of the depressed track between the } \\
\text { berms was placed over a previously existing pit. There are } \\
\text { no records of waste being placed in this pit but it has been } \\
\text { targeted for investigation using the CPT. }\end{array}$ & \\
\hline $\begin{array}{l}\text { 8) PA } \\
\text { Attachment G-6, } \\
\text { Record of } \\
\text { Meeting }\end{array}$ & & $\begin{array}{l}\text { This meeting references the CALTP experiment wherein a rocket } \\
\text { was launched from a tower into a pit. This pit was also used for } \\
\text { disposal of the rocket propellant (perchlorate with aluminum flake). } \\
\text { The location of this pit must be specified in the revised CAIP if the pit } \\
\text { is part of the CWD } 1 \text {. If not part of the CWD } 1 \text {, it must be identified } \\
\text { as part of another CAU investigation. }\end{array}$ & $\begin{array}{l}\text { The CALTP rocket experiments were carried out from a } \\
\text { stand on the north side of the R-MAD building. The testing } \\
\text { conducted at this location concerned launch tests to } \\
\text { ascertain that the rocket would clear the tower and the } \\
\text { rockets were recovered from a pit approximately } 50 \text { feet } \\
\text { down-range. All these activities occurred north of the } \\
\text { R-MAD building and are clearly outside of CAU } 143 \text {. }\end{array}$ & \\
\hline
\end{tabular}

a Comment Types: $\mathrm{M}=$ Mandatory, $\mathrm{S}=$ Suggested.

Return Document Review Sheets to DOE/NV Environmental Restoration Division, Attn: QAC, M/S 505. 


\section{Distribution}

*Provide copy in distribution of Rev. 1 and subsequent revisions if applicable. Copies of only the NDEP-approved document will be distributed to others.

Paul J. Liebendorfer

State of Nevada

Bureau of Federal Facilities

Division of Environmental Protection

333 W. Nye Lane, Room 138

Carson City, NV 89706-0851

Michael McKinnon

State of Nevada

Bureau of Federal Facilities

Division of Environmental Protection

555 E. Washington, Suite 4300

Las Vegas, NV 89101

Sabrina Lawrence

Environmental Restoration Division

DOE/Nevada Operations Office

P.O. Box 98518, M/S 505

Las Vegas, NV 89193-8518

Janet Appenzeller-Wing

Environmental Restoration Division

DOE/Nevada Operations Office

P.O. Box 98518, M/S 505

Las Vegas, NV 89193-8518

Sabine Curtis

Environmental Restoration Division

DOE/Nevada Operations Office

P.O. Box 98518, M/S 505

Las Vegas, NV 89193-8518

Jeff Smith

Bechtel Nevada

P.O. Box 98521, M/S NTS306

Las Vegas, NV 89193-8521
2 (Controlled)*

1 (Controlled)*

1 (Controlled)*

1 (Uncontrolled)*

1 (Uncontrolled)*

1 (Uncontrolled)* 
Steve Nacht

Bechtel Nevada

P.O. Box 98521, M/S NTS306

Las Vegas, NV 89193-8521

Robert Eastmond

IT Corporation

P.O. Box 93838

Las Vegas, NV 89193

Mark DiStefano

IT Corporation

P.O. Box 93838

Las Vegas, NV 89193

IT Corporation Central Files

IT Corporation

P.O. Box 93838

Las Vegas, NV 89193

Technical Information Resource Center

DOE/Nevada Operations Office

P.O. Box 98518, M/S 505

Las Vegas, NV 89193-8518

U.S. Department of Energy

Office of Scientific and Technical Information

P.O. Box 62

Oak Ridge, TN 37831

Manager, Southern Nevada FFACO

Public Reading Room

P.O. Box 98521, M/S NLV040

Las Vegas, NV 89193-8521

Manager, Northern Nevada FFACO

Public Reading Room

c/o Rosa Silver

IT Corporation

P.O. Box 93838

Las Vegas, NV 89193
1 (Uncontrolled)*

1 (Uncontrolled)*

1 (Uncontrolled)*

1 (Uncontrolled)*

1 (Uncontrolled)

1 (Uncontrolled, electronic copy)

1 (Controlled)

1 (Uncontrolled)

1 (Uncontrolled) 
FFACO Public Reading Room Coordinator

1 (Controlled)

Rosa Silver

IT Corporation

P.O. Box 93838

Las Vegas, NV 89193 